FLOOD-CARRYING CAPACITIES AND CHANGES IN CHANNELS

OF THE LOWER PUYALLUP, WHITE, AND CARBON RIVERS

IN WESTERN WASHINGTON

By Edmund A. Prych

U.S. GEOLOGICAL SURVEY

Water-Resources Investigations Report 87-4129

Prepared in cooperation with the

STATE OF WASHINGTON DEPARTMENT OF ECOLOGY and PIERCE COUNTY PUBLIC WORKS DEPARTMENT 
DEPARTMENT OF THE INTERIOR

DONALD PAUL HODEL, Secretary

U.S. GEOLOGICAL SURVEY

Dallas L. Peck, Director

For additional information write to:

District Chief

U.S. Geological Survey

1201 Pacific Avenue - Suite 600

Tacoma, Washington 98402
Copies of this report

can be purchased from:

U.S. Geological Survey Books and Open-File Reports

Box 25425, Federal Center, B1dg. 810 Denver, Colorado 80225

Telephone (303) 236-7476 


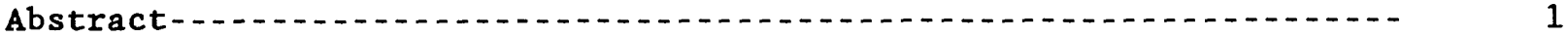

Introduction-

Background--

Purpose and scope-- 6

Methods - . -

Channel surveys---

Description of study area-

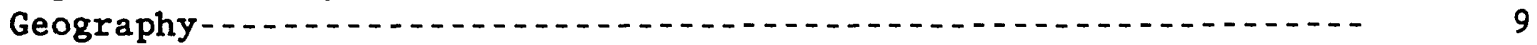

Description of channels-_-

Channel modifications, maintenance, and sediment removal-

General hydrology-....

Flow regulation-

Flood discharges - .

Flood-carrying capacities of 1984 channels-_.

Puyallup River-_.-. 19

White River-1.

Carbon River-...

Discussion--

Changes in channel and water-surface elevations-

Changes between 1974-77 and 1984-

Puyallup River-........ 28

White River-.... 28

Carbon River-... 33

Discussion- .

At gaging stations-

Puyallup River at Puyallup-......... 34

Puyallup River at Alderton- 37

Puyallup River near Orting-... 37

White River near Sumner- 38

Effects of streambank vegetation-

Summary and conclusions-1

References cited--

Appendix- 
FIGURE 1. Map of Puyallup River basin showing location of study area

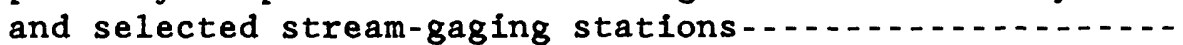

2. Graph of longitudinal streambed profiles along thalwegs of the lower Puyallup, White, and Carbon Rivers-....

3. Graph of peak annual discharges in Puyallup River at Puyallup, Wash., for water years 1915-86-..

4. Definition sketch showing method for computing average cross-section elevation at surveyed cross sections--..-

5-7. Graphs showing changes in average elevations of surveyed stream-channel cross sections and computed water-surface elevations for the 100 -year flood from:

5. 1976-77 to 1984 for the lower Puyallup River-..-.-

6. 1977 (Pierce County) or 1974 (King County) to

1984 for the lower White River-...

7. 1977 to 1984 for the lower Carbon River-.......

8. Graphs showing history of water-surface elevations corresponding to discharges exceeded 10 percent of the time at gaging stations on the Puyallup River at Puyallup, Puyallup River at Alderton, Puyallup River

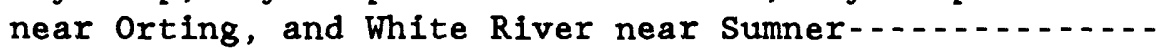

\section{APPENDEX ILLUSTRATIONS}

Al. Map of Puyallup River drainage basin showing areas included in panels of figure A2...

A2. Panels A through $K$. Maps of river reaches showing locations of surveyed cross sections-.......

A3-A5. Profiles of computed water-surface elevations for 10-, $50-$, and 100-year floods, and of tops of banks or levees along the 1984 channel of the lower:

A3. Puyallup River-...

A4. White River-...

A5. Carbon River-... 
TABLE 1. Volumes of sediment removed from Puyallup, White, and Carbon Rivers by Pierce County and Inter-County River Improvement in the years 1974 to 1985

2. Estimated flood-peak discharges for reaches of the lower Puyallup, White, and Carbon Rivers, and estimated coincident discharges in tributaries for use in computing water-surface profiles................

3-5. Flood-carrying capacities at cross sections surveyed in 1984 of the:

3. Lower Puyallup River channe1-.

4. Lower White River channe1-.... 24

5. Lower Carbon River channel-... 25

6. Estimated increases in values of effective Manning's roughness coefficient at cross sections and in computed water-surface elevations for 100-year floods in 1984 channels due to assumed increased density of streambed

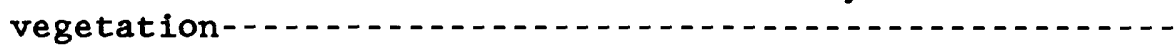

\section{APPENDIX TABLES}

A1-A3. Elevations for 1984 of tops of banks or levees, of thalwegs, and of computed water surfaces for floods of various magnitudes at cross sections of the:

Al. Lower Puyallup River.

A2. Lower White River-... 48

A3. Lower Carbon River-. 49

CONVERSION FACTORS

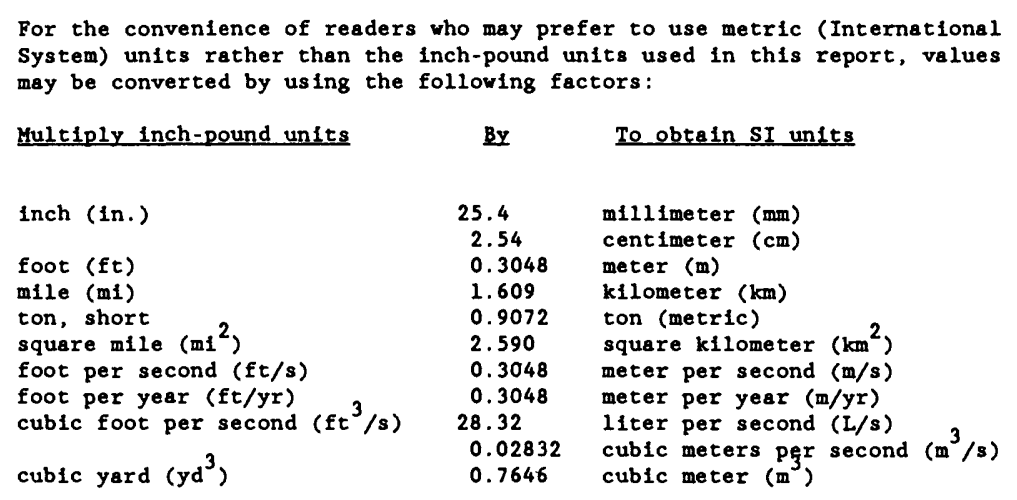

Sea level: In this report "sea level" refers to the National Geodetic

Vertical Datum of 1929 (NGVD of 1929)--a geodetic datum derived from a general adjustment of the first-order level nets of both the United Statea and Canada, formerly called "Mean Sea Level of 1929."

degree Fahrenhelt $\left({ }^{\circ} F\right)$ to degree Celsius $\left({ }^{\circ} C\right):{ }^{\circ} C=5 / 9\left({ }^{\circ}-32\right)$ 


\title{
FLOOD-CARRYING CAPACITIES AND CHANGES IN CHANNELS OF THE LOWER PUYALLUP, WHITE, AND CARBON RIVERS IN WESTERN WASHINGTON
}

By Edmund A. Prych

\begin{abstract}
The flood-carrying capacity of a river channel at a cross section was defined in this study as the discharge for which the computed elevation of the water surface equals the surveyed elevation at the top of the riverbank, or in the case of a raised levee, 3 feet below the top of the levee. In the reach of the Puyallup River from its mouth to the city of Puyallup, the flood-carrying capacity equals or exceeds the 100 -year-flood discharge at all but a few locations. Even at these locations there is 2 to 3 feet of freeboard for the 100-year flood at all but one location. In the reach of the Puyallup River between the city of Puyallup and the stream-gaging station upstream from Orting, the flood-carrying capacity is less than the 100 -year flood at many locations. At some places, near the city of orting for example, computed 100-year-flood elevations are above the tops of levees.

The flood-carrying capacity of the White River channel in Pierce County is less than the 100-year flood at numerous locations. In King county the floodcarrying capacity of the White River channel would be greater than the 100-year flood nearly everywhere if it were not for washed-out sections of the left-bank levee at a number of locations upstream of the $R$ Street bridge at Auburn.

Because of these washed-out sections, the river inundates areas on the landward side of the levee nearly every year.

The flood-carrying capacity of the Carbon River is less than the 100-year flood at numerous locations. A 100 -year flood would overtop the levees near its mouth and near the mouth of South Prairie Creek.

Changes between 1976-77 and 1984 in average elevations of channe1 cross sections in the lower 26 miles of the Puyallup River were less than 1 foot at more than one-half of 70 surveyed cross sections and were more than 2 feet at only three of them. The estimated accuracy of these computed changes is in the range of 1 to 2 feet. Average elevation changes in the lower 6 miles of the Carbon River were less than 1 foot at more than one-half of 20 cross sections and were greater than 2 feet at only two of them.
\end{abstract}

Between 1977 and 1984 average cross-section elevations of the White River in the 4 miles between the river's mouth and the inflow from Lake Tapps rose about 2 feet or more at 5 of the 10 surveyed cross sections in this reach. Average channel elevations in the 7-mile-long reach upstream from the Lake 
Tapps inflow (mostly for the perfod 1974 to 1984) decreased 2 feet or more at more than one-third of the 29 surveyed cross sections. Lowering of the channel in this reach may have resulted from removal of gravel by contractors.

Differences between water-surface elevations for 100-year floods, computed using cross-section data from 1984 and 1974-to-1977 surveys, are similar in direction and magnitude to the changes in average cross-section elevations. Differences for the 10 - and 50-year floods are within 0.5 foot of those for the 100-year floods.

In the period between the surveys of the river cross sections, Pferce County and Inter-County River Improvement and private contractors removed more than a sufficient volume of sediment from the river channels to lower all channels in the study areas by 0.4 foot. If this sediment had not been removed larger increases in channel and 100-year-flood elevations might have occurred at some cross sections.

The magnitudes of possible increases in water-surface elevations for 100year floods that could be caused by dense growths of streambank vegetation were estimated to be from 0.7 to 1.2 feet in the Puyallup River between its mouth and the mouth of the Carbon River, and 0.2 to 0.6 foot upstream of the Carbon River. The estimated possible increase for the entire study reach of the Carbon River and for the White River upstream from the gage near Sumner is equal to or less than 0.2 foot. The possible increase on the white River downstream from the gage is 0.5 to 0.9 foot. 


\section{INTRODUCTION}

\section{Background}

The main streams in the lower Puyallup River basin are the Puyallup River and its two largest tributaries, the White and Carbon Rivers (fig. 1). Much of the land adjacent to these rivers and in their flood plains is developed, and additional development is expected. Typical forms of development include traditional single-family residences, mobile homes on individual lots, mobile home parks, cultivated land and farm buildings, and, to a lesser extent, commercial structures.

Existing flood-protection structures in the lower Puyallup River basin include raised levees and armored banks along much of the lengths of all three rivers, and a flood-storage reservoir behind Mud Mountain Dam on the White River (fig. 1). In spite of these flood-protection works, floods with average recurrence intervals as 1 ittle as 20 years (about $40,000 \mathrm{ft}^{3} / \mathrm{s}$ in the Puyallup River at Puyallup) have inundated developed property along some reaches.

Some people believe that inundation is more frequent now than in the past and have suggested two possible causes. One is that the river channel bottoms between the dikes or banks are aggrading with sediment and, consequently, causing a reduction in flood-carrying capacities of the channels. The other suggestion is that bushes and trees growing on the channel sides have increased the hydraulic roughness of the channels, thereby reducing their flood-carrying capacities.

Maintenance of flood-carrying capacities of the river channels is the responsibility of three different government agencies. The U.S. Army Corps of Engineers maintains about 3 miles of the Puyallup River channel from near its mouth to the city of Tacoma boundary (Appendix A, fig. A2 panel A). The Corps of Engineers also operates Mud Mountain Dam on the White River. Inter-County River Improvement (ICRI) maintains the Puyallup River channel from the Tacoma boundary upstream to a point 2,000 feet upstream of the confluence of the White River, and the channel of the White River from its mouth upstream some unspecified distance that is generally assumed to extend about 5 miles upstream of the city of Auburn (fig. 1). This agency, formed in 1914 after an act of the State legislature in 1913, is administered by the Pierce County Public Works Department, but operates in both Pierce and King Counties. Maintenance of the channel of the Carbon River and the remainder of the Puyallup River is the responsibility of Pierce County River Improvement (PCRI). This agency, formed in 1908, is also administered by Plerce County Public Works Department. Most of the recent work of these agencies has consisted of making repairs to maintain the structural integrity of the levees and riprapped banks and attempting to maintain the flood-carrying capacities of the channels by removing tops of above-water gravel bars and by removing trees and bushes from streambanks. However, these activities have met with disapproval from various groups wishing to maintain a suitable habitat in the rivers for the migration, spawning, and rearing of salmon and steelhead trout. These groups include the Puyallup and Muckelshoot Indian Tribes, the State of Washington Department of Game and Department of Fisheries, and the U.S. Fish and Wildlife Service. 


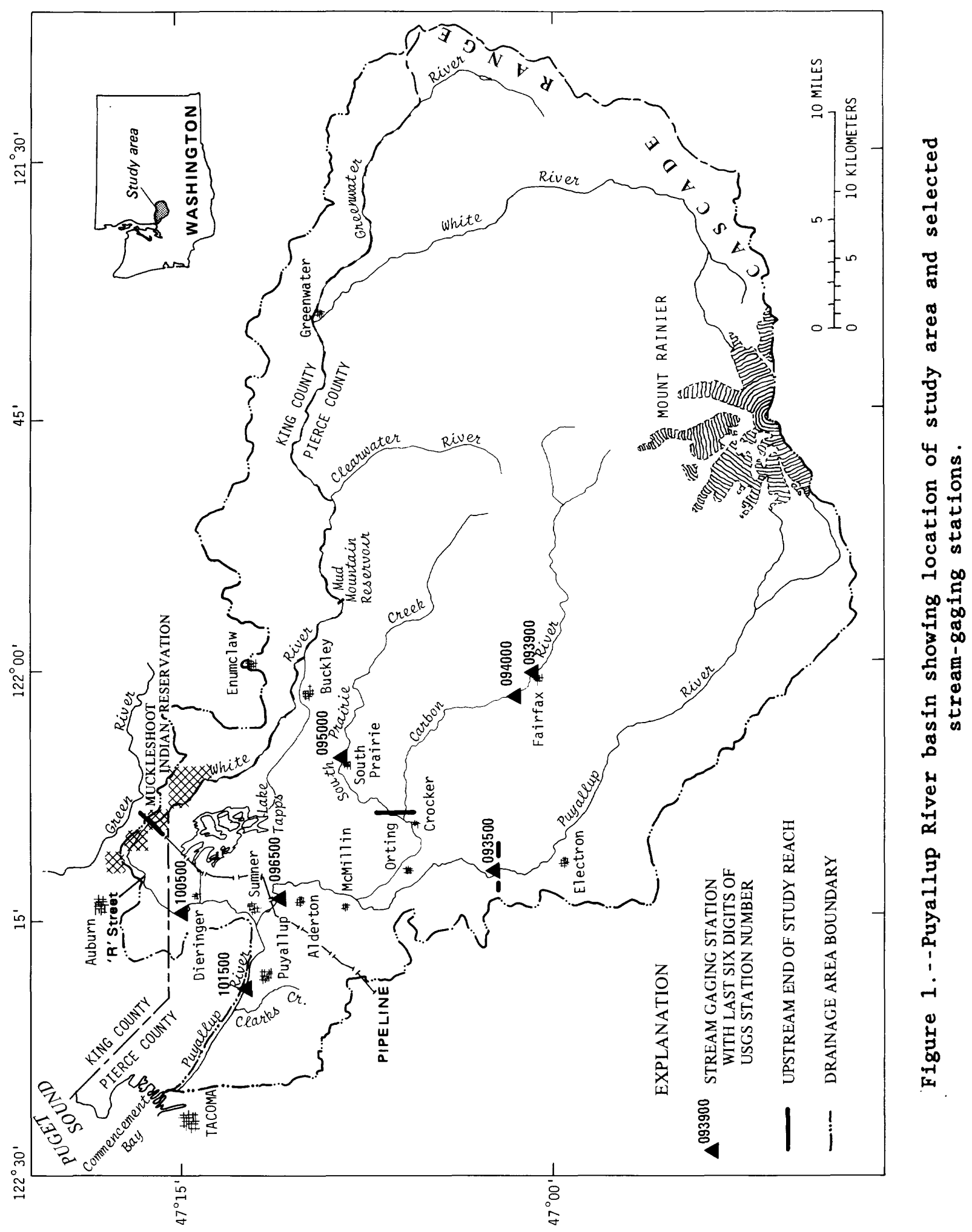


Because of the conflict between the apparent needs for flood protection and preservation of fish habitat, the Pierce County Public Works Department in 1983 initiated discussions to begin a study of the lower Puyallup River basin. The purpose of the study was to investigate ways for maintaining and improving flood protection and yet maintain or improve fish habitat. The study was to exclude new flood-storage reservoirs from consideration, but was to include all other viable means for providing flood protection. Investigations started in June 1984 with parts to be conducted by the U.S. Geological Survey, the U.S. Army Corps of Engineers, and the Pierce County Public Works Department, giving due consideration to the advice of fish habitat specialists from the fisheries groups with interests in the Puyallup basin. Part way through the study the State of Washington Department of Fisheries took the responsibility for conducting a part of the investigation. The specific goals of the overall study, and the agencies with primary responsibility are:

1) To obtain information on present and past flood-carrying capacities of the river channels (U.S. Geological Survey).

2) To estimate the amounts that levees would need to be raised or that channels would have to be dredged to attain desired flood-carrying capacities of river channels (U.S. Geological Survey).

3) To estimate the effects of streambank vegetation on water-surface elevations during floods (U.S. Geological Survey).

4) To make preliminary designs and evaluate the economics of levees, dredging, and other methods for reducing flood damage in the basin (U.S. Army Corps of Engineers).

5) To obtain hydraulic information on the present fish habitat in the river channels (U.S. Geological survey) and to estimate the effects of flood-protection methods on fish habitat (State of Washington Department of Fisheries).

6) To obtain information on sediment deposition, scour, and movement in the river channels, and attempt to estimate the effects of floodcontrol methods on sedimentation, and the effects of sedimentation on flood-control methods and on fish habitat (U.S. Geological Survey).

7) To evaluate the legality of the various structural and non-structural methods of flood protection in the basin (Pierce County Public Works Department).

8) To appraise the conjunctional effects on fish habitat and economics of the various methods, for potential application in the basin (Pierce County Public Works Department). 


\section{Purpose and Scope}

This report presents the results of some parts of the study that are the responsibility of the U.S. Geological Survey. Included are:

(1) Calculated flood-carrying capacities of the river channels as surveyed in 1984; computed water-surface profiles for floods with recurrence intervals of 2 to 100 years in 1984 channels; and differences between computed water-surface elevations for 100-year flood in 1984 channels and in 1974-77 channels. (for goal 1)

(2) estimates of possible effects of streambank vegetation on water-surface elevations during a 100-year flood. (for goal 3)

(3) differences between 1984 average cross-section elevations and average cross-section elevations in 1974-77; and long-term histories (up to 71 years) of water-surface elevations corresponding to particular discharges at four gaging stations in the study area. (for part of goal 6)

\section{Methods}

This section gives a brief description of the methods used to obtain reported results. More detailed descriptions on the various methods are given in the sections where the results are given.

Flood-carrying capacities of the river channels at cross sections spaced about 2,000 feet apart were obtained by comparing surveyed elevations of the tops of banks or levees with computed water-surface elevations for a range of discharges in the 1984 channels. Differences between 100-year-flood watersurface elevations in channels as they existed in 1984 and in 1974-77 were obtained by computing two sets of water-surface elevations using cross-section geometry data from surveys made at the two different times. All computed water-surface profiles used in this study were obtained by numerically solving the steady-state one-dimensional equation of motion for open-channel flow (the so-called step-backwater technique) (Shearman, 1976). Only one set of hydraulic roughness coefficients was used in this study. These coefficients were obtained by calibration using cross-section geometry data from the 1974-77 surveys and water-surface elevations during high water events in 1974 or 1977. The original project plans included obtaining hydraulic roughness coefficients for 1984 channels by using data to be collected during a high-water event in the winter of 1984-85. However, an event suitable for this purpose did not occur during that winter.

The possible effects that a dense growth of streambank vegetation could have on water-surface elevations during floods were estimated by approximating the possible increases in channel roughness that could be caused by vegetation, and comparing computed water-surface profiles for the 100-year flood with and without the increases in roughness.

Temporal changes in channel elevations were obtained in two ways. In the first method, the net changes in average channel elevation at each of 132 surveyed cross sections during the time between the older and recent surveys (1974-77 and 1984) were used to identify river reaches that aggraded or 
deepened during this period. The second method provided a longer and more detailed history of the year-to-year variation in channel elevation at four stream-gaging stations in the study area. With this method water-surface elevations corresponding to a discharge equal to the daily mean discharge that is exceeded 10 percent of the time were plotted as functions of time. The periods spanned by these data ranged from about 30 to 70 years. An increase or decrease in these concordant elevations is indicative of an increase or decrease, respectively, of the channel elevation in the reach downstream of the gage.

\section{Channel Surveys}

The computations of water-surface elevations during floods and of average elevations of channel cross sections require data on ground and streambed elevations at stream cross sections. Furthermore, two sets of these data, collected at different times, are required to estimate temporal changes in flood profiles or in cross-section elevations. The computations in this study utilized data from surveys conducted in the summer of 1984, which were made as part of this study, and from two previous surveys, one in 1974 or the other in 1976-77. Both of these earlier surveys were made for flood insurance studies for the Federal Emergency Management Agency (FEMA).

The 1976-77 survey covered all the river reaches in Plerce County, and the 1974 survey covered the reach of the White River in King County. In the 197677 survey, ground elevations and horizontal distances on the flood plains and on the channel banks were obtained for the U.S. Geological Survey by a private contractor using aerial photogrammetry. U.S. Geological Survey personnel obtained streambed elevations at each cross section by measuring water depths with a rod while wading, or from a boat. Differences between stream-surface elevations at the times of the photography and the depth surveys were estimated from water-level measurements made at bridges during the photography and depth surveys. The accuracy of these ground and streambed elevations is determined by the accuracy of the photogrammetry and is of the order of 1 foot. Lateral distances in the cross sections during the underwater survey were estimated and corrected with data from the photogrammetric survey. Typical distances between cross sections in the 1976-77 survey were about 1,000 feet. This survey was completed before the large December 1977 flood.

Data from the 1974 survey of the White River in King County were furnished by the U.S. Army Corps of Engineers (George Ristau, written commun., 1984). A private contractor obtained these data using photogrammetry and river-channel surveys. The accuracy of this survey is unknown, but is probably equal to or better than the accuracy of the 1977 survey. Distances between cross sections in this survey averaged about 500 feet.

In 1984, approximately one-half of the cross sections that were surveyed in 1974 and 1976-77 were resurveyed (usually every other one). The locations of these cross sections are shown in figure A2 of the appendix. These cross sections were located in the fleld as close to the cross sections surveyed in 1974-77 as could be determined from location markings on aerlal photographs. To afd in locating these cross sections in the future, two reference marks (usually plastic-capped steel rods) were placed on one side of the river at each cross section. 
In the 1984 survey only the parts of the cross sections below the tops of channel banks or levees were resurveyed. This work was performed entirely by U.S. Geological Survey personnel. Stadia and levels were used to define the geometry of the cross sections above water and in the shallow parts that could be waded. The deeper underwater parts were surveyed by stadia and a boat with a recording fathometer.

Vertical control for the 1984 survey was established to third order accuracy by levels to reference markers at all of the cross sections. While conducting the level survey, elevations of the tops of the levees or natural banks were obtained at many intermediate points between cross sections on one and sometimes both sides of the rivers. The accuracy of ground and streambed elevations determined in this survey was of the order of 0.2 foot.

Datum for these surveys and all elevations used in this report is the National Geodetic Vertical Datum of 1929 (NGVD of 1929). 


\section{DESCRIPTION OF STUDY AREA}

\section{Geography}

The river channels studied in this investigation are in the lower reaches of the Puyallup River and its two main tributaries, the White and Carbon Rivers (see fig. 1). These three rivers and their tributaries drain about 1,000 square miles of western Washington between Puget Sound and the crest of the Cascade Range.

The study reaches of the rivers lie in the Puget Sound lowland and extend from at or near their respective mouths to the foothills of the Cascades. About 80 percent of the total area of the drainage basin lies upstream of the upper ends of the study reaches. The upstream end of the study reach on the Puyallup River is near a stream-gaging station a few miles upstream from the city of Orting, about 26 miles from the river's mouth. The upstream end of the White River reach is near a gas pipeline crossing that is about 5 miles upstream from the Pierce-King County boundary and is about 10 miles upstream from the river's mouth. The upstream end of the study reach on the Carbon River is about 6 miles from its mouth and is about 1,000 feet upstream from the mouth of South Prairie Creek.

The White River between Auburn and the Puyallup River was and is sometimes still called the Stuck River. Before 1906 the discharge of the White River sometimes flowed north from the city of Auburn to the Green River, sometimes flowed south to the Puyallup River, and sometimes divided and flowed in both directions. During the first part of 1906 most of the water flowed north; however, channel erosion during a flood in November of that year shifted most of the discharge from the north to the south channel (Inter-County River Improvement Commission, 1936). In 1914, a concrete dam was constructed across the north channel at Auburn, and all the discharge of the White River has flowed in the south channel to the Puyallup River ever since.

\section{Descriptions of Channels}

Levees or training structures form the banks on one or both sides of the rivers along most of the study reaches. Rock riprap protect these structures and natural banks from erosion in most places. The higher parts of the levees along the Puyallup River between Tacoma and Puyallup and the banks of sections of the White River between its mouth and Auburn are paved with concrete. Most of the levees are kept in an adequate state of repair except for the one on the left bank of the White River upstream from Auburn on the Muckleshoot Indian Reservation (Appendix A, panels $I$ and $J$ fig. A2). On a number of days during high flow in June 1984, hundreds of cubic feet per second were observed flowing through gaps in this levee. This levee is being allowed to deteriorate at the request of the Muckleshoot Tribe.

Widths between the levees or banks range from greater than 1,000 feet to less than 150 feet. Along most of the Puyallup River, and along the White River downstream from Auburn, the streams occupy most of the width between banks, even at low to medium discharges. However, in the White River upstream of Auburn, in most of the Carbon River, and in some reaches of the Puyallup River upstream of the Carbon River, the water-surface width at low to medium 
flows is much less than the distance between the levees and, the stream is braided with numerous meander channels and islands between the levees or banks.

Streambed elevations in the study reaches range from a few feet below sea level near the mouth of the Puyallup River at Commencement Bay to about 350 feet above sea level at the gage on the Puyallup River near Orting (fig. 2). Land-surface altitudes in the basin extend up to 14,410 feet on Mount Rainier. Stream slopes tend to decrease in the downstream direction. Slopes range from approximately $0.010 \mathrm{ft} / \mathrm{ft}$ near the upstream ends of the reaches on the Puyallup and Carbon Rivers to about $0.001 \mathrm{ft} / \mathrm{ft}$ near the mouth of the Puyallup River, and down to less than $0.0005 \mathrm{ft} / \mathrm{ft}$ on the White River near its mouth.

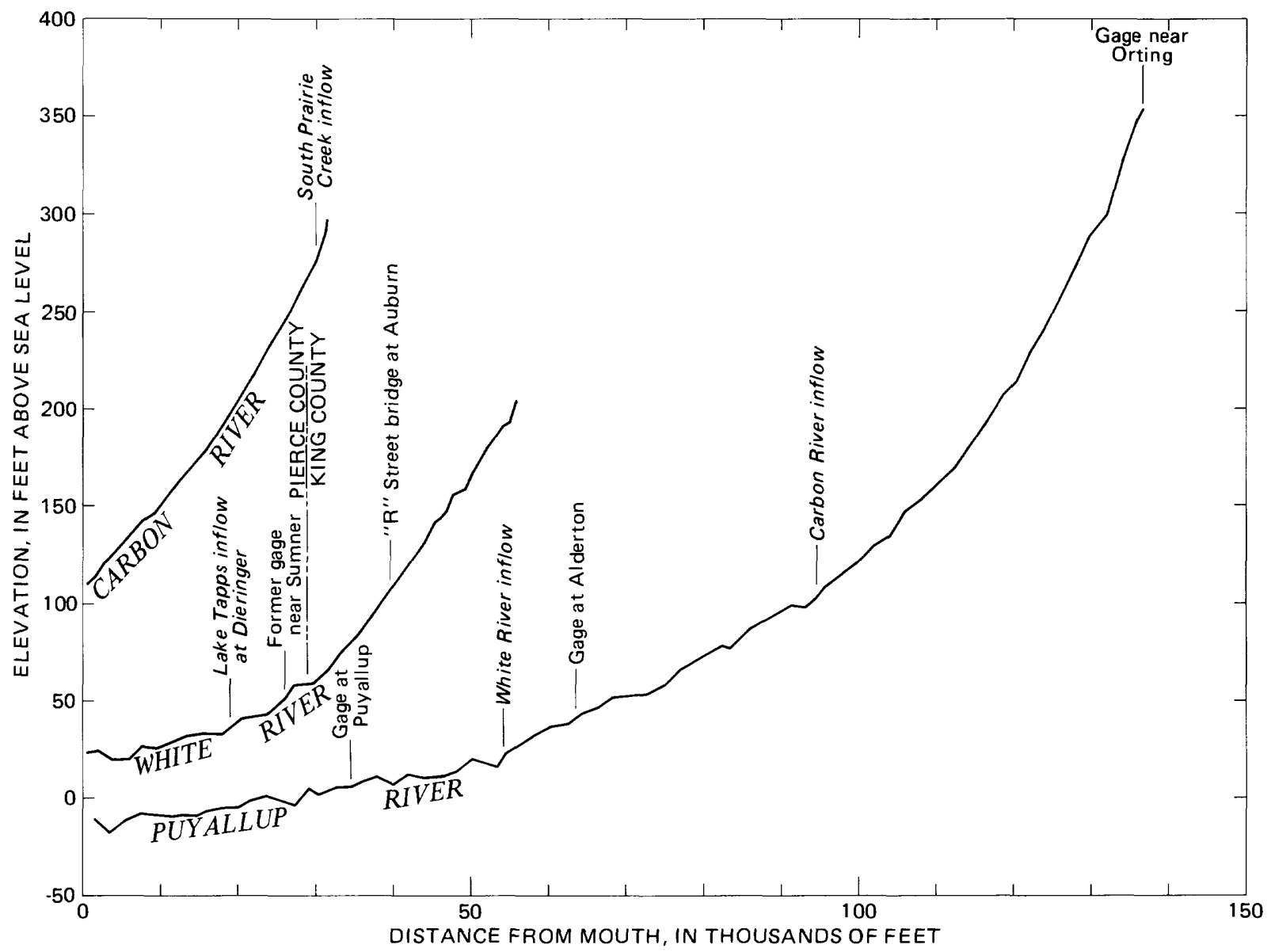

Figure 2.--Longitudinal streambed profiles along thalwegs of the lower Puyallup, White, and Carbon Rivers. (Data from 1984 survey.) 
Gravel, cobbles, and boulders armor the river bottoms in nearly all the study areas. Median particle sizes appear to decrease in the downstream direction. Material beneath the armor layer contains approximately 20-percent sand. Gravel bars abound in the Carbon River, the reach of the Puyallup River upstream from the White River, and in the White River upstream of the inflow from Lake Tapps. Grave1 bars exist, but are less numerous in the downstream reaches of the White and the Puyallup Rivers. Although sand deposits exist in local pockets and along some banks, sand predominates on the river bottom only in the downstream 2 or 3 miles of the Puyallup River where the flow is affected by tides in Puget Sound.

Vegetation grows on most streambanks including those with levees. The most common woody streambank vegetation is the rhizomatous willow, which commonly grows in clumps of 10 or more stems, each 4 inches or less in diameter; and red alder and cottonwood, which often grow in clumps of 4 or less with trunks that can grow to exceed 6 inches in diameter in 6 years and eventually exceed 16 inches in diameter (Tom Deming, fisheries biologist, Puyallup Tribe of Indians, oral commun., 1985). Common non-woody vegetation include grasses and dense patches of blackberry vines that often intermingle with willows and alder.

\section{Channel Modifications, Maintenance, and Sediment Removal}

Major modifications to the channels of the White River and the Puyallup River downstream of its confluence with the White River were made in the 5 years following the formation of ICRI (1914). During this period the agency conducted an active construction program in which it (1) constructed the diversion dam at Auburn to prevent the White River from flowing northward into the Green River, (2) constructed a drift barrier on the White River upstream of Auburn to trap floating debris, (3) developed the White (Stuck) River channel from Auburn to the Puyallup River, (4) straightened the Puyallup River channel from Sumner (near the confluence of the White River) to Tacoma (near the mouth), and (5) constructed levees and armored the banks along much of the newly constructed channels. ICRI continued with levee construction, channel realignment and bank armoring, but at a reduced rate, until about 1955. Since that time most of the work done by this agency has been repair and maintenance. PCRI realigned channels, constructed levees, and protected banks from erosion along most of the river reaches for which they have responsibility (the Carbon River and most of the Puyallup River upstream of the White River). This agency had an active construction program over most of the period from its formation (1908) through the 1960's. Since the early 1970's much of the agency's work, like that of the ICRI, has been limited to repair and maintenance. This work generally has consisted of repairing damaged sections of levees, removing gravel bars when they appear to be reducing the cross-sectional areas or increasing the average bottom elevations of the channels enough to seriously affect flood-carrying capacity, and cutting vegetation from streambanks and levees when it appears to seriously affect the channel roughness or structural integrity of the levees. Locations where gravel bars have been removed are numerous and are scattered throughout the study area. 
Volumes of sediment removed from the Puyallup River basin by PCRI and ICRI during the years 1974 to 1985 are given in table 1 . The sediment removed is mostly gravel and larger sizes. These volumes include material removed under contract as well as by the agencies' own work crews, and also material taken from the White River in 1975 and 1976 by the Washington Department of Transportation for use in highway construction. Most of the gravel-bar removal areas in the Puyallup River were in the reach between the confluence of the White River and the upstream end of the study area at the gage upstream of orting. Most of the removal areas in the White River were in the areas between the Lake Tapps outflow at Dieringer and the gas pipeline crossing upstream of Auburn. Most of the material removed from the Carbon River was from either a $1.5-\mathrm{mile-}$ long reach at its mouth or a reach extending 1.5 miles upstream from South Prairie Creek.

During 1974 to 1985 , about 2.1 million cubic yards of material were removed. This is equivalent to deepening the 42 miles of approximately $300-$ foot-wide channels in the study reaches 0.9 foot. The volume removed during 1978 through 1983, which is the period between the 1976-77 and 1984 crosssection surveys, was 0.87 million cubic yards. This is equivalent to a 0.4 foot deepening.

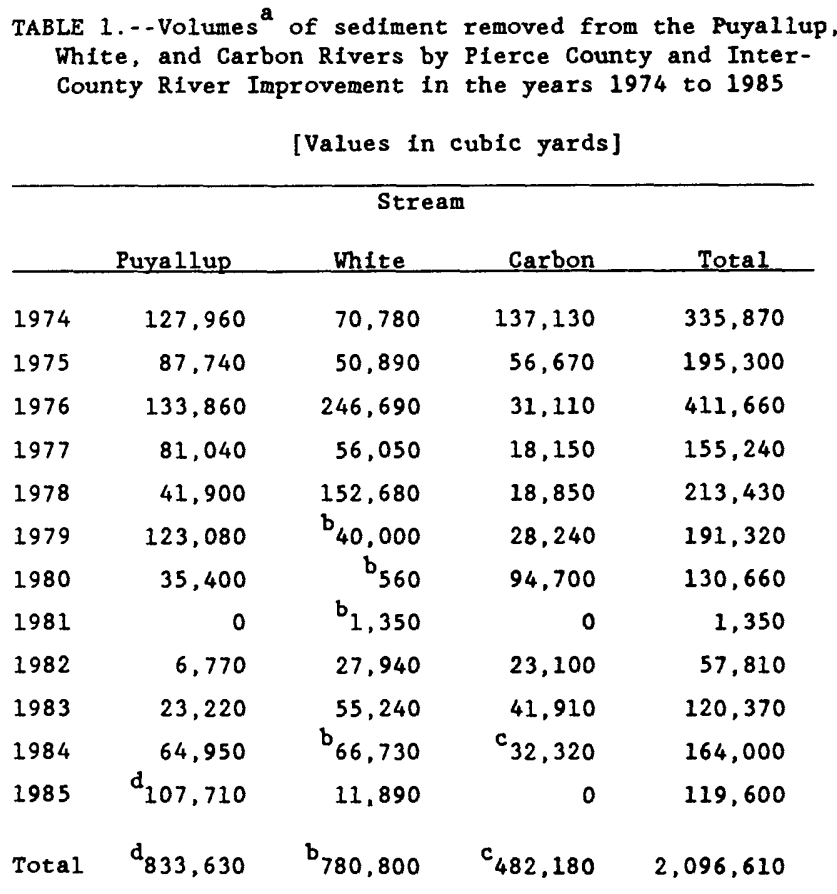

\footnotetext{
a Volumes computed from data supplied by $\mathrm{Mr}$. David $\mathrm{E}$. Lewis, Pierce County and Inter-County River Improvement, 1986.

${ }^{b}$ Some of this material removed from the Greenwater River,

a tributary to the White River upstream of Mud Mountain Dam.

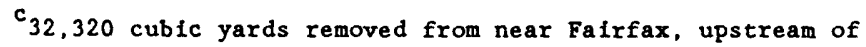
study area.

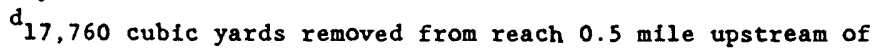
study axea.
} 
The present Puyallup River channel and levees in the reach extending 3 miles upstream from the river's mouth were constructed in 1947 through 1950 by the U.S. Army Corps of Engineers. During 1963 approximately 600,000 cubic yards were dredged from the downstream-most $1 \mathrm{mile}$ of this reach for use as construction material (R. P. Sellevold, Chief Engineering Division, U.S. Army Corps of Engineers, Seattle, Wash., written commun., 1982). The Corps of Engineers has also periodically removed vegetation from the streamward sides of the levees.

Private parties also remove material from the river, usually for use in construction. Locations of removal areas used by private parties since 1981 are available in the records of hydraulic permits issued by the state of Washington Department of Fisheries. These permits are required for any work done in the river channel, including that done by PCRI and ICRI. The permits usually allow work to be done only above the water line and only during the season when the work would be least disruptive to salmon and steelhead trout. This is usually late July through early October.

The files of hydraulic permits identify two sites of private gravel removal on the White River, one in the 1-mile-long reach downstream from the R Street bridge at Auburn (between cross sections W6.33 and W7.51 on panel I of figure A2), and the other is within one-half mile and downstream of the $8 \mathrm{th}$ Street bridge. A number of sites are on the Puyallup River in the reach between a point about 1 mile upstream of Alderton and a point about 1 mile downstream from Orting (between cross sections $P 96$ and P120 on panels $E$ and F of fig. A2). There are no sites identified on the Carbon River. Unfortunately no data are available on the volume of material removed.

In addition to the removal of sediment from streams for channel maintenance and for construction material, sediment is also removed from the white River with the water diverted to Lake Tapps. Presently (1986) most of the diverted gravel and larger sizes of sediment are returned to the river a short distance downstream from the diversion. However, most of the sand and smaller material, which constitutes about 95 percent of the directed sediment, is retained. Cooper (1983) estimated that approximately 500,000 tons (about 400,000 cubic yards) of sediment were diverted from the white River during a 1year period starting in November 1971 (Robert Barnes, Puget Sound Power and Light Co., oral commun., 1986). 


\section{General Hydrology}

The mean annual discharge from the Puyallup River basin at the streamgaging station on the Puyallup River at Puyallup was $3,460 \mathrm{ft}^{3} / \mathrm{s}$ for water years 1943 through 1982 (years ending September 30). This is equivalent to 49.5 inches of water over the drainage area of 948 square miles upstream from the gage. The White River contributes about 50 percent of this flow and the Carbon River about 30 percent.

Mean annual precipitation in the basin tends to increase with land-surface altitude. Observed long-term mean-annual precipitation ranges from 37 inches at Tacoma at an altitude of 267 feet near the mouth of the Puyallup River to 59 inches at Greenwater in the White River drainage at an altitude of 1,730 feet (U.S. National Oceanic and Atmospheric Administration, 1978), and probably exceeds 100 inches at some locations in the basin near the crest of the Cascades.

About 65 percent of the precipitation falls during the 5 months October through February. The predominant form of precipitation in the basin varies from rain at the lower altitudes to snow at the upper altitudes. Because most of the basin area lies upstream of the study reaches, and because precipitation amounts are greater in the higher upstream parts of the basin, flooding in the study area is mostly the result of rainfall and snowmelt runoff from the upstream areas. Major flooding is usually the result of runoff from frontal storms of large areal extent that move over the area in a northeasterly direction from the Pacific Ocean. The severity of flooding increases when rainfall runoff is accompanied by runoff from melting snow. Annual peak stream discharges usually occur in late fall or winter.

\section{Flow Regulation}

Flows in parts of the lower Puyallup River basin are regulated by a floodstorage reservoir behind Mud Mountain Dam and by a hydroelectric development at Lake Tapps. Both are in the White River drainage (see fig. 1). A hydroelectric development near Electron on the Puyallup River has very little storage capacity and has almost no effect on floodflows in the study area.

Mud Mountain Dam is operated by the U.S. Army Corps of Engineers. It was put in operation in 1943 and provides flood protection for land along the White River downstream of the dam and along the Puyallup River downstream of the White River. Water is usually stored behind Mud Mountain Dam when the Puyallup River is at flood levels. This water is released soon after the flood in the Puyallup River subsides.

The hydroelectric developments at Lake Tapps and Electron are operated by Puget Sound Power and Light Company. At the Lake Tapps development water is diverted from the White River near the city of Buckley into Lake Tapps. Water is withdrawn from the lake to produce power and returned to the White River at Dieringer. Discharge in the White River between the diversion and the return point is reduced by the amount diverted. Discharge in the reaches downstream of the return can also be reduced by ceasing power generation but continuing diversion into lake Tapps. The capacities of the diversion canal and the outlet from the powerplant are each about $2,000 \mathrm{ft}^{3} / \mathrm{s}$. 


\section{Flood Discharges}

A 71-year record of annual peak discharges in the Puyallup River at Puyallup is shown graphically in figure 3 . The largest flood in this record $(57,000 \mathrm{ft} / \mathrm{s})$ occurred in December 1933 before the construction $\beta^{\mathrm{f}}$ Mud Mountain Dam. Two floods with peak discharges greater than $40,000 \mathrm{ft} / \mathrm{s}$ have occurred since completion of the dam. 3 One in January $1965(41,500 \mathrm{ft} / \mathrm{s})$ and the other in December $1977\left(40,600 \mathrm{ft}^{3} / \mathrm{s}\right)$.

Estimates of peak flood discharges with average recurrence intervals of 10 , 50 , and 100 years for the different river reaches in the study area are given in table 2. This set of discharges was selected by the Survey from two sets of independently obtained estimates; one by the U.S. Army Corps of Engineers (Richard W. McLaughlin, Chief, Hydrology and Hydraulics Branch, Seattle District, written commun., 1985), and the other by the U.S. Geological Survey. Most of the estimates by the Survey were obtained by fitting log-Pearson type III distributions to observed annual peak discharges at gaging stations (U.S. Water Resources Council, 1981). Discharges estimated by the Corps of Engineers were obtained using the same or a similar method, but also with (1) expected probability adjustments (see, for example, U.S. Water Resources Council, 1981, Appendix II), (2) correlations with data from nearby gaging stations when making estimates for a station, and (3) consideration of the operating rules for Mud Mountain Dam when appropriate. Footnotes in table 2 give the source of the discharge used for each reach and compare the two estimates. 


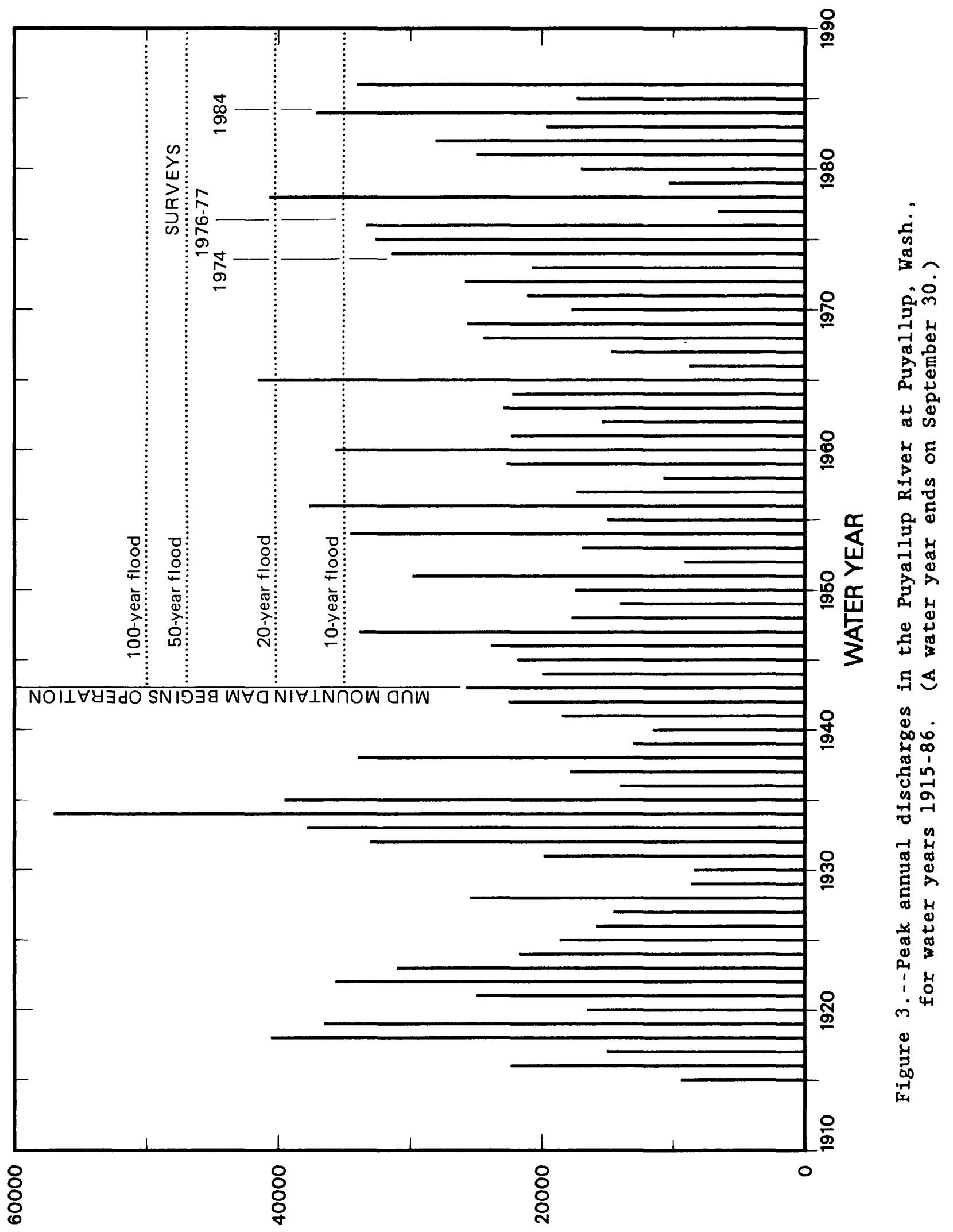

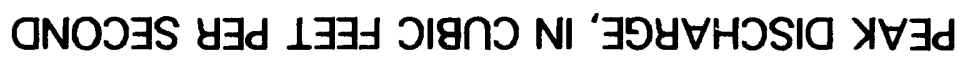


TABLE 2.--Estimated flood-peak discharges for reaches of the lower Puyallup, White and Carbon Rivers, and estimated colncident discharges in tributarles for use in computing water-surface profiles

River and reach

Flood-peak discharges, for indicated average recurrence intervals, and coincident discharges in tributarles, in cublc feet per second

10-year 50-year 100-year

$\frac{\text { Puyallup RIver }}{\text { Mouth to White RIver }{ }^{1}}$

White River to Carbon Rivęr ${ }^{2}$

Colncident in White River

Carbon River to gage near grting 4

$\begin{array}{lll}35,000 & 47,000 & 50,000 \\ 23,000 & 32,000 & 36,000 \\ 12,000 & 15,000 & 14,000 \\ 11,000 & 15,000 & 17,000 \\ 12,000 & 17,000 & 19,000\end{array}$

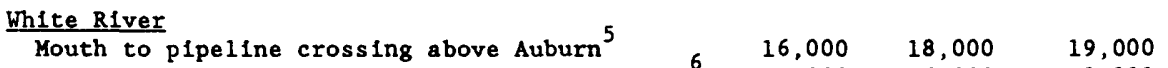

Colncident In Puyallup River above confluence $\begin{array}{rrrr}6 & 9,000 & 16,000 & 18,000\end{array}$

Carbon River

Mouth to South Prairie Creek ${ }^{7}$

Colncident in Puyallup River above confluegnce 3

South Prairle Creek to Highway 163 bridge

Colncident in South Prairle Creek

$\begin{array}{rrr}14,000 & 20,000 & 23,000 \\ 9,000 & 12,000 & 13,000 \\ 9,000 & 13,000 & 15,000 \\ 5,000 & 7,000 & 8,000\end{array}$

${ }^{1}$ Discharges estimated by the U.S. Army Corps of Engineers taking into consideration operating rules for Mud Mountain Dam. Discharges are within 10 percent and are well within the 95 -percent confidence band of those the U.S. Geological Survey estimated by fitting a log-Pierson Type III distribution (U.S. Water Resources Counc1l, 1981) to annual peak discharges for the gaging station at Puyallup (12101500). Water-surface elevations of mouth assumed equal to mean higher high water in Commencement Bay, 5.4 feet above sea level.

2 Discharges estimated by the U.S. Army Corps of Engineers for the Puyallup River at Alderton. Discharges are up to 30 percent higher and 11 e within but near the upper $11 \mathrm{mit}$ of the 95 -percent confidence band of those the U.S. Geological Survey estimated by fitting a log-Pearson Type III distribution (U.S. Water Resources Counc11, 1981) to annual peak discharges for the gaging station at Alderton (12096500).

${ }^{3}$ Discharges obtained by taking differences between flood-peak discharges in combined streams below confluence and other stream above confluence.

${ }^{4}$ DIscharges the U.S. Geological survey estimated by fitting a log-Plerson Type III distribution (U.S. Water Resources Council, 1981) to annual peak discharges at the gaging station near orting (12093500). These discharges are within 5 percent of those estimated by the U.S. Army Corps of Engineers for the gage site.

${ }^{5}$ Discharges estimated by the U.S. Army Corps of Engineers taking Into consideration operating rules for Mud Mountain Dam. Discharges are within 20 percent and are well within the 95-percent confidence band of those the U.S. Geological Survey estimated by fitting a log-Pierson Type III distribution (U.S. Water Resources Counc1l, 1981) to annual peak discharges at the gaging station near Sumner (12100500).

${ }^{6}$ Discharges estimated by the U.S. Army Corps of Engineers taking into consideration operating rules for Mud Mountain Dam.

7 No data avallable for directly obtaining discharges for this reach. Discharges obtained by the U.S. Geological Survey by comparing flood-peak discharges for the different recurrence intervals in the Puyallup River above and below the Carbon River and in the Carbon River at the Fairfax gages (12093900 and 12094000) and In South Prairle Creek at South Prairle (12095000). The estimated discharges are within 10 percent of those estimated by the U.S. Army Corps of Engineers by similar methods.

${ }^{8}$ Discharges estimated by the U.S. Army Corps of Engineers. Discharges are within 10 percent of those the U.S. Geological survey estimated by fitting a log-Plerson Type III distribution (U.S. Water Resources Counc11, 1981) to annual peak discharges at the Fafrfax gages (12093900 and 12094000) and multiplying by ratio of dralnage area above South Prairle Creek to the area above the gages. 


\section{FLOOD-CARRYING CAPACITIES OF 1984 CHANNELS}

Flood-carrying capacities of the 1984 channels (tables 3 through 5) were estimated at each of the surveyed cross sections by comparing computed watersurface elevations for a range of discharges with the elevations of the banks or levees. The profiles were computed using cross-section-geometry data from the 1984 survey and hydraulic roughness coefficients obtained by calibration with data from 1974 to 1977 (see "Methods" subsection in the Introduction). When making these computations, water was constrained to flow within the channel banks by artificially raising the top-of-bank or levee elevations to whatever height necessary. The profiles of computed water-surface elevations and of bank or levee-top elevations are shown graphically in figures A3 through $A 5$ and the numerical values are given in tables Al through A3 of the appendix.

Up to four different capacities were estimated for each cross section. Each capacity was obtained using a different bank or levee elevation. These elevations were (1) top of left bank or levee, (2) top of right bank or levee, (3) 3 feet below top of left levee, and (4) 3 feet below top of right levee. The left-right convention is for an observer facing downstream. The 3-foot freeboard provides a margin of safety against failure of constructed levees. Its use is required in some cases by the Federal Emergency Management Agency (1985) when determining risks for setting flood-insurance premiums when the land elevation shoreward of the levee is lower than the elevation of the top of the levee.

All longitudinal water-surface profiles were computed by numerically solving the open-channel-flow backwater equation with the U.S. Geological Survey computer program J635. The program is nearly identical to program E431 described by Shearman (1976). Equations assume one-dimensional flow; therefore, variations in water-surface elevation across a channel such as occurs at river bends, are not computed.

The data required for computing water-surface profiles are water discharges, the shapes and elevations (geometry) of the river cross sections, distances along the river between cross sections, and values of the channel roughness coefficient in the Manning flow equation (see Shearman, 1976).

Water discharges for floods with various average recurrence intervals were estimated by both the U.S. Army Corps of Engineers and the U.S. Geological Survey and are presented in table 2. The shape and elevation of the stream cross sections were obtained from the field surveys, and distances between cross sections were from maps that were prepared by photogrammetry. Because the computed water-surface elevations for different conditions were to be compared, a11 computations were made using the same number and locations of cross sections. Although a greater number of cross sections were surveyed in 1977 and 1974 than in 1984, only those resurveyed in 1984 were used in the computations.

Hydraulic roughness coefficients for the 1977 channels of the Puyallup and Carbon Rivers and the reach of the White River in Pierce County were obtained by a calibration procedure in which the coefficients were adjusted so that computed water-surface elevations for a flood that occurred in December 1977 closely approximated the elevations of observed high-water marks for that flood. The recurrence intervals for peak discharges during this flood varied 
with the stream reach and ranged from 5 to 30 years. Coefficients for the reach of the White River in King County were obtained by a similar procedure using high-water elevations, furnished by the U.S. Army Corps of Engineers (George Ristau, written commun., 1984), observed during a controlled release of 3 water from Mud Mountain Dam. The discharge during this release was 10,300 $\mathrm{ft} / \mathrm{s}$, which has a recurrence interval of less than 2 years. In all computations for calibration, water was not constrained to flow within the channel banks as was done when computing water-surface profiles for obtaining floodcarrying capacities.

The roughness coefficients obtained by calibration with data from 1974 or 1977 were also used in computations of water-surface profiles for the 1984 channels. The original project plans included obtaining roughness coefficients for 1984 channels by calibration using high-water elevations that were to be observed during a flood in the winter of 1984-85; however, no flood occurred that winter. Roughness coefficients might have changed between 1974-77 and 1984 because of changes in the amount of streambank vegetation, changes in the bed forms or sediment sizes on the channel bottoms, or new structures in the river channel. The possible effects of streambank vegetation on water-surface elevations are discussed in a later section. There is no reason to suspect appreciable changes in bed forms on sediment sites, and there had been no new structures constructed in the channel except for the replacement of the bridge across the Puyallup River between cross sections P87 and P90 (see panel E of fig. A2).

\section{Puyallup River}

The flood-carrying capacity of the Puyallup River channel between it mouth and the city of Puyallup (cross-section P50) equals or exceeds $50,000 \mathrm{ft} / \mathrm{s}$, the estimated peak discharge of the 100-year flood, at most cross sections (table 3). See various panels of figure A2 in appendix A for location of cross sections. At all but one of the cross sections where the capacity is less, the computed water-surface elevations for the 100 -year flood are 1.8 feet or more below the top of the levee (table Al). The exception is at cross-section $\mathrm{P} 48$ where the flood-carrying capacity is limited by a low unleveed left bank.

In the reach between cross-section $P 50$ and cross-section P110 (about 3,000 feet upstream of the confluence with the Carbon River) the 100-year flood elevation is higher than the tops of levees and unleveed banks at many cross sections.

In the reach between cross-section P110 and cross-section P150.2 (about 5 miles upstream from the town of Orting) the river is leveed along most banks. Upstream of cross-section P141, where the valley floor is only about one-half mile wide, flood-carrying capacity with 3 feet of freeboard equals or exceeds the 100-year flood discharge, $17,200 \mathrm{ft}^{3} / \mathrm{s}$. Downstream of cross-section P141, where the valley floor is nearly 2 miles wide, the town of orting is located, and across which the Carbon River also flows, the flood-carrying capacity is less than the 100-year flood at most locations. The water-surface elevation for the 100-year flood is higher than the top of levee on the right bank near and downstream of Orting. Reconstruction of the levee at cross-section P141 since the time of the 1984 survey may have corrected the need for additional freeboard at that site. 
The flood-carrying capacity of the White River channel at most of the cross sections in Plerce County, where there are no levees, is less than $19,000 \mathrm{ft}^{3} / \mathrm{s}$, the 100-year-flood discharge (table 4). Computed water-surface elevations for the 100-year flood at many of the cross sections in this reach are higher than the tops of the banks on either side of the river (table A2).

In King County there are levees along most of the entire left bank and along most of the right bank downstream from the $R$ Street bridge in Auburn. Upstream from the bridge there is a high natural bank on the right side. The levees on the White River in King County would be adequate to contain the 100year flood with 3 feet of freeboard at most locations if the dike were in a good state of repair. However, washed-out sections of the dike on the left bank near cross-sections 8.60 and 9.51 (upstream from Auburn) permit water to flow through the levee almost every year (see fig. A4).

\section{Carbon River}

The levee on the left bank lacks 3 feet of freeboard for the 100-year flood at the six cross sections, $C 1$ through $\mathrm{Cl}$, near the mouth (see fig. A2, panels $F$ and $K$ for cross-section locations), at about one-third of the cross sections in the central part of the study area, at two of the three cross sections upstream of South Prairie Creek (table 5), and at many locations between the surveyed cross sections. At three of the cross sections near the mouth, $C 1$, C4, and $\mathrm{C} 6$ and at one upstream of South Prairie Creek, C32, the computed water level is higher than the top of the levee. The levee on the right bank lacks 3 feet of freeboard at three cross sections near the mouth and at two upstream of South Prairie Creek. At two of the cross sections near the mouth, C4 and C6, the computed water-surface elevations for the 100-year flood is above the top of the levee. At most other locations on the right bank of the Carbon River there is a high natural bank.

\section{Discussion}

Numerous assumptions were made in obtaining the water-surface profiles and flood-carrying capacities that are given in the preceding subsection. An understanding of some of these assumptions is necessary for an intelligent use of the listed capacities. One of the assumptions is that the constructed levees would be structurally stable during a 100-year flood. An analyses of a levees' resistance to fallure by erosion, stream undercutting, or piping are not within the scope of this investigation. The only criteria employed was that of the 3 feet of freeboard.

Another assumption was that flow in the stream channel would not be restricted by debris during a flood. However, it should be recognized that floating debris, such as trees, can and often do get caught and accumulate on bridge piers or other obstructions in river channels. The resulting flow restrictions cause increased water levels upstream of the obstructions. Insufficient data exist on the frequency of occurrence, location, or the magnitude of such flow restrictions; consequently, they were not considered in the computation of water-surface elevations. 
Still another assumption was that at the time of the flood-peak discharge the tide elevation in Commencement Bay was equal to mean higher high water (long-term average of the higher of the two daily high tides). Higher tide stages would result in higher water-surface elevations in the Puyallup River near its mouth. Water-surface profiles that were computed using a tide stage 5 feet higher than mean higher high water were 5 feet higher at the rivers mouth, but were only 1 foot higher near the Tacoma city limits (cross-section P22).

One should also be careful in using the flood-carrying capacities to determine the likelihood of flooding at a cross section. A flood-carrying capacity greater than the 100-year flood at a cross section does not necessarily mean that flooding will not occur at that cross section during a 100-year flood. It is possible that lands at that cross section could be inundated with water that escapes the channel at locations either upstream or downstream where the floodcarrying capacity is less. 
TABLE 3. - Flood-carrying capacities of the lower Puyallup River channel at cross sections surveyed in $\mathbf{1 9 8 4}$

\begin{tabular}{|c|c|c|c|c|c|}
\hline \multirow{3}{*}{$\begin{array}{l}\text { Cross- } \\
\text { section } \\
\text { index } \\
\text { number }\end{array}$} & \multirow{3}{*}{$\begin{array}{l}\text { Distance } \\
\text { from } \\
\text { mouth, } \\
\text { in feet }\end{array}$} & \multicolumn{4}{|c|}{$\begin{array}{l}\text { Discharge, in cubic feet per second, at indicated } \\
\text { water levels. Left and right are in reference to } \\
\text { an observer facing downstream. }\end{array}$} \\
\hline & & \multicolumn{2}{|c|}{ Left } & \multicolumn{2}{|c|}{ Right } \\
\hline & & $\begin{array}{l}\text { Top bank } \\
\text { or levee }\end{array}$ & $\begin{array}{l}3 \text { ft below } \\
\text { top levee }\end{array}$ & $\begin{array}{l}\text { Top bank } \\
\text { or levee }\end{array}$ & $\begin{array}{l}3 \text { ft below } \\
\text { top levee }\end{array}$ \\
\hline $\mathrm{P} 2 \mathrm{a}$ & 1610 & $>50000$ & (b) & $>50000$ & (b) \\
\hline $\mathrm{P} 4 \mathrm{a}$ & 3580 & $>50000$ & (b) & $>50000$ & (b) \\
\hline P8a & 5780 & $>50000$ & (b) & $>50000$ & $>50000$ \\
\hline $\mathrm{P} 10 \mathrm{a}$ & 7670 & $>50000$ & $>50000$ & $>50000$ & $>50000$ \\
\hline P13a & 9700 & $>50000$ & $>50000$ & $>50000$ & $>50000$ \\
\hline $\mathrm{P} 16 \mathrm{a}$ & 11540 & $>50000$ & $>50000$ & $>50000$ & $>50000$ \\
\hline $\mathrm{P} 18 \mathrm{a}$ & 12960 & $>50000$ & $>50000$ & $>50000$ & $>50000$ \\
\hline $\mathrm{P} 20 \mathrm{a}$ & 14740 & $>50000$ & (b) & $>50000$ & $>50000$ \\
\hline $\mathrm{P} 22 \mathrm{a}$ & 16040 & $>50000$ & 50000 & $>50000$ & $>50000$ \\
\hline $\mathrm{P} 24 \mathrm{a}$ & 17960 & $>50000$ & 47500 & $>50000$ & $>50000$ \\
\hline P26 & 19880 & $>50000$ & 47000 & $>50000$ & $>50000$ \\
\hline P28 & 21700 & $>50000$ & 46600 & $>50000$ & $>50000$ \\
\hline P30 & 23650 & $>50000$ & 46100 & $>50000$ & $>50000$ \\
\hline P32 & 25490 & $>50000$ & $>50000$ & $>50000$ & $>50000$ \\
\hline P34 & 27480 & $>50000$ & $>50000$ & $>50000$ & $>50000$ \\
\hline P36 & 29340 & $>50000$ & $>50000$ & $>50000$ & $>50000$ \\
\hline P38 & 30630 & $>50000$ & $>50000$ & $>50000$ & $>50000$ \\
\hline $\mathrm{P} 40$ & 32710 & $>50000$ & 47500 & $>50000$ & $>50000$ \\
\hline \multicolumn{6}{|c|}{ (ng a } \\
\hline $\mathrm{P} 42$ & 34640 & $>50000$ & 47400 & $>50000$ & $>50000$ \\
\hline $\mathrm{P} 44$ & 36340 & $>50000$ & 47000 & $>50000$ & $>50000$ \\
\hline $\mathrm{P} 46$ & 38100 & $>50000$ & $>50000$ & $>50000$ & $>50000$ \\
\hline $\mathrm{P} 48$ & 40090 & 30400 & (b) & $>50000$ & $>50000$ \\
\hline P50 & 42020 & $>50000$ & (b) & $>50000$ & 44800 \\
\hline P53 & 44320 & 39500 & (b) & 42000 & (b) \\
\hline P56 & 46640 & $>50000$ & (b) & 22300 & (b) \\
\hline P58 & 48050 & $>50000$ & (b) & 42000 & (b) \\
\hline $\mathrm{P} 61$ & 50570 & 33200 & (b) & $>50000$ & (b) \\
\hline $\mathrm{P} 62$ & 51530 & 37000 & (b) & $>50000$ & (b) \\
\hline $\mathrm{P} 64$ & 53510 & $>50000$ & (b) & 49200 & (b) \\
\hline \multicolumn{6}{|c|}{ - White River enters } \\
\hline P65 & 54410 & 21400 & (b) & 18900 & (b) \\
\hline P66 & 55550 & $>36000$ & (b) & 22300 & (b) \\
\hline P70 & 58170 & 28100 & (b) & 31200 & 22000 \\
\hline P72 & 60460 & 19900 & (b) & 25700 & (b) \\
\hline P74 & 62540 & $>36000$ & (b) & $>36000$ & (b) \\
\hline \multicolumn{6}{|c|}{ - Gage at Alderton } \\
\hline P77 & 64640 & $>36000$ & (b) & $>36000$ & (b) \\
\hline P79 & 66500 & 33000 & (b) & 23900 & (b) \\
\hline P81 & 68440 & 21200 & (b) & 19700 & (b) \\
\hline P83 & 70520 & 26000 & 18500 & 15500 & (b) \\
\hline P85 & 72500 & 19100 & $<13200$ & $>36000$ & (b) \\
\hline
\end{tabular}


TABLE 3. --Flood-carrying capacities of the lower Puyallup River channel at cross sections surveyed in 1984--Continued

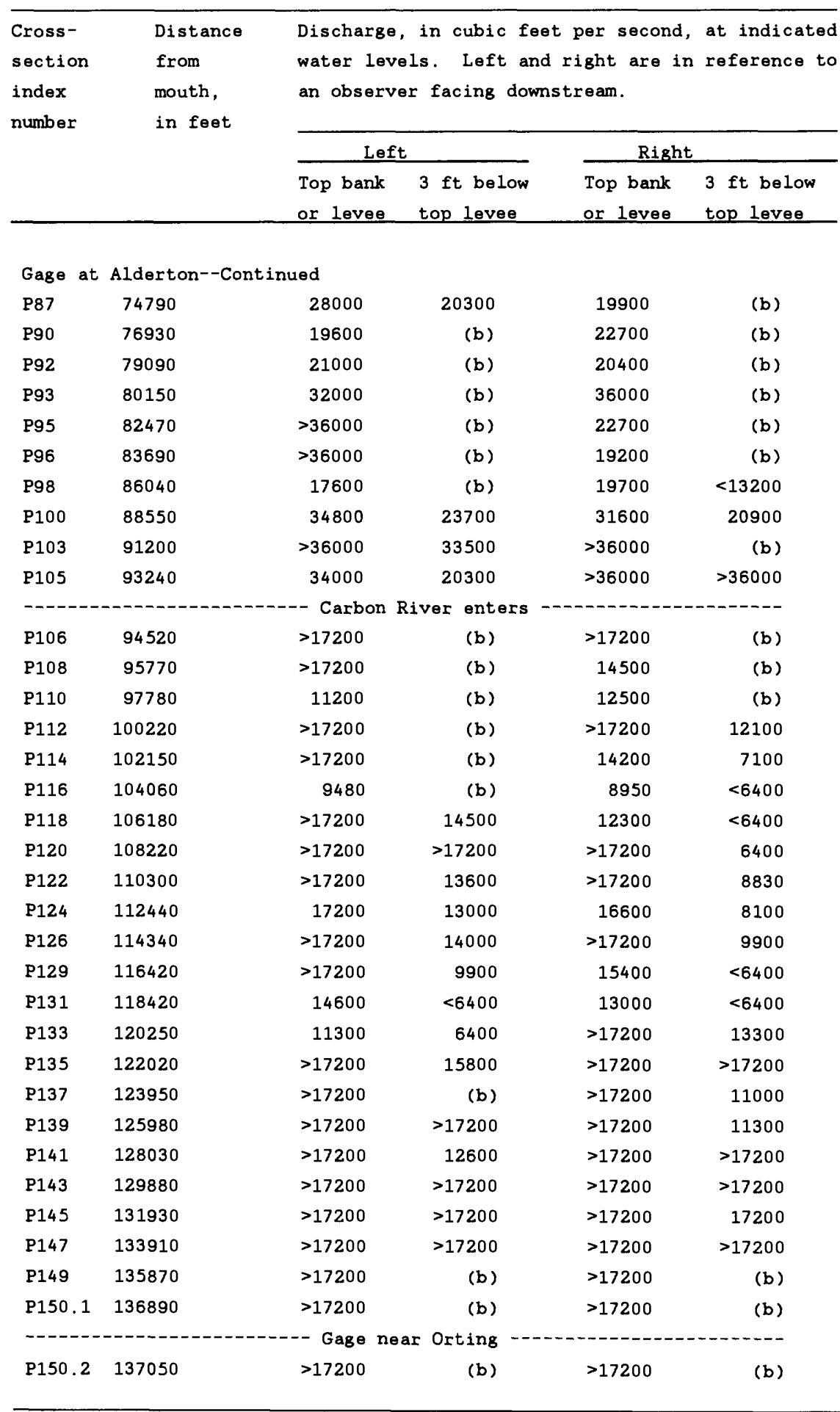

alood-carrying capacity at this cross section is less than indicated when tide stage in Commencement Bay is higher than mean higher high water.

bank without levee not requiring 3 feet of freeboard. 
TABLE 4. --Flood-carrying capacities of the lower White River channel at cross sections surveyed in 1984

\begin{tabular}{|c|c|c|c|c|c|}
\hline \multirow[t]{3}{*}{$\begin{array}{l}\text { Cross- } \\
\text { section } \\
\text { index } \\
\text { number }\end{array}$} & \multirow[t]{3}{*}{$\begin{array}{l}\text { Distance } \\
\text { from } \\
\text { mouth, } \\
\text { in feet }\end{array}$} & \multirow{2}{*}{\multicolumn{4}{|c|}{$\begin{array}{l}\text { Discharge, in cubic feet per second, at indicated } \\
\text { water levels. Left and right are in reference to } \\
\text { an observer facing downstream. } \\
\text { Left } \\
\end{array}$}} \\
\hline & & & & & \\
\hline & & $\begin{array}{l}\text { Top bank } \\
\text { or levee }\end{array}$ & $\begin{array}{l}3 \mathrm{ft} \text { below } \\
\text { top levee }\end{array}$ & $\begin{array}{l}\text { Top bank } \\
\text { or levee }\end{array}$ & $\begin{array}{l}3 \text { ft below } \\
\text { top levee }\end{array}$ \\
\hline W39c & 450 & $30000 \mathrm{c}$ & (b) & $22800 c$ & (b) \\
\hline W41c & 1910 & $47400 \mathrm{c}$ & (b) & $40900 c$ & (b) \\
\hline W44c & 4130 & $48000 c$ & (b) & $>50000 c$ & (b) \\
\hline W46c & 5970 & $>50000 c$ & (b) & $>50000 \mathrm{c}$ & (b) \\
\hline W49c & 7670 & $>50000 c$ & (b) & $41400 c$ & (b) \\
\hline W51c & 9620 & $31600 c$ & (b) & $42400 c$ & (b) \\
\hline W53 & 11530 & 17800 & (b) & 18700 & (b) \\
\hline W55 & 13680 & $>19000$ & (b) & 12000 & (b) \\
\hline W57 & 15750 & 17000 & (b) & 11900 & (b) \\
\hline W59 & 17960 & 12200 & (b) & 15700 & (b) \\
\hline \multicolumn{6}{|c|}{ Inflow from Lake Tapps at Dieringer } \\
\hline W61 & 20370 & 13700 & (b) & 13600 & (b) \\
\hline W62 & 21340 & 16700 & (b) & 12600 & (b) \\
\hline W64 & 23670 & 11700 & (b) & $>19000$ & (b) \\
\hline \multicolumn{6}{|c|}{ - } \\
\hline W66 & 25970 & 19000 & (b) & $>19000$ & (b) \\
\hline W68 & 27480 & 13400 & (b) & 10800 & (b) \\
\hline \multicolumn{6}{|c|}{ - Pierce/King County line - } \\
\hline W70 & 29620 & $>19000$ & 15100 & $>19000$ & (b) \\
\hline W5. 97 & 31520 & $>19000$ & $>19000$ & $>19000$ & $>19000$ \\
\hline W6. 33 & 33420 & $>19000$ & $>19000$ & $>19000$ & $>19000$ \\
\hline W6. 73 & 35530 & $>19000$ & $>19000$ & $>19000$ & $>19000$ \\
\hline W7. 09 & 37440 & $>19000$ & (b) & $>19000$ & $>19000$ \\
\hline W7. 40 & 39070 & $>19000$ & 16000 & $>19000$ & (b) \\
\hline W7. 51 & 39650 & $>19000$ & (b) & $>19000$ & (b) \\
\hline \multicolumn{6}{|c|}{ - R Street bridge at Auburn } \\
\hline W7. 74 & 40870 & $>19000$ & $>19000$ & $>19000$ & (b) \\
\hline W8. 03 & 42400 & $>19000$ & $>19000$ & $>19000$ & (b) \\
\hline W8. 19 & 43240 & $>19000$ & $>19000$ & $>19000$ & (b) \\
\hline พ8. 33 & 43980 & $>19000$ & $>19000$ & $>19000$ & (b) \\
\hline W8. 46 & 44670 & $>19000$ & $>19000$ & $>19000$ & (b) \\
\hline W8. 60 & 45410 & $>19000$ & $>19000$ & $>19000$ & (b) \\
\hline พ8. 73 & 46090 & $>19000$ & $>19000$ & $>19000$ & (b) \\
\hline W8. 89 & 46940 & $>19000$ & $>19000$ & $>19000$ & (b) \\
\hline W9. 02 & 47630 & $>19000$ & $>19000$ & $>19000$ & (b) \\
\hline W9. 18 & 48470 & $>19000$ & $>19000$ & $>19000$ & (b) \\
\hline w9. 33 & 49260 & $>19000$ & $>19000$ & $>19000$ & (b) \\
\hline W9. 51 & 50210 & $>19000$ & $>19000$ & $>19000$ & (b) \\
\hline พ9. 81 & 51800 & $>19000$ & $>19000$ & $>19000$ & (b) \\
\hline W10.04 & 53010 & $>19000$ & $>19000$ & $>19000$ & (b) \\
\hline W10. 25 & 54120 & $>19000$ & $>19000$ & $>19000$ & (b) \\
\hline W10. 42 & 55020 & $>19000$ & $>19000$ & $>19000$ & (b) \\
\hline W10.58 & 55860 & $>19000$ & 18500 & $>19000$ & (b) \\
\hline
\end{tabular}


TABLE 5. --Flood-carrying capacities of the lower Carbon River channel at cross sections surveyed in 1984

\begin{tabular}{|c|c|c|c|c|c|}
\hline \multirow{3}{*}{$\begin{array}{l}\text { Cross- } \\
\text { section } \\
\text { index } \\
\text { number }\end{array}$} & \multirow{3}{*}{$\begin{array}{l}\text { Distance } \\
\text { from } \\
\text { mouth, } \\
\text { in feet }\end{array}$} & \multicolumn{4}{|c|}{$\begin{array}{l}\text { Discharge, in cubic feet per second, at indicated } \\
\text { water levels. Left and right are in reference to } \\
\text { an observer facing downstream. }\end{array}$} \\
\hline & & \multicolumn{2}{|c|}{ Left } & \multicolumn{2}{|c|}{ Right } \\
\hline & & $\begin{array}{l}\text { Top bank } \\
\text { or levee }\end{array}$ & $\begin{array}{l}3 \text { ft below } \\
\text { top levee }\end{array}$ & $\begin{array}{l}\text { Top bank } \\
\text { or levee }\end{array}$ & $\begin{array}{l}3 \text { ft below } \\
\text { top levee }\end{array}$ \\
\hline C1 & 640 & 19400 & 10900 & $>23000$ & $>23000$ \\
\hline $\mathrm{C2}$ & 1720 & $>23000$ & 16800 & $>23000$ & 20400 \\
\hline $\mathrm{C} 4$ & 3570 & 12500 & $<7500$ & 20000 & 10900 \\
\hline C6 & 5590 & 18300 & 9440 & 20300 & 12000 \\
\hline $\mathrm{C} 8$ & 7490 & $>23000$ & 15700 & $>23000$ & (b) \\
\hline C10 & 9440 & 23000 & 14800 & $>23000$ & (b) \\
\hline C12 & 11450 & $>23000$ & $>23000$ & $>23000$ & (b) \\
\hline C14 & 13550 & $>23000$ & $>23000$ & $>23000$ & (b) \\
\hline C16 & 15840 & $>23000$ & 17800 & $>23000$ & (b) \\
\hline C17 & 16630 & $>23000$ & $>23000$ & $>23000$ & (b) \\
\hline C18 & 17730 & $>23000$ & $>23000$ & $>23000$ & (b) \\
\hline C19 & 18580 & $>23000$ & 8500 & $>23000$ & (b) \\
\hline $\mathrm{C} 22$ & 21900 & $>23000$ & $>23000$ & $>23000$ & (b) \\
\hline $\mathrm{C} 24$ & 24310 & $>23000$ & 10000 & $>23000$ & (b) \\
\hline $\mathrm{C} 26$ & 26250 & $>23000$ & $>23000$ & $>23000$ & (b) \\
\hline $\mathrm{C} 28$ & 28160 & $>23000$ & $>23000$ & $>23000$ & (b) \\
\hline Сзо & 30030 & $>23000$ & 20000 & $>23000$ & (b) \\
\hline \multicolumn{6}{|c|}{ - Prairie Creek enters -- } \\
\hline C31 & 30600 & $>15000$ & 10200 & $>15000$ & 8780 \\
\hline C32 & 31260 & 14300 & 7650 & $>15000$ & 8550 \\
\hline $\mathrm{C} 33$ & 31450 & $>15000$ & $>15000$ & $>15000$ & $>15000$ \\
\hline
\end{tabular}


Changes Between $1974-77$ and 1984

Changes in channel cross-section elevations between the times of the surveys in 1974 or $1976-77$ and in 1984 were obtained by taking differences between average channel elevations at each of the cross sections. Average channel elevations were computed by two different methods in order to check if the differences were strongly dependent on the method of computation. Because both methods yielded similar results only the results using one of the methods are given in this report (fig. 4).

In each method of computation the average cross-section elevation was obtained by dividing a cross-sectional area of earth above an arbitrary datum by the width between the area's lateral boundaries, and adding the quotient to the elevation of the datum above sea level. The arbitrary datum was always chosen to be below the deepest point in the cross section. Areas were computed using the trapezoidal rule.

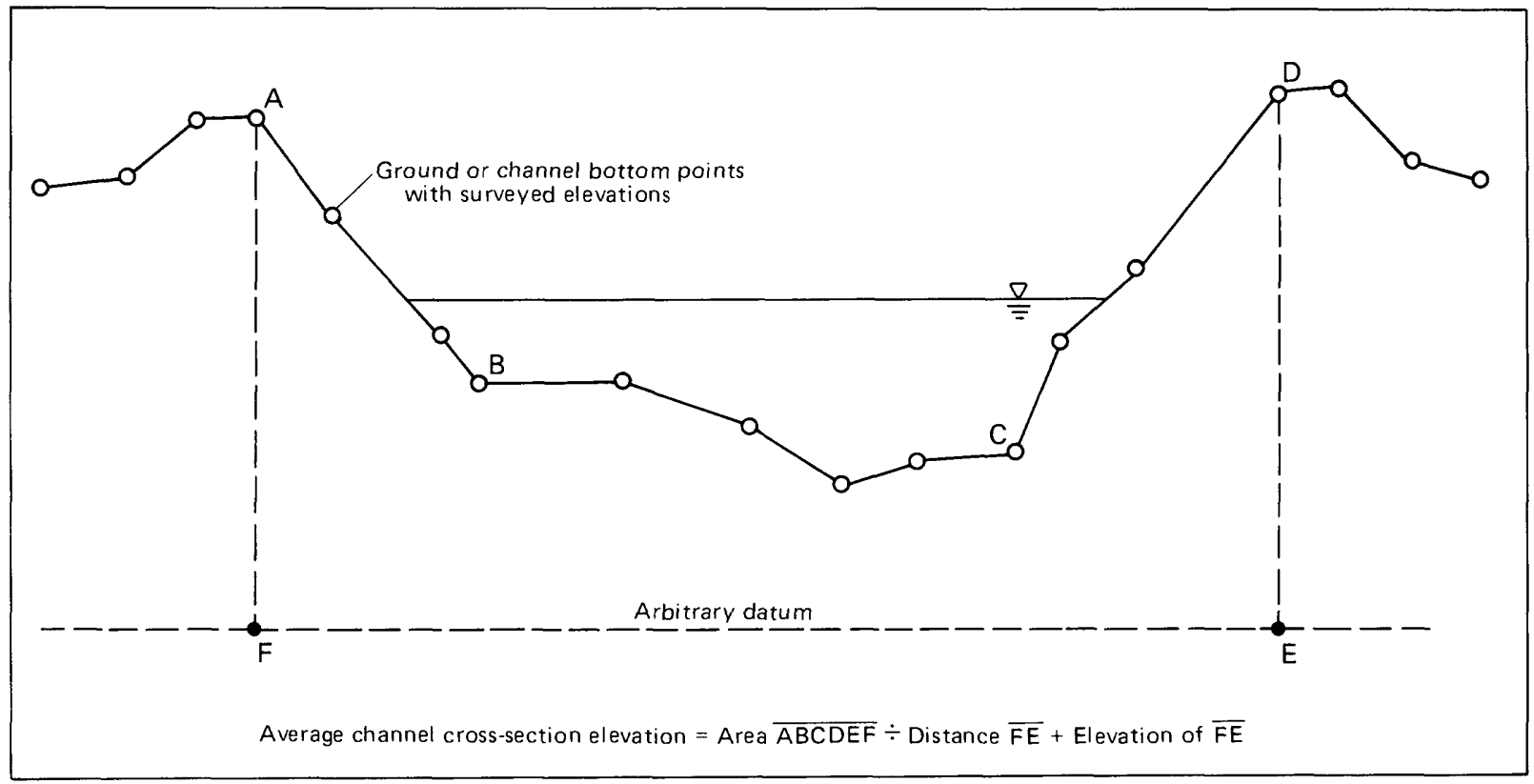

Figure 4.--Definition sketch showing method for computing average cross-section elevations at surveyed cross sections. 
The difference between the two methods is in the selection of the lateral boundaries, which in one method were at the toes of the streambanks and in the other method were at the tops of the streambanks or levees. Because the tops are more readily identified than the toes, the bank-top method was used for the results in this report. This method estimates the average elevation of the full channel cross section including the banks. When computations were made by this method identical widths (distance EF in fig. 4) were used for the old and new cross sections.

The magnitude of the probable errors in the computed changes in average elevations of cross sections between 1974 or $1976-77$ and 1984 is a function of the errors in the survey data and the errors introduced by the method of computating average elevations. The probable errors in elevations obtained in the 1984 and 1976-77 surveys are about 0.2 and 1.0 foot, respectively. The probable error in the 1974 survey of the White River in King County is unknown, but is probably in the range 0.2 to 1.0 foot. The error caused by mislocating a cross section in the 1984 survey relative to its position in the 1974 or 197677 surveys is difficult to estimate, but may be about 0.5 foot. The probable error introduced by the method used to compute the average elevation of a cross section is also difficult to estimate, but is probably about 0.2 foot. The expected error in the computed average change in elevation at a cross section is approximated by the square root of the sum of the squares of all the individual errors. Consequently, the expected error in the difference between 1984 and 1977 average elevations is:

\begin{tabular}{|c|c|c|c|c|c|}
\hline $\begin{array}{l}1984 \\
\text { data }\end{array}$ & $\begin{array}{c}1976-77 \\
\text { data }\end{array}$ & $\begin{array}{l}1984 \\
\text { method }\end{array}$ & $\begin{array}{l}1976-77 \\
\text { method }\end{array}$ & location & resultant \\
\hline
\end{tabular}

A similar computation gives 0.6 to 1.2 feet as the range in the expected error in the difference between 1984 and 1974 average elevations. Because of the uncertainty in estimates of the individual errors, it is appropriate to state that the expected error at a cross section is in the range 1 to 2 feet, except for the White River in king County where it may be 0.5 to 2 feet.

Changes from 1974 or 1976-77 to 1984 in average elevations of surveyed cross sections are plotted as functions of distances from the rivers' mouths in the upper parts of figures 5 through 7, and the differences between 100-yearflood elevations that were computed using data from the two periods are plotted in the lower parts of these figures.

When interpreting the data on changes in channel elevations in figures 5 through 7 a large emphasis should not be placed on any one or two data points. Instead, all the data in a reach containing a group of data points (perhaps three or more) should be considered collectively to determine if there is net aggradation or deepening in that reach for the period between the two surveys. The reason is that the observed change in elevation at a cross section can be sensitive to the times of the two surveys of the cross section in relation to the phases of transient geomorphic features in the river channel. The period of a transient could be as short as a fraction of an hour for small bed forms, to as long as a few years for gravel bars that move only during floods. 
Because the typical distance between cross sections (about 2,000 feet) is longer than most gravel bars, the correlation between changes in average elevations at adjacent cross sections caused by transient geomorphic features is probably small. Geomorphic features with longer lengths, such as channel meandering, probably need not be considered because the large-scale channel plan form is controlled almost everywhere by levees or stabilized banks.

\section{Puyallup River}

Changes in average elevations of cross sections in the Puyallup River (fig. 5) are not consistent in direction over any long reaches of the river. The magnitude of indicated changes at most of the cross sections is about the same as the accuracy of the method used to determine the changes. Absolute values of the changes are less than 1 foot at more than one-half of the 70 cross sections and exceed 2 feet at only three of them. There is no reach in which the calculated change is more than 1 foot in the same direction at more than two adjacent cross sections nor is there a reach where the change exceeds 2 feet at two adjacent cross sections.

Changes in computed 100-year-flood elevations for this period typically are similar in magnitude and direction to the changes in average elevations of the channel cross sections. The major difference between the changes is that in the downstream reaches of the river, where the slope is relatively mild, the variation in water-surface elevation changes between adjacent cross sections is less than the variation in average channel elevation changes. Computed changes in water-surface elevations for the 10 - and 50-year floods (not shown) are within 0.2 foot of the changes for the 100 -year flood at most cross sections.

\section{White River}

In the White River, the change in average channel elevation at most cross sections upstream of the inflow from Lake Tapps indicate that the channel was lower in 1984 than at the earlier date (fig. 6). Changes are in excess of 2 feet at more than one-third of the 29 surveyed cross sections in this reach, and exceed 4 feet at two of them. The apparent deepening of the channel could be natural or the result of private companies removing large amounts of sand and gravel for construction material from the reach between the gage near Sumner and R Street bridge at Auburn (David E. Lewis, Maintenance Supervisor, Inter-County River Improvement, Pierce County, oral commun., 1985). In the reach downstream of the inflow from Lake Tapps at Dieringer the change nearly equals or exceeds +2 feet at 5 of the 10 cross sections, suggesting a higher channe1. The reason for this apparent aggradation is unknown, but could be a consequence of the relatively mild slope in this reach.

The changes in computed 100 -year flood water-surface elevations in the White River, as in the Puyallup River, are similar in magnitude and direction to changes in average cross-section elevations. Also, longitudinal variations in changes in water-surface elevations are less than variations in changes in average cross-section elevations, especially in the low-gradient downstream reach of the river. 

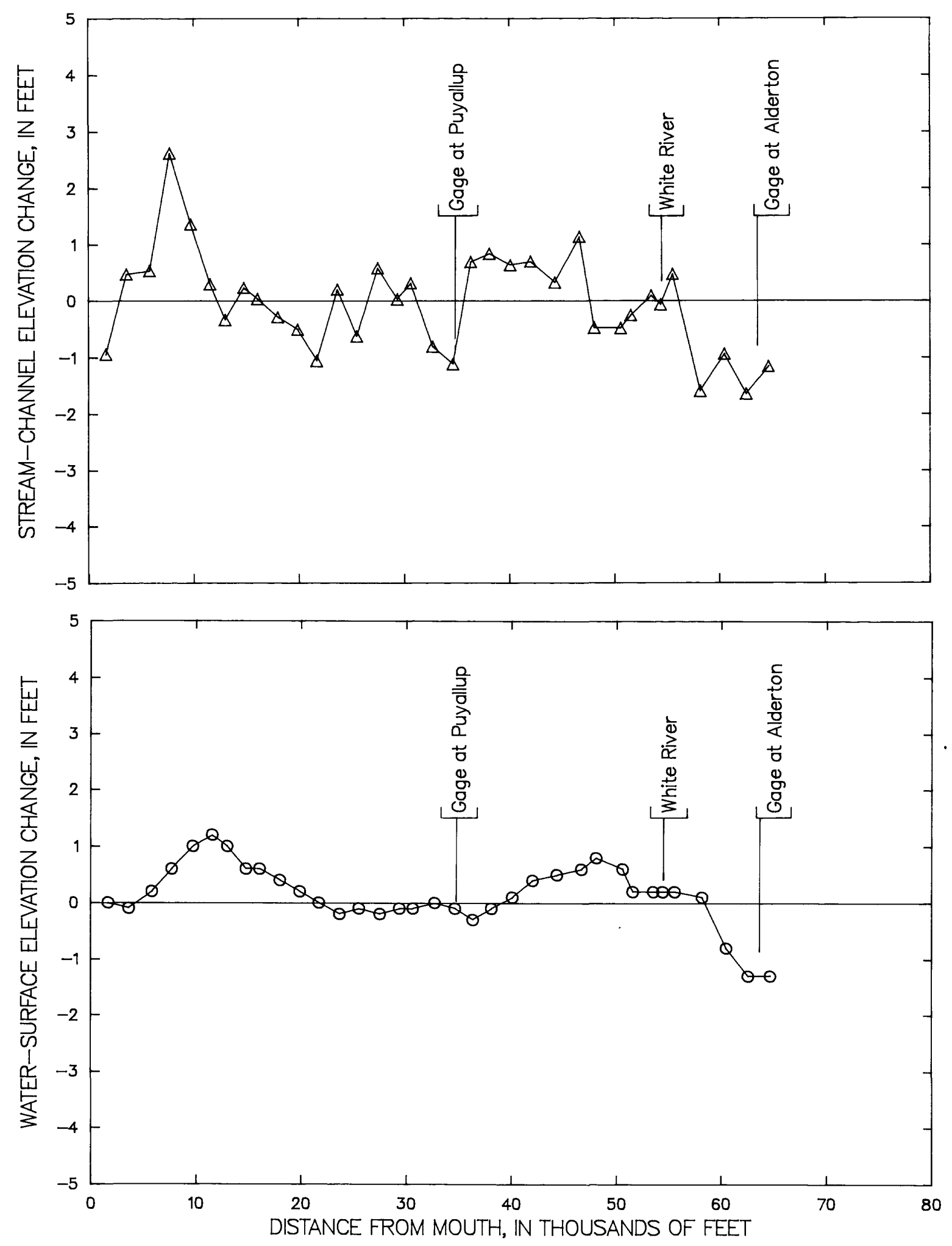

Figure 5.-Changes in average elevations of surveyed stream-channel cross sections (upper graph) and computed water-surface elevations for the 100-year flood (lower graph) from 1976-77 to 1984 for the lower Puyallup River. 

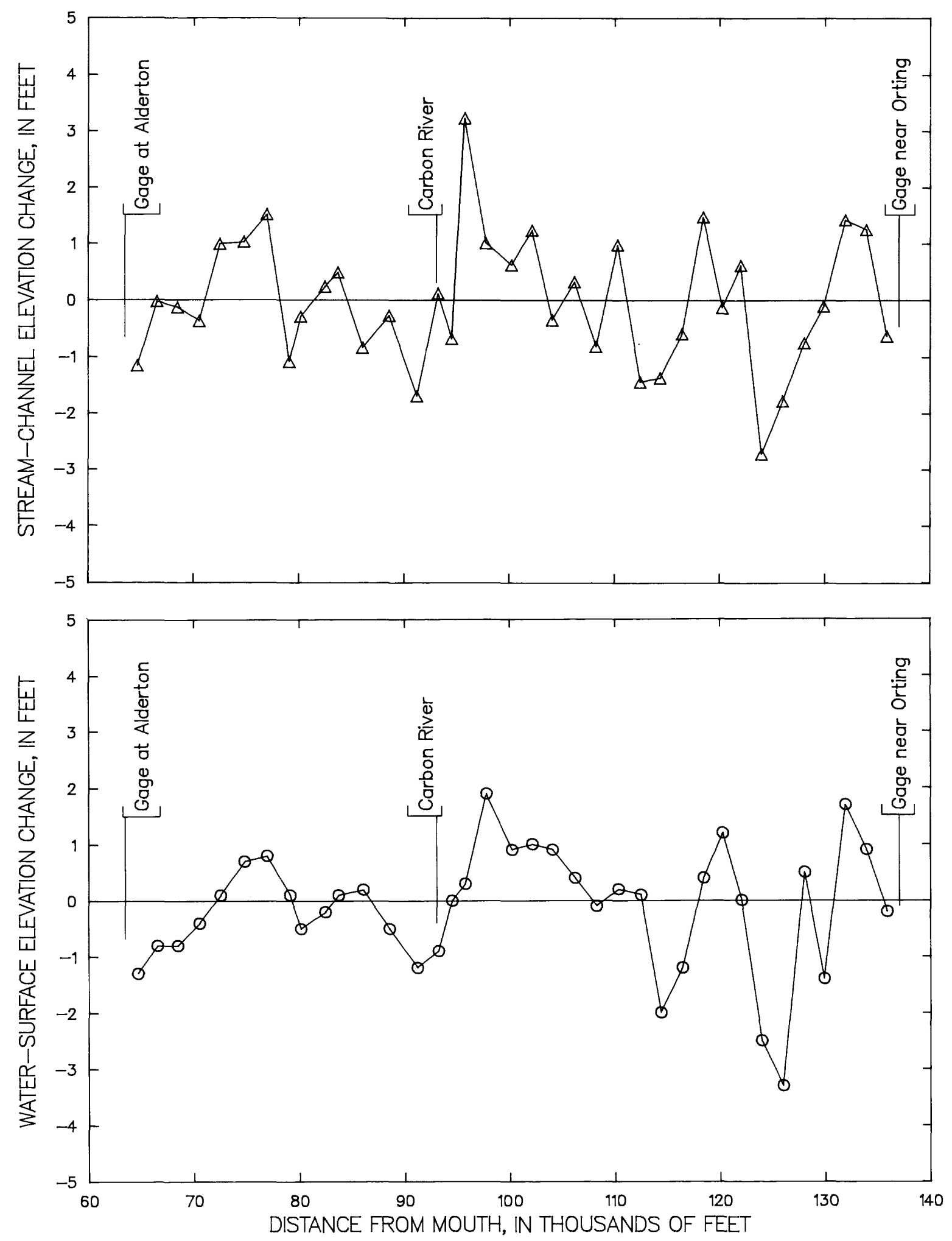

Figure 5.--Continued. 

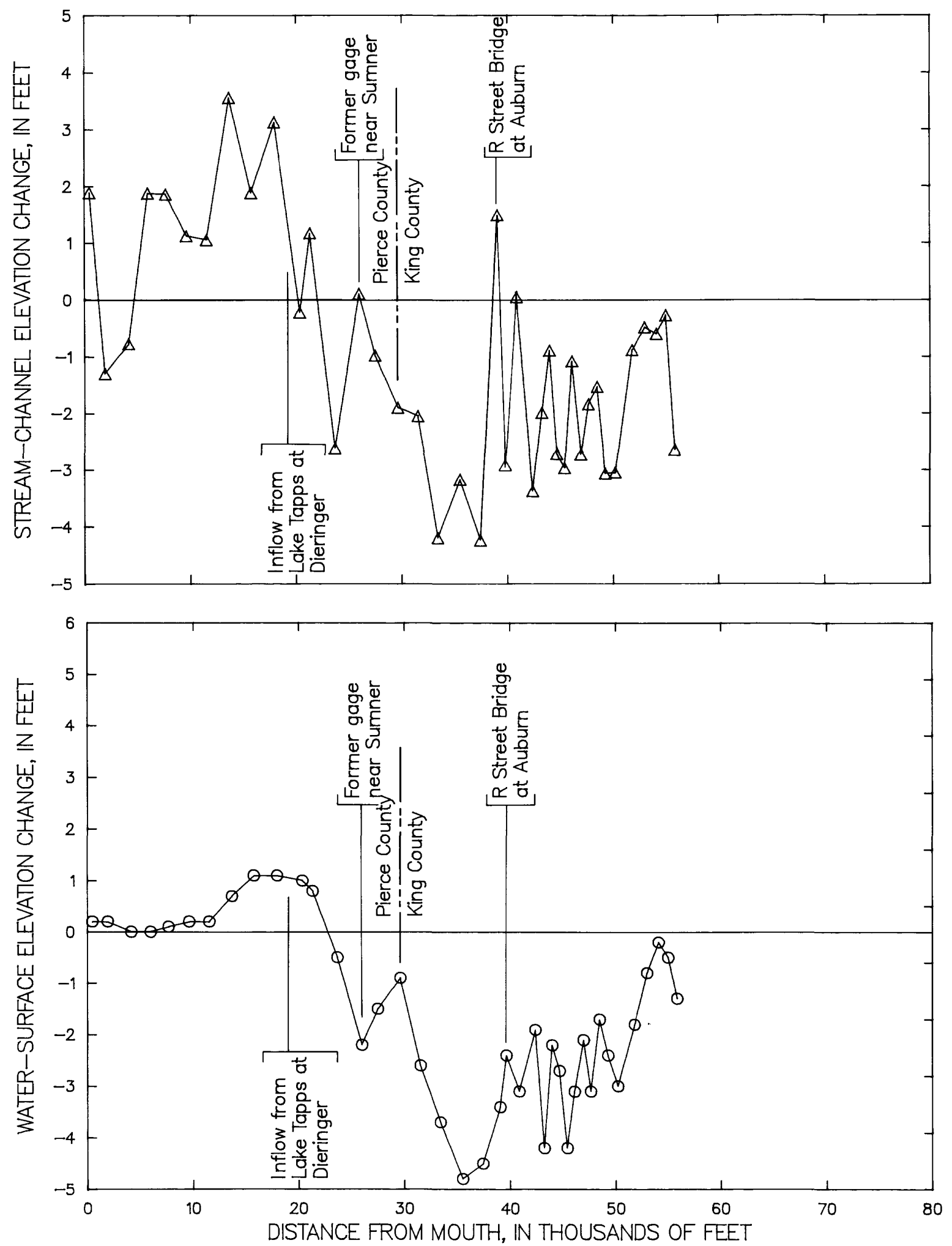

Figure 6.--Changes in average elevations of surveyed stream-channel cross sections (upper graph) and computed water-surface elevations for the 100-year flood (lower graph) from 1977 (Pierce County) or 1974 (King County) to 1984 for the lower White River. 

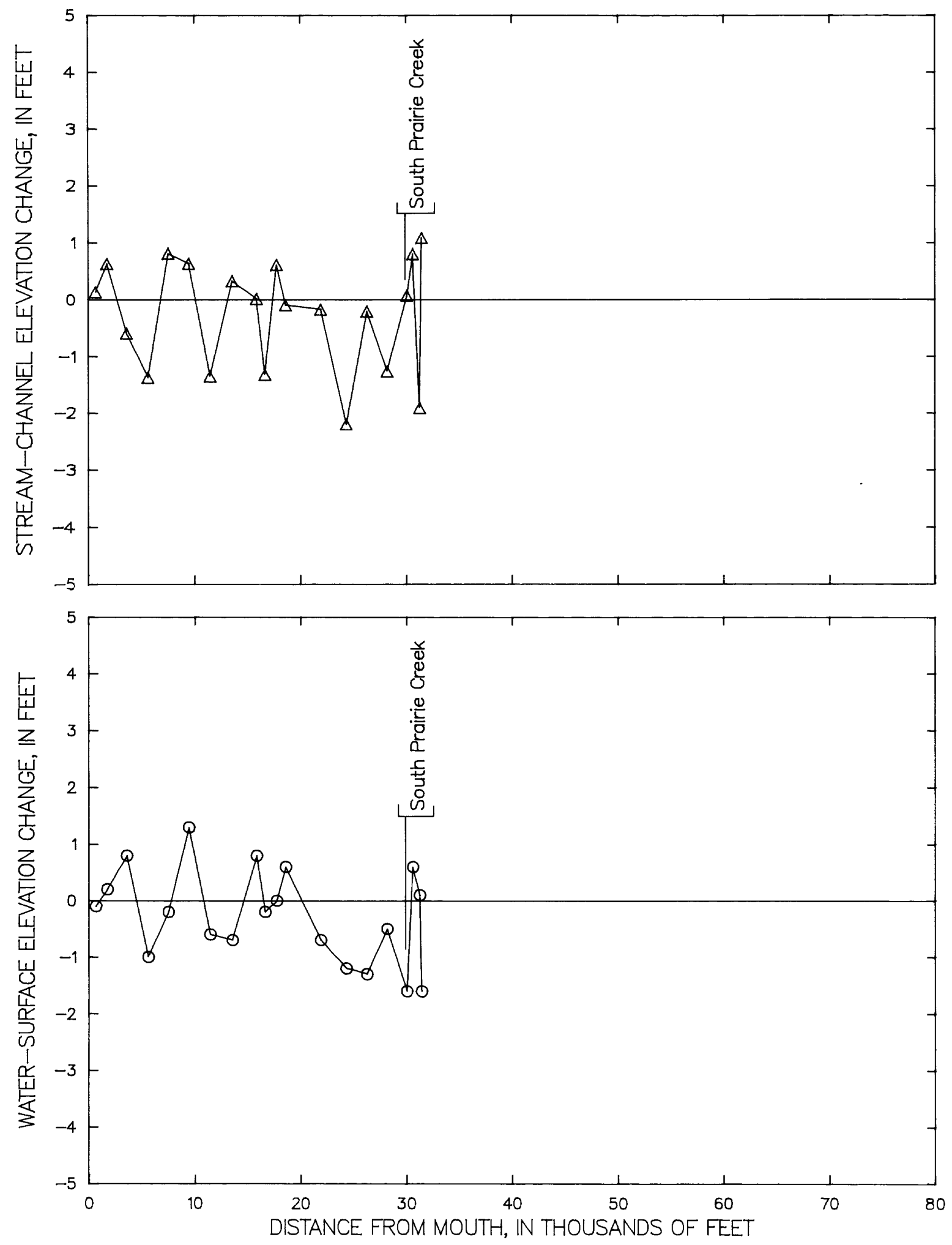

Figure 7.--Changes in average elevations of surveyed stream-channel cross sections (upper graph) and computed water-surface elevations for the 100-year flood (lower graph) from 1977 to 1984 for the lower Carbon River. 


\section{Carbon River}

Average cross-section elevation changes in the Carbon River (fig. 7) do not identify any reaches of channel aggradation or deepening. The absolute values of changes are less than 1 foot at more than one-half of the 20 cross sections and at no two adjacent cross sections are the changes greater than 1 foot and in the same direction. There are two cross sections at which the change nearly equals or exceeds 2 feet. Although the number of cross sections at which the changes are positive approximately equals the number at which they are negative, the magnitudes of the negative changes tend to be higher than those of the positive changes. Consequently, it is possible that during the period 1977 to 1984, there may have been a net lowering of the channel by an amount of 0.5 to 1 foot. However, this amount is less than the estimated accuracy of the computed elevation changes.

Changes in computed 100-year flood water-surface elevations are similar in magnitude and direction to changes in average channel elevation.

\section{Discussion}

When data in figures 5 through 7 indicate a change in channel elevation for the period 1974-77 to 1984, it should not be assumed that the change occurred continuously over the period of time between the surveys or that the average rate of changes will be the same in the future. Because most sediment movement usually occurs during brief periods of high discharge, it is possible (but by no means certain) that much of the change in channel elevation in the period between the 1984 and earlier surveys occurred during a few floods. Analyses of long-term data from gaging stations, in the following subsections, indicate that the time rate of change of channel elevation can vary in magnitude and direction.

Although the data in figures 5 and 7 do not identify any 1ong reaches of the Puyallup or Carbon Rivers with consistent changes in channel or 100-yearflood elevations, it should not be concluded that the transport of sediment into and out of the study area is in natural equilibrium. Because the 0.87 million cubic yards of sediment (table 1) removed from the channels from 1978 through 1983 was sufficient to lower all of the river channels in the study areas 0.4 foot, it is conceivable that larger rises in channel and 100-yearflood elevations could have occurred in some reaches if this sediment had not been removed.

The longitudinal variation in the change in computed 100-year-flood watersurface elevation was found to be less than the variation in change in average channel elevation, especially in the low-gradient downstream reaches of the White and Puyallup Rivers (figs. 5 through 7). The reason for this is that with subcritical flow, which is the flow regime in the river channels being studied, channel-elevation changes influence water-surface elevations at and upstream of where the changes occur. Consequently, the computed change in the water-surface elevation at a cross section represents an average of the effects of channel-elevation changes at a number of downstream cross sections. Therefore, effects of variations in changes in cross-section elevations on computed changes in water-surface elevations tend to be averaged or smoothed in lowgradient streams. 
The computed change in water-surface elevation at the mouths of the three rivers is near zero. This is so at the mouth of the Puyallup River because a water-surface elevation equal to that of mean higher high water in Commencement Bay was assumed at the mouth in both computations. The near-zero change at the mouths of the White and Carbon Rivers are both coincidences. For each of these tributaries the water-surface elevation at the mouth was set equal to the computed water-surface elevation in the Puyallup River at the confluence. The reason that the change in computed 100-year-flood elevation remains near zero in the White River for more than 10,000 feet upstream from its mouth is that maximum flood elevations in this reach are the result of backwater during peak discharges in the Puyallup River while discharges in the White River are being detained by Mud Mountain Dam.

\section{At Gaging Stations}

Water-surface elevations corresponding to the discharge that is exceeded 10 percent of the time is plotted as a function of time in figure 8 for each of four different gaging stations, three on the Puyallup River and one on the White River. Similar graphs for the Carbon River could not be made because no gaging station has been operated over an extended period of time on the study reach of this river. An increase in this water-surface elevation is indicative of an increase in the average channel elevation at a location not far downstream from the gage and, conversely, a decrease in this elevation is indicative of a decrease in channel elevation not far downstream of the gage.

\section{Puyallup River at Puyallup}

The gaging station on the Puyallup River at Puyallup has been operated to obtain continuous records, although not at exactly the same location, since 1913. Since 1955, water-surface elevations concordant with the 10-percent exceedence discharge at this station have been rising slowly but continuously for a total increase of about 0.5 foot (fig. 8). The change in water-surface elevation in the period between the two cross-section surveys, 1976-77 to 1984, was approximately +0.3 foot, while the change in computed 100 -year-flood elevation at the gage during this same period is -0.1 foot (fig. 5). The difference between the two changes, +0.3 and -0.1 foot, is less than the estimated accuracy of these computed values.

The record of concordant water-surface elevations before 1950 contains periods of relatively large changes. Elevations decreased about 5 feet during the 2-year period 1916 and 1917, and decreased another 3 feet during 1932 to 1934. The changes during the former period probably are a response to the extensive channel modifications following the establishment of the Inter-County River Improvement agency. The reason for the elevation changes in the latter period (1932-34) is unknown, but could perhaps be the result of gravel removed for construction of Highway 167 along the left bank of the river in the vicinity of the gage (David E. Lewis, Maintenance Supervisor, Inter-County River Improvement and Pierce County River Improvement, oral commun., 1986). A change in the location of the gage is at least partly the cause of the 5-foot change at the end of 1919. 

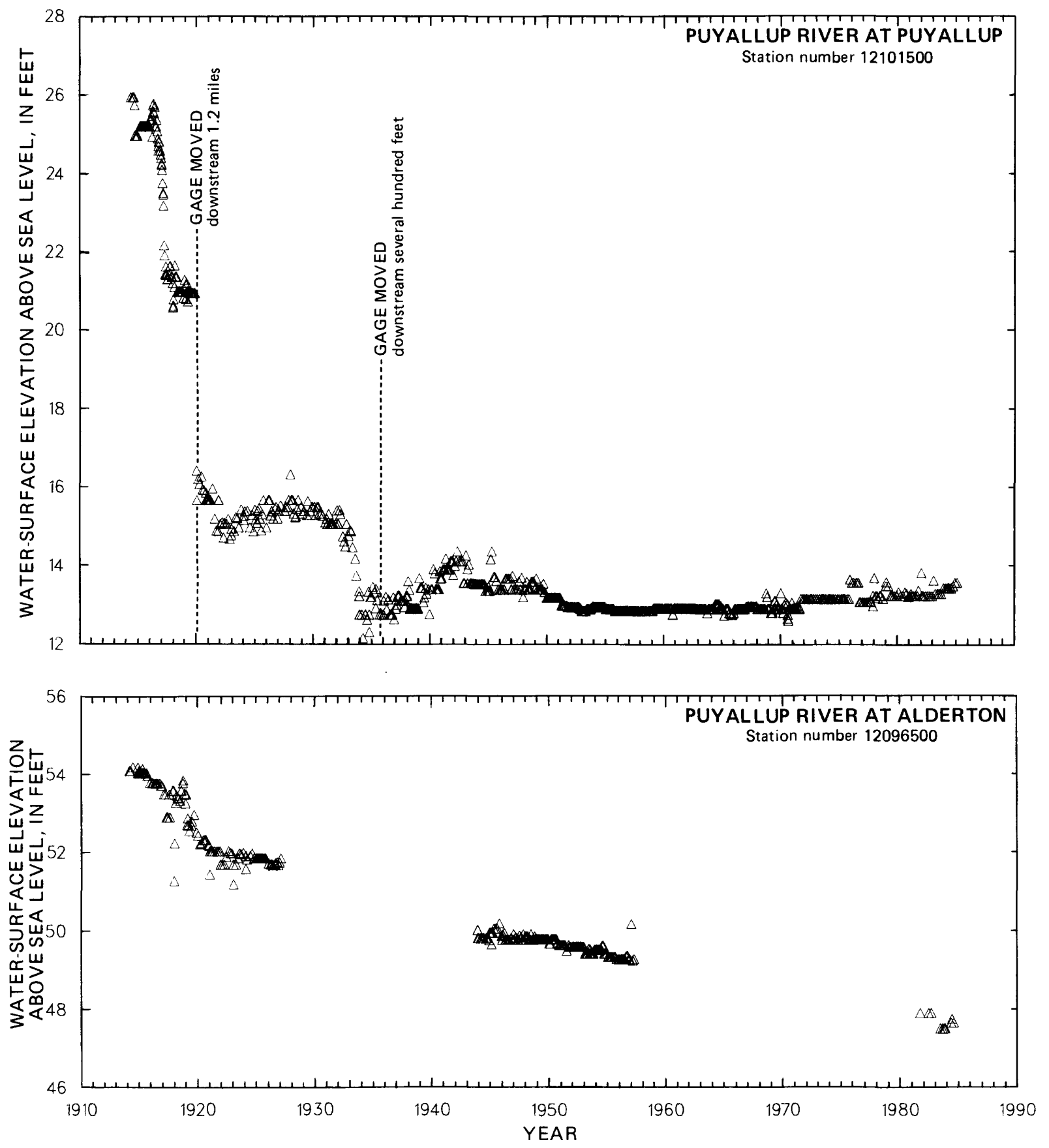

Figure 8.--History of water-surface elevations corresponding to discharges exceeded 10 percent of the time at gaging stations on the Puyallup River at Puyallup $(5,890 \mathrm{ft} / \mathrm{s})$, Puyallup River at Alderton $\left(2,800 \mathrm{ft}^{3} / \mathrm{s}\right)$. Puyallup River near Orting $\left(1,210 \mathrm{ft}^{3} / \mathrm{s}\right)$, and White River near Sumner $\left(1,800 \mathrm{ft}^{3} / \mathrm{s}\right)$. 

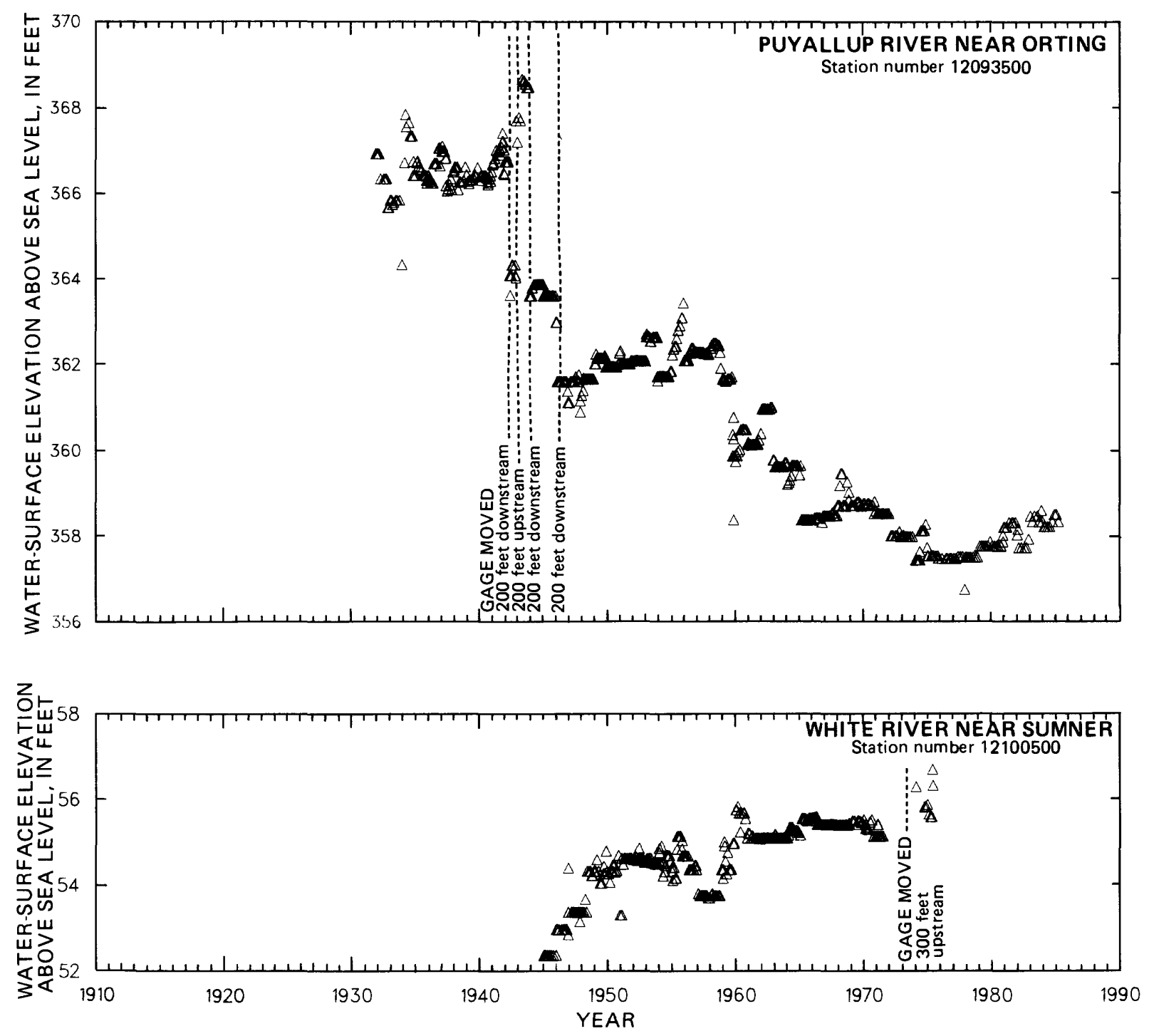

Figure 8.--Continued 


\section{Puyallup River at Alderton}

The gaging station on the Puyallup River at Alderton has been operated intermittently since 1914. During the first two periods of data collection, 1914 to 1926 and 1943 to 1957, the station was operated to collect continuous records. Most recently (since 1981) only miscellaneous measurements have been made at this site. The water-surface elevations concordant with the 10-percent exceedence discharge decreased almost continuously during the first two periods of station operation, and also had a net decrease during the two intervening periods when the station was inactive. The third period of station operation (1981 to 1984) is too short to indicate a trend. The rate of change in concordant water-surface elevation at this site was greatest (a decrease of about $0.4 \mathrm{ft} /$ year) in the 6 -year period 1915 to 1920 during and following the extensive channel work by ICRI, and probably was a consequence of this work. The reason for the slow and apparent continuous decrease (about $0.08 \mathrm{ft} /$ year) from 1920 through 1984 is unknown, but could be a continuing response to the early channel work and work done at later dates.

During the period 1977 to 1984 the concordant elevation change, estimated by interpolation between the data, was -0.5 foot. This amount is consistent with the calculated changes in average channel elevations downstream from the gage site, approximately -1.5 feet, and with the change in computed 100-yearflood elevation, -1.3 feet, at the gage for this same period (fig. 5).

\section{Puyallup River near Orting}

At the gaging station on the Puyallup River near Orting the water-surface elevation concordant with discharge that is exceeded 10 percent of the time has varied both up and down within about a 5-foot range since the gage was installed in 1931. Although the trend had been downward in the 20-year period 1955-75, the trend since 1980 appears to be upward. The most 11kely reason for much of the variation is the migration, growth, and shrinkage of gravel bars at or a short distance downstream of the gage. The pattern of short reaches with alternating aggradation and scour in the period 1977 to 1984 in the Puyallup River between the mouth of the Carbon River to the gage near Orting (fig. 5) is consistent with the idea of gravel-bar migration. The apparent decrease in water-surface elevation during the early 1940's is probably mostly a result of changes in the location of the gage.

During the period 1977 to 1984 , the concordant elevation rose 0.8 foot, indicating an increase in average channel elevation downstream of the gage. This amount cannot be compared with differences in surveyed cross-section elevations between the 1977 and 1984 surveys because the farthest upstream cross sections for which these data are avallable is 1,000 feet downstream of the gage. Because of the steepness of the channel, approximately 1 percent, channel changes this far below the gage have little effect on water-surface elevations at the gage. 


\section{White River near Sumner}

Water-surface elevations concordant with the 10-percent exceedence discharge at the gage on the White River near Sumner show an upward trend for most of the period of gage operation (1945 through 1977) with a small reversal from 1956 through 1959. Mosţ change appears to occur during a few years with relatively stable periods in between. The gage was not operating in the period 1977 to 1984, so these data cannot be compared with the changes in surveyed cross-section elevations. However, the 2.2-foot decrease in computed 100-yearflood elevation at the gage site for the period 1976-77 to 1984 is contrary to the apparent upward trend in concordant water elevations in previous years. The reason for this apparent discrepancy is not known, but could be a result of streambed gravel removal in the reach immediately upstream of the gage site. 


\section{EFFECTS OF STREAMBANK VEGETATION}

Because of the concern that uncontrolled growth of streambank vegetation could increase the hydraulic roughness of the river channels, resulting in increased water-surface elevations during floods, possible values of channel roughness with additional streambank vegetation were estimated by using empirical equations. These increased roughness values were used in computations of water-surface profiles for 100-year floods in 1984 channels with the banks or levees artificially raised to contain the flows. Differences between computed water-surface profiles with and without the increased roughness coefficients were then calculated.

For cross sections that were divided into two or more subareas for purposes of computation, each with its own value of roughness coefficient, the value of the coefficient for any potentially totally vegetated subarea was set equal to 0.10 .

For cross sections that are represented in the computations by a single area with a single effective roughness coefficient, the magnitudes of the increases in the coefficient due to dense vegetation on the banks were estimated through the use of equation 1 . This equation is based on the assumption that the effective roughness coefficient for an entire cross section, $n$, equals the area-weighted average of the values of the roughness coefficient for the streambed, $n_{b}$, and stream sides, $n_{s}$;

$$
n_{e}=\left(n_{b} A_{b}+n_{s} A_{s}\right) /\left(A_{b}+A_{s}\right)
$$

where $A_{b}$ and $A$ are the subareas associated with $n_{b}$ and $n_{s}$, respectively. (For an example of the use of equation 1 and the method of partitioning the cross section into subareas $A_{b}$ and $A_{s}$, see Cox, 1973.)

Consequently, the equation for $\Delta \mathrm{n}_{e}$, the change in $\mathrm{n}_{\mathrm{e}}$ caused by increasing $n_{s}$ by an amount $\Delta n_{s}$ can be derived from equation 1 to be

$$
\Delta n_{e}=\Delta n_{s} A_{s} /\left(A_{s}+A_{b}\right)
$$

In this study the values of the roughness coefficients for normal streambanks and densely vegetated streambanks were assumed to be 0.05 and 0.10 , respectively, which results in $\Delta \mathrm{n}_{\mathrm{s}}=0.05$.

An upper limit of 0.003 was imposed on the value of $\Delta \mathrm{n}$ given by equation 2. This limit is based on a recommendation by Arcement and Schneider (1984, p. 12) who suggest that the maximum effect of streambank vegetation on the effective roughness coefficient for wide channels is 0.005 . This number was reduced to 0.003 because of the relatively large estimated roughness coefficient of the normal streambanks (0.05). 
In applying this method to the river channels of the lower Puyallup basin equation 2 was used on a random sample of about 20 percent of the cross sections in each of six reaches. The average of the increases, $n_{e}$, for a reach was used for all cross sections in the reach.

The estimated average increase in the roughness coefficient for a reach ranges from 0.001 to 0.003 (table 6), which is an increase of 3 to 10 percent of the original value. The largest increases are for the Puyallup and lower White Rivers where the width-to-depth ratios are smaller than in the Carbon or upper White River. As the numerical value of this ratio decreases the effects of bank roughness increase. The estimated increase in water-surface elevation (table 6) for the 100-year flood resulting from the increase in roughness is largest in the lower reaches of the Puyallup and White Rivers (up to 1.2 and 0.9 feet, respectively). In the Carbon and upper White Rivers, where the width-to-depth ratios are largest, the estimated increases in water-surface elevations are 0.2 foot or less. The magnitude of increases in water-surface elevations caused by uniform streambank vegetation should decrease with decreasing magnitudes of the flood discharge.

Because there are no quantitative data on the amounts of streambank vegetation that existed in 1984 or in 1974-77, the values of the differences in channel roughness and water-surface elevations given in table 5 only serve as indications of how much these quantities might increase as a result of an increase in density of vegetation.

TABLE 6.--Estimated increases in values of effective Manning's roughness coefficient at cross sections and in computed water-surface elevations for 100 -year floods in 1984 channels due to assumed increased density of streambank vegetation

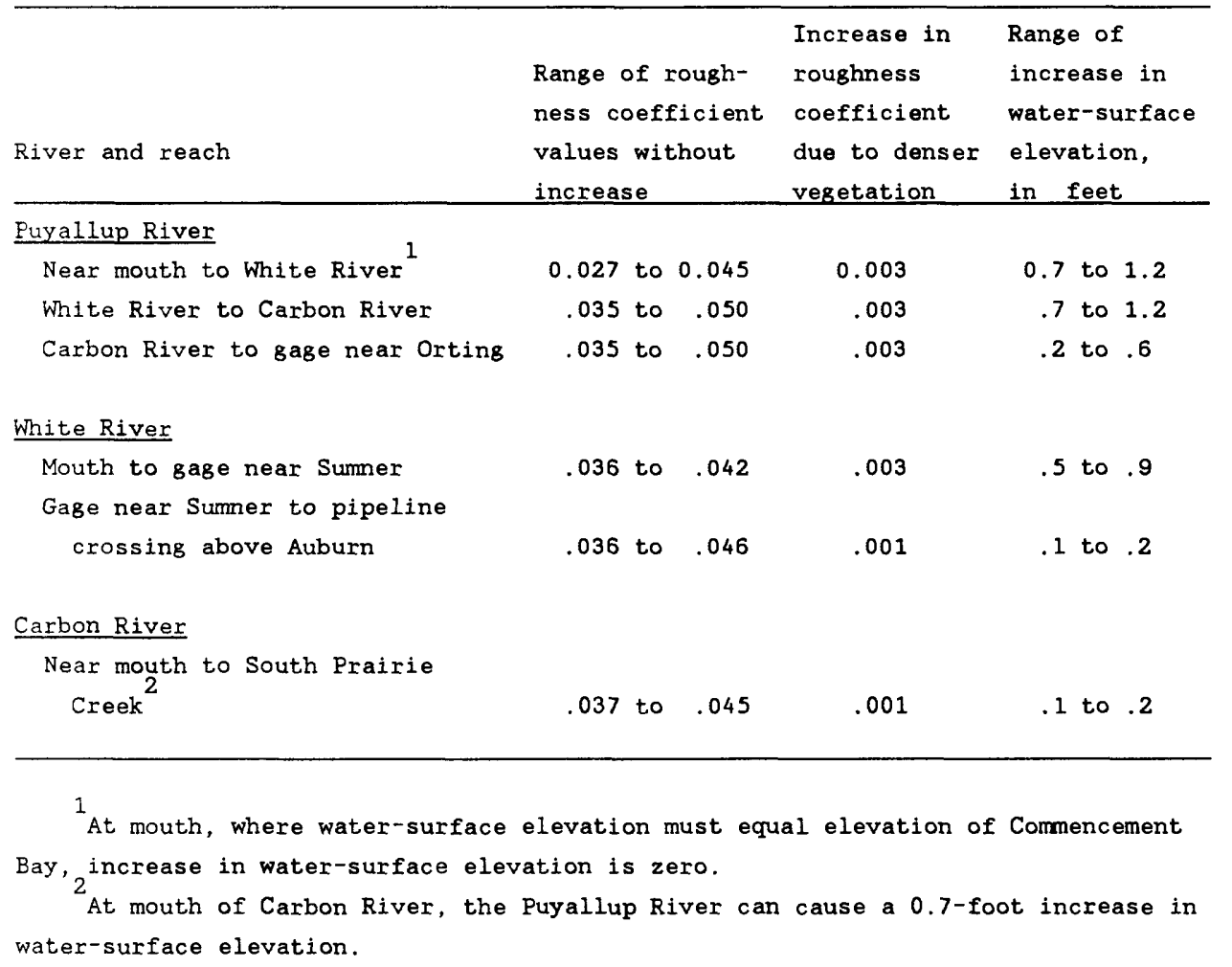




\section{SUMMARY AND CONCLUSIONS}

Surveys were made in the summer of 1984 to define the shape and elevation of 132 cross sections in the downstream-most 26 miles of the Puyallup River, 10 miles of the White River, and 6 miles of the Carbon River. These cross sections were surveyed as close in location as possible to cross sections surveyed in 1974-77. The data from the two surveys were used to compute watersurface elevations for floods of various magnitudes and average elevations of the river channel at each cross section.

The flood-carrying capacity of a river channel at a cross section was defined as the discharge for which the computed elevation of the water surface is equal to the surveyed elevation at the top of the riverbank, or in the case of a raised levee, 3 feet below the top of the levee. In the reach of the Puyallup River from its mouth to the city of Puyallup, the flood-carrying capacity equals or exceeds the 100-year-flood discharge at all but a few cross sections. At all but one of these cross sections there is between 2 and 3 feet of freeboard for the 100-year flood. In the reach of the Puyallup River extending from the city of Puyallup to the stream-gaging station upstream from Orting, the channel-carrying capacity is less than the 100-year flood at many of the cross sections. At some of the cross sections, near the city of orting for example, computed water-surface elevations are above the tops of the levees.

The flood-carrying capacity at nearly all the surveyed cross sections of the White River in Pierce County is less than the 100-year-flood discharge. The computed flood-carrying capacity of the White River channel in King County is greater than the 100-year flood at nearly all the surveyed cross sections. However, because of washed-out sections of the left (facing downstream) levee at a number of locations upstream of the $R$ Street bridge at Auburn, the White River inundates areas on the landward side of that levee almost every year.

The flood-carrying capacity of the Carbon River is less than the 100-year flood at about one-half of the surveyed cross sections. Near its mouth and near the mouth of South Prairie Creek, the water-surface elevations would overtop the levees during a 100-year flood.

Data on changes in average channel elevations of cross sections on the Puyallup and Carbon Rivers between 1976-77 and 1984 do not define any reaches where the channel has significantly aggraded or deepened. The observed changes were less than 1 foot at more than half of the 70 cross sections on the Puyallup River and were also less than 1 foot at more than half the 20 cross sections on the Carbon River. Changes nearly equaled or exceeded 2 feet at only three cross sections on the Puyallup River and two on the Carbon River. The accuracy of the observed changes is probably in the range 1 to 2 feet.

The average change in cross-section elevation was about +2 feet or more at 5 out of 10 cross sections on the White River in the reach between the mouth and the inflow from Lake Tapps at Dieringer; this indicates an aggrading channel in this reach. In the reach between the former gage site near sumner and the upstream end of the study area, the channel has deepened. The decrease in average channel elevation exceeds 2 feet at many cross sections in this reach, and at two of the cross sections downstream of the $R$ Street bridge 
at Auburn, the decrease is about 4 feet. The decreases in channel elevations may have been caused by gravel removal by contractors.

Differences between the computed water-surface profiles for the 100-year flood in 1984 and in 1976-77 or 1974 channels were similar in direction and magnitude to differences in average elevations of cross sections of these channels. However, the variation of flood elevations between cross sections was less than the variation in average channel elevation, especially in the low-gradient downstream reaches of the river. Differences in 10-and 50-year flood elevations were within 0.5 foot of the differences for the 100-year flood.

The amount of sediment removed from the river channels by Pierce County and Inter-County River Improvement and by private contractors in the period between the surveys was more than sufficient to lower all the river channels in the study area by 0.4 foot. If this sediment had not been removed, larger increases in channel and 100-year-flood elevations might have occurred at some cross sections.

Long-term histories of water-surface elevations corresponding to single discharges at gaging stations were also investigated. Water-surface elevations that correspond to discharges that are exceeded 10 percent of the time were plotted against time for the four gaging stations in the study area. An increase or decrease in the water-surface elevation is an indication that the channel is aggrading or deepening, respectively, in a nearby reach downstream of the gage.

Water-surface elevations that correspond to a discharge of $5,890 \mathrm{ft}^{3} / \mathrm{s}$ in the Puyallup River at Puyallup decreased about 5 feet during 1916 to 1917, and another 3 feet during 1933 to 1934. The decreases during the first and perhaps the second of these periods were in response to major channel modifications by Inter-County River Improvement. Since about 1950 the corresponding elevations have been rising slowly but continuously. From 1977 to 1984 the rise in elevation was approximately 0.3 foot.

Water-surface elevations corresponding to a discharge of $2,800 \mathrm{ft}^{3} / \mathrm{s}$ in the Puyallup River at Alderton decreased nearly continuously by approximately 6 feet during the periods of intermittent station operation from 1914 through 1984. The rate of decrease since 1920 has been relatively steady at approximately 0.08 foot per year, but in the 6 years before 1920, during the period of extensive channel modification, the rate of decrease was about 5 times as great. The decrease from 1977 to 1984 is estimated to be about 0.5 foot, which agrees, within the expected accuracy, with the computed decrease of 1.3 feet in the 100-year-flood elevation at the site.

Water-surface elevations corresponding to a discharge of $1,210 \mathrm{ft}^{3} / \mathrm{s}$ in the Puyallup River at the gage near Orting varied both up and down within about a 5-foot range since the gage was installed in 1931 . No long-term trends are evident. The changes are probably caused by the migration, growth and decay of gravel bars in the vicinity of the gage. 
Water-surface elevations corresponding to a discharge of $1,800 \mathrm{ft}^{3} / \mathrm{s}$ in the White River at the former gage near Sumner increased approximately 2 feet during the first 5 years of gage operation, 1945 to 1950 , but increased only another 2 feet in the following 25 years, 1950 to 1975 , when the gage was discontinued. However, a decrease of 2.5 feet in computed 100-year-flood water-surface elevation from 1977 to 1984 suggests a reversal of this upward trend in recent years, perhaps a result of gravel removal in the reach above the gage.

The possible increases in 100-year-flood water-surface elevations that could be caused by a dense growth of streambank vegetation were estimated to be from 0.7 to 1.2 foot at locations on the Puyallup River between its mouth and the Carbon River and from 0.2 and 0.6 upstream of its confluence with the Carbon River. In the White River, from its mouth to the former gage near Sumner, the range of increase was 0.5 to 0.9 foot. In the White River above the gage and in the entire Carbon River study reach the increase was equal to or less than 0.2 foot. These increases were computed by estimating the amounts that vegetation could increase the hydraulic roughness coefficients and recomputing the water-surface profiles for the 100 -year floods using the new coefficients.

\section{REFERENCES CITED}

Arcement, G. J., Jr, and Schneider, V. R., 1984, Guide for selecting Manning's roughness coefficient for natural channels and flood plains: U.S. Federal Highway Administration, Report No. FHWA-TS-84-204, 62 p.

Cooper, R. H., 1983, Effects of Mud Mountain Dam regulation on sediment movement in the White River: Northwest Hydraulic Consultants, Inc., Kent, Washington, $51 \mathrm{p}$.

Cox, R. G., 1973, Effective hydraulic roughness for channels having bed roughness different from bank roughness: U.S. Army Engineers Waterways Experiment Station, Miscellaneous Paper H-73-2, 57 p.

Federal Emergency Management Agency, 1985, Guidelines and specifications for study contractors: Report FEMA-37/September 1985, $145 \mathrm{p}$.

Inter-County River Improvement Commission, 1936, Annual report of the Engineers: $30 \mathrm{p}$.

Shearman, J. 0., 1976, Computer applications for step-backwater and flooding analyses, Computer Program E431 Users Manual: U.S. Geological Survey Open-file Report 76-499, 103 p.

U.S. National Oceanic and Atmospheric Administration, 1978, Climatological data for Washington: v. 82, no. 13, Ashville, North Carolina.

U.S. Water-Resources Council, 1981, Guidelines for determining flood flow frequency: Bulletin no. 17B of the Hydrology Committee, $183 \mathrm{p}$. 
$\begin{array}{llllllll}\text { A } & \mathbf{P} & \mathbf{P} & \mathbf{E} & \mathbf{N} & \mathbf{D} & \mathbf{I} & \mathbf{X}\end{array}$ 
TABLE A1.--Elevations for 1984 of tops of banks or lovees, of thalwegs, and of computed water surfaces for floods of various magnitude at cross sections of the lower Puyallup River. All water-surface elevations computed with flow confined between banks or levees. Water discharges are given at the bottom of the table

Elevations, in feet above sea lovel

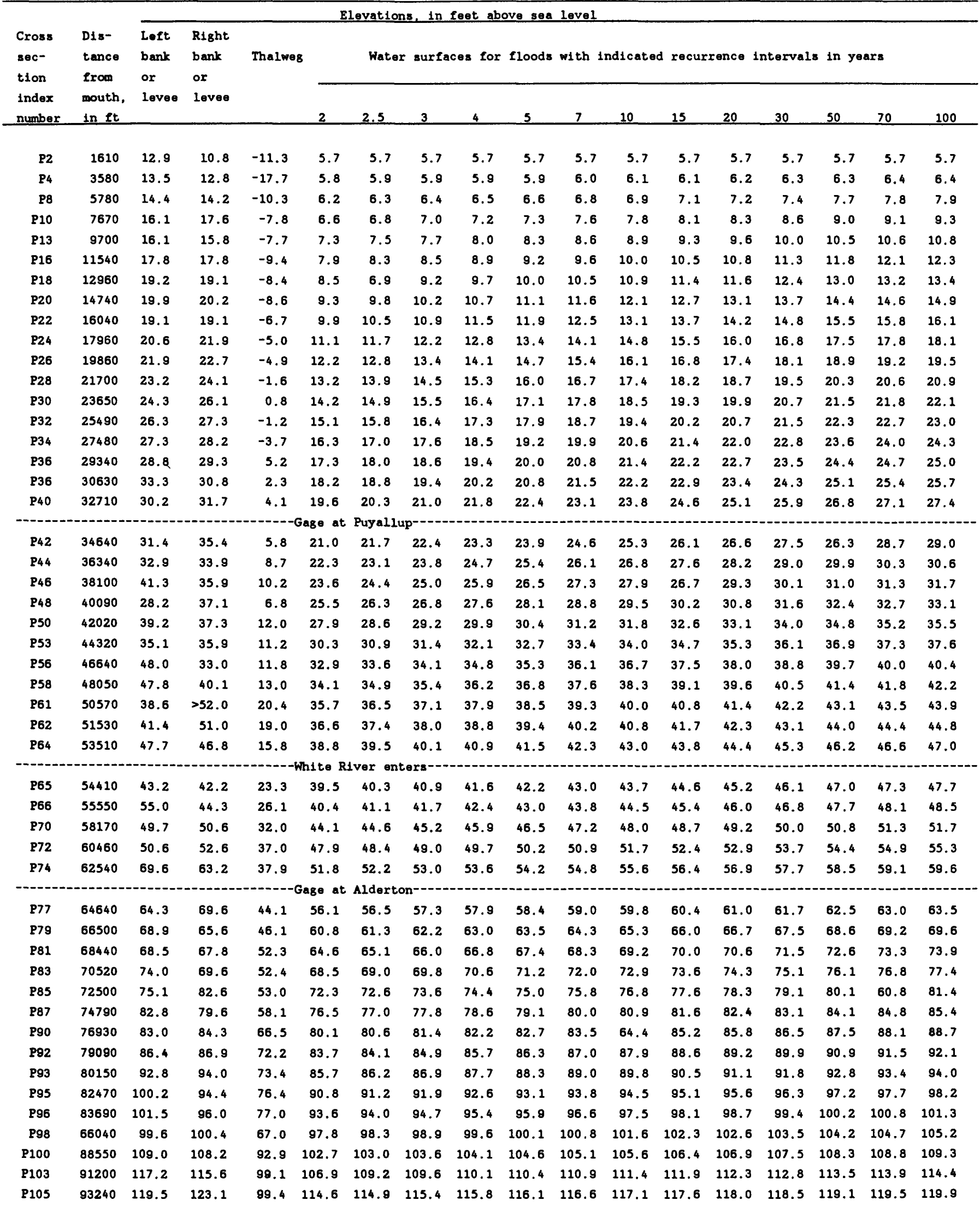


TABLE A1.- Continued

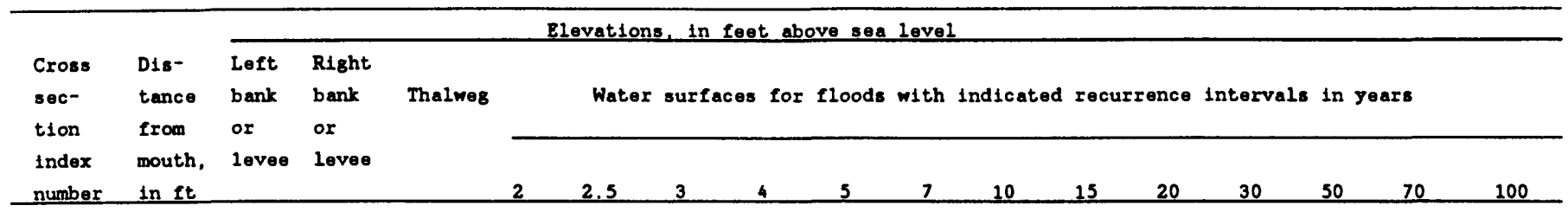

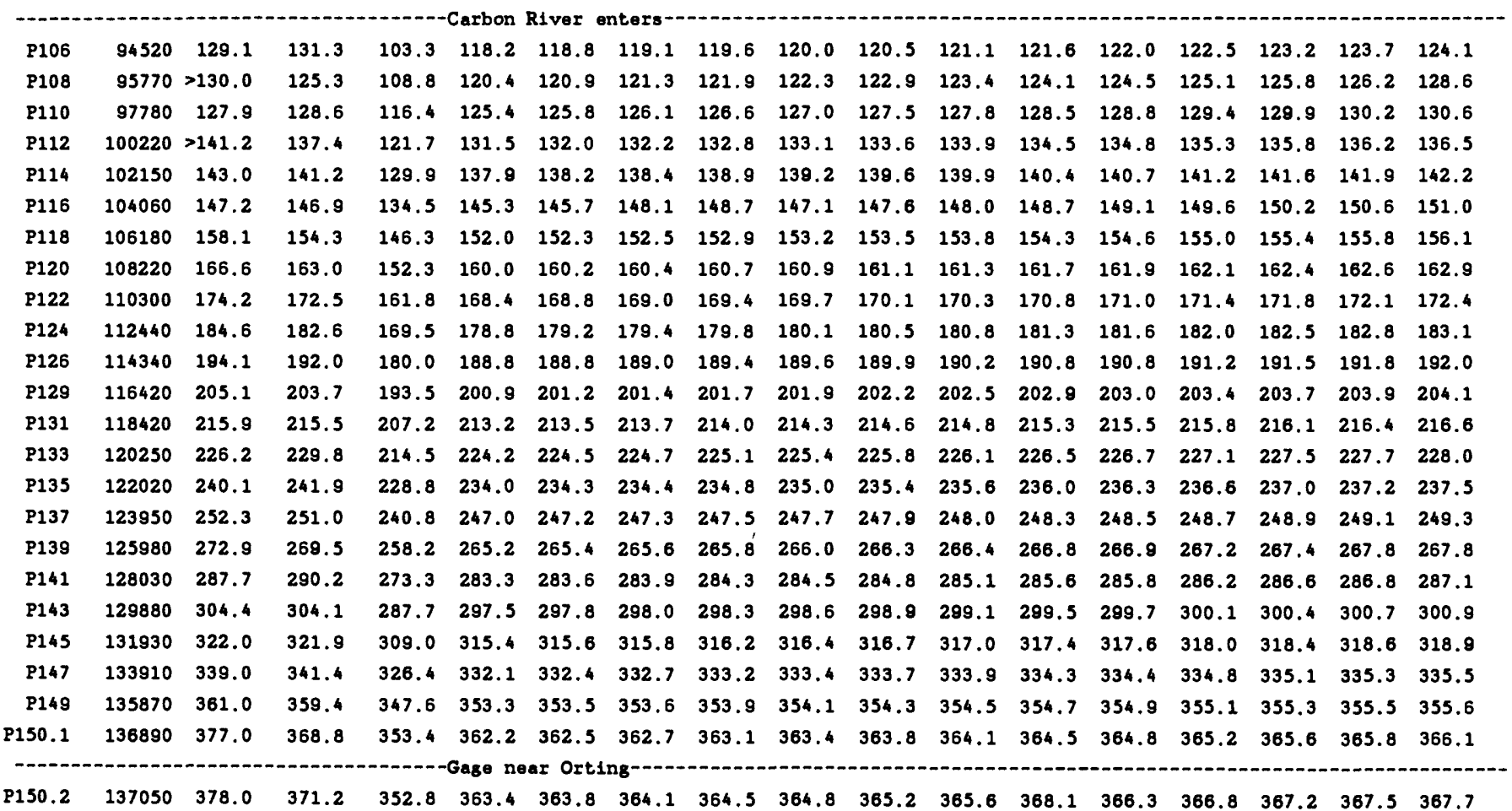

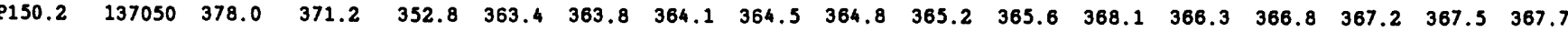

Discharges, in cubic feet per second, at indicated recurrence intervals

P2 to P64

P65 to P105

P106 to P150.2 $\begin{array}{lllllllllllll}22000 & 24100 & 25800 & 28100 & 30000 & 32600 & 35000 & 38000 & 40200 & 43500 & 47000 & 48500 & 50000\end{array}$

$\begin{array}{lllllllllllll}13200 & 14200 & 15900 & 17600 & 18900 & 20700 & 23000 & 25000 & 26700 & 29000 & 32000 & 34000 & 36000\end{array}$

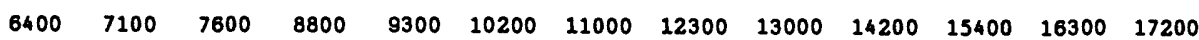


TABLE A2.--Elovations for 1984 of tops of banks or levees, of thalwegs, and of computed water surfaces for floods of various magnitudes at cross sections of the lower White River. All water-surface elevations computed with flow confined between banks or levees. Water discharges are given at the bottom of the table

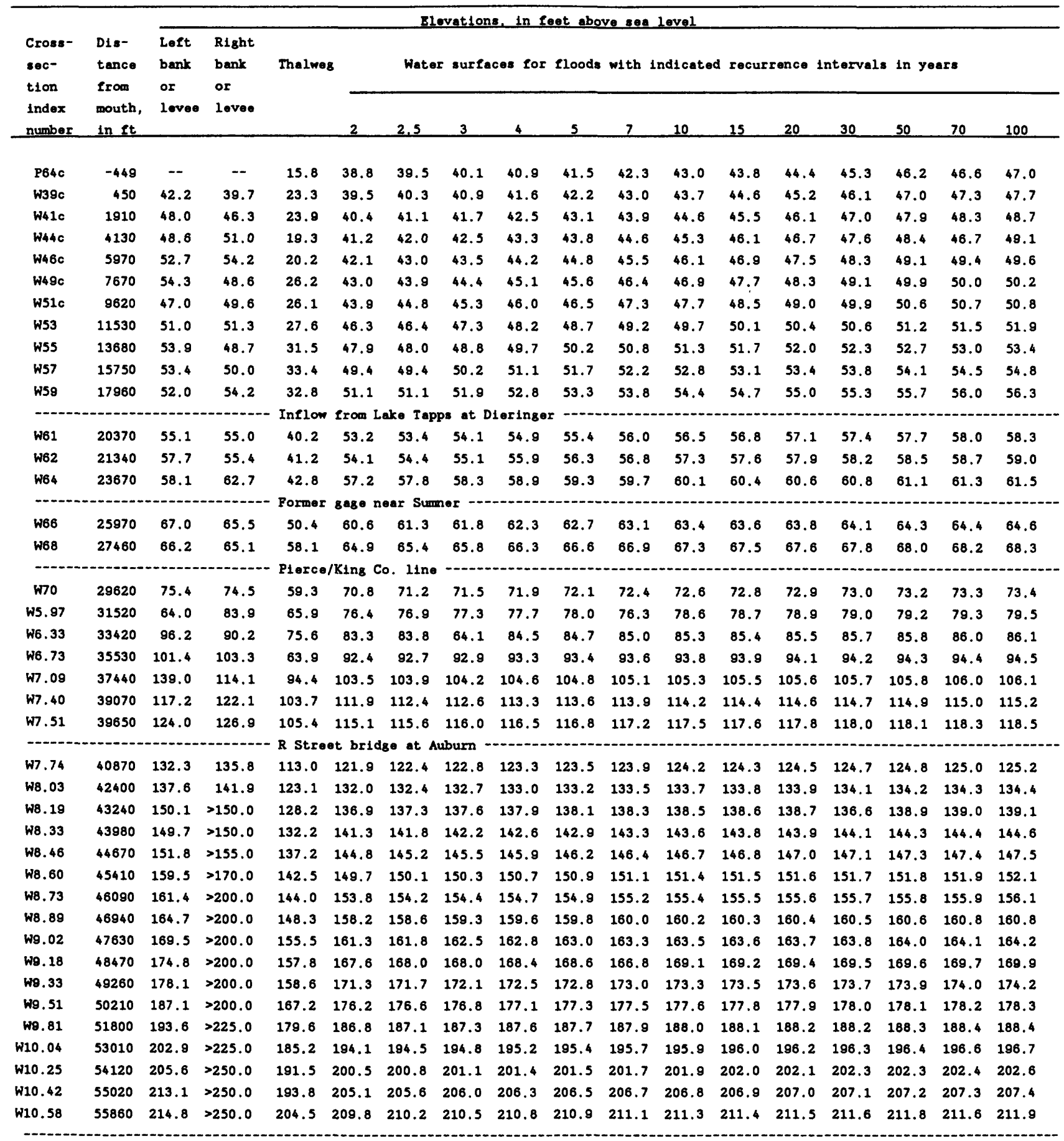

Discharges, in cubic feet per aecond, at indicated recureence intervals

P64

W39 to during peak discharge

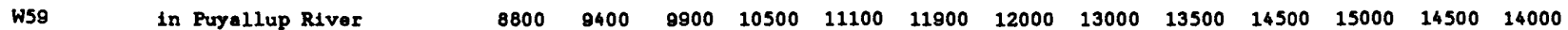

P64 $2000020100211002240023200 \quad 24100 \quad 25000 \quad 27500 \quad 29300 \quad 31600340003540037000$

W39 to during peak discharge

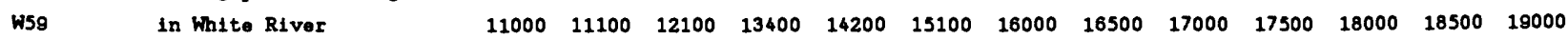

W61 to

W10.58

$\begin{array}{lllllllllllll}22000 & 24100 & 25800 & 28100 & 30000 & 32600 & 35000 & 38000 & 41200 & 43500 & 47000 & 48500 & 50000\end{array}$

$\begin{array}{lllllllllllll}20000 & 20100 & 21100 & 22400 & 23200 & 24100 & 25000 & 27500 & 29300 & 31600 & 34000 & 35400 & 37000\end{array}$

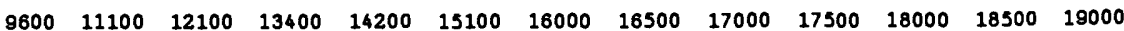

- Maximum water levela at these cross aections caused by backwater during peak discherges in Puyallup River. 
TABLE A3.--Elevations for 1984 of tops of banks or levees, of thalwegs, and of computed water aurfaces for floods of various magnitudes at cross sections of the lower Carbon River. All water-gurface elevations computed with flow confined between banks or levees. Water diecharges ere given at the bottom of the table

Elevations, in foet above sea level

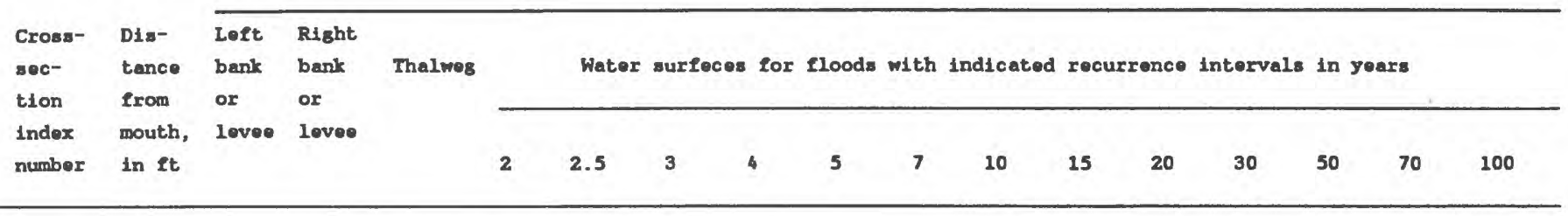

\begin{tabular}{|c|c|c|c|c|c|c|c|c|c|c|c|c|c|c|c|c|c|}
\hline P105 & -439 & -- & -- & 99.4 & 114.6 & 114.9 & 115.4 & 115.8 & 116.1 & 116.6 & 117.1 & 117.6 & 118.0 & 118.5 & 119.1 & 119.5 & 119.9 \\
\hline C1 & 640 & 123.0 & 127.3 & 109.8 & 118.5 & 119.0 & 119.3 & 119.8 & 120.1 & 120.6 & 121.1 & 121.6 & 122.0 & 122.6 & 123.2 & 123.6 & 124.0 \\
\hline $\mathrm{C} 2$ & 1720 & 129.1 & 130.1 & 114.4 & 122.9 & $123.3^{\prime}$ & 123.5 & 124.0 & 124.3 & 124.7 & 125.2 & 125.6 & 126.0 & 126.5 & 127.0 & 127.3 & 127.8 \\
\hline $\mathrm{CH}_{4}$ & 3570 & 133.2 & 135.7 & 122.2 & 131.5 & 131.8 & 132.1 & 132.5 & 132.8 & 133.2 & 133.6 & 134.0 & 134.3 & 134.7 & 135.7 & 136.0 & 136.4 \\
\hline C6 & 5590 & 142.9 & 143.8 & 131.9 & 139.2 & 139.5 & 139.8 & 140.3 & 140.5 & 141.0 & 141.5 & 141.9 & 142.3 & 142.8 & 143.6 & 144.0 & 144.4 \\
\hline C8 & 7490 & 154.9 & $>158.0$ & 141.8 & 149.9 & 150.2 & 150.4 & 150.7 & 150.9 & 151.2 & 151.6 & 151.6 & 152.1 & 152.4 & 152.7 & 153.0 & 153.4 \\
\hline C10 & 9440 & 163.8 & $>167.0$ & 147.2 & 157.7 & 158.2 & 158.5 & 159.0 & 159.4 & 159.9 & 160.5 & 161.0 & 161.5 & 162.0 & 162.8 & 163.2 & 163.8 \\
\hline $\mathrm{Cl2}$ & 11450 & 174.4 & $>178.0$ & 159.2 & 165.4 & 165.8 & 166.0 & 166.7 & 166.9 & 167.3 & 167.7 & 166.0 & 166.3 & 168.7 & 169.2 & 169.5 & 170.0 \\
\hline C14 & 13550 & 183.0 & $>186.0$ & 167.6 & 176.3 & 176.6 & 176.8 & 177.3 & 177.5 & 177.8 & 176.1 & 178.4 & 178.7 & 179.0 & 179.3 & 179.5 & 178.8 \\
\hline $\mathrm{C16}$ & 15840 & 192.7 & $>195.0$ & 177.9 & 186.3 & 186.7 & 186.9 & 187.3 & 187.5 & 186.0 & 188.5 & 188.9 & 189.3 & 189.8 & 190.3 & 190.7 & 191.2 \\
\hline C17 & 16630 & 198.0 & $>200.0$ & 163.0 & 188.8 & 190.1 & 190.3 & 190.7 & 180.9 & 191.3 & 191.7 & 192.1 & 182.5 & 192.8 & 193.4 & 193.8 & 194.3 \\
\hline C18 & 17730 & 203.1 & $>206.0$ & 191.6 & 197.3 & 197.4 & 197.5 & 197.6 & 197.8 & 197.8 & 198.2 & 198.2 & 188.3 & 196.5 & 196.7 & 198.8 & 199.1 \\
\hline C19 & 18580 & 206.7 & 206.7 & 195.1 & 203.4 & 203.7 & 203.8 & 204.1 & 204.3 & 204.6 & 204.8 & 205.2 & 205.4 & 205.7 & 205.9 & 206.1 & 206.3 \\
\hline $\mathrm{C} 22$ & 21900 & 231.0 & $>230.0$ & 217.3 & 223.4 & 223.6 & 223.8 & 224.0 & 224.2 & 224.5 & 224.8 & 224.9 & 225.1 & 225.3 & 225.6 & 225.8 & 226.1 \\
\hline $\mathrm{C} 24$ & 24310 & 247.0 & $>250.0$ & 236.1 & 243.2 & 243.5 & 243.8 & 244.1 & 244.4 & 244.7 & 245.0 & 245.4 & 245.7 & 246.0 & 246.3 & 246.5 & 246.8 \\
\hline C26 & 26250 & 262.7 & $>265.0$ & 247.2 & 255.8 & 256.1 & 256.2 & 256.5 & 256.7 & 256.9 & 257.3 & 257.5 & 257.7 & 258.0 & 258.4 & 258.7 & 259.0 \\
\hline C28 & 28160 & 279.6 & 261.1 & 262.5 & 270.4 & 270.8 & 271.0 & 271.3 & 271.5 & 271.8 & 272.0 & 272.3 & 272.5 & 272.7 & 273.0 & 273.1 & 273.4 \\
\hline C30 & 30030 & 294.1 & $>300.0$ & 276.0 & 287.3 & 287.8 & 288.1 & 288.5 & 268.8 & 289.2 & 289.7 & 289.9 & 290.3 & 290.6 & 291.1 & 291.4 & 291.8 \\
\hline C31 & 30600 & 299.4 & 298.8 & 285.3 & 293.9 & 294.3 & 294.5 & 294.9 & 295.1 & 285.5 & 295.8 & 296.3 & 296.6 & 297.0 & 297.4 & 297.7 & 298.1 \\
\hline C32 & 31260 & 302.8 & 303.2 & 291.0 & 298.2 & 296.6 & 298.9 & 299.3 & 299.6 & 300.0 & 300.4 & 300.8 & 301.2 & 301.8 & 302.2 & 302.7 & 303.0 \\
\hline C33 & 31450 & 310.0 & 308.8 & 297.3 & 301.7 & 301.9 & 302.0 & 302.2 & 302.4 & 302.6 & 302.8 & 303.1 & 302.8 & 303.3 & 303.7 & 304.1 & 304.4 \\
\hline
\end{tabular}

Discharges, in cubic loet per second, at indicated recurrence intervals

P105

C1 to $\mathbf{c 3 0}$

C31 to c33

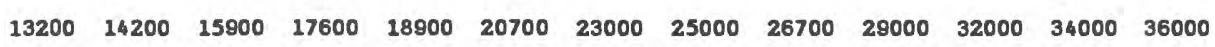

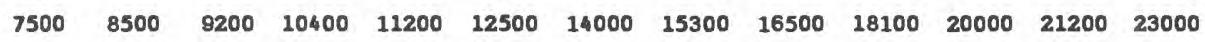

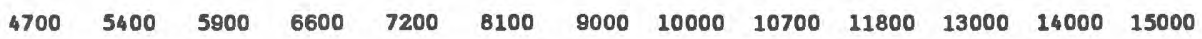




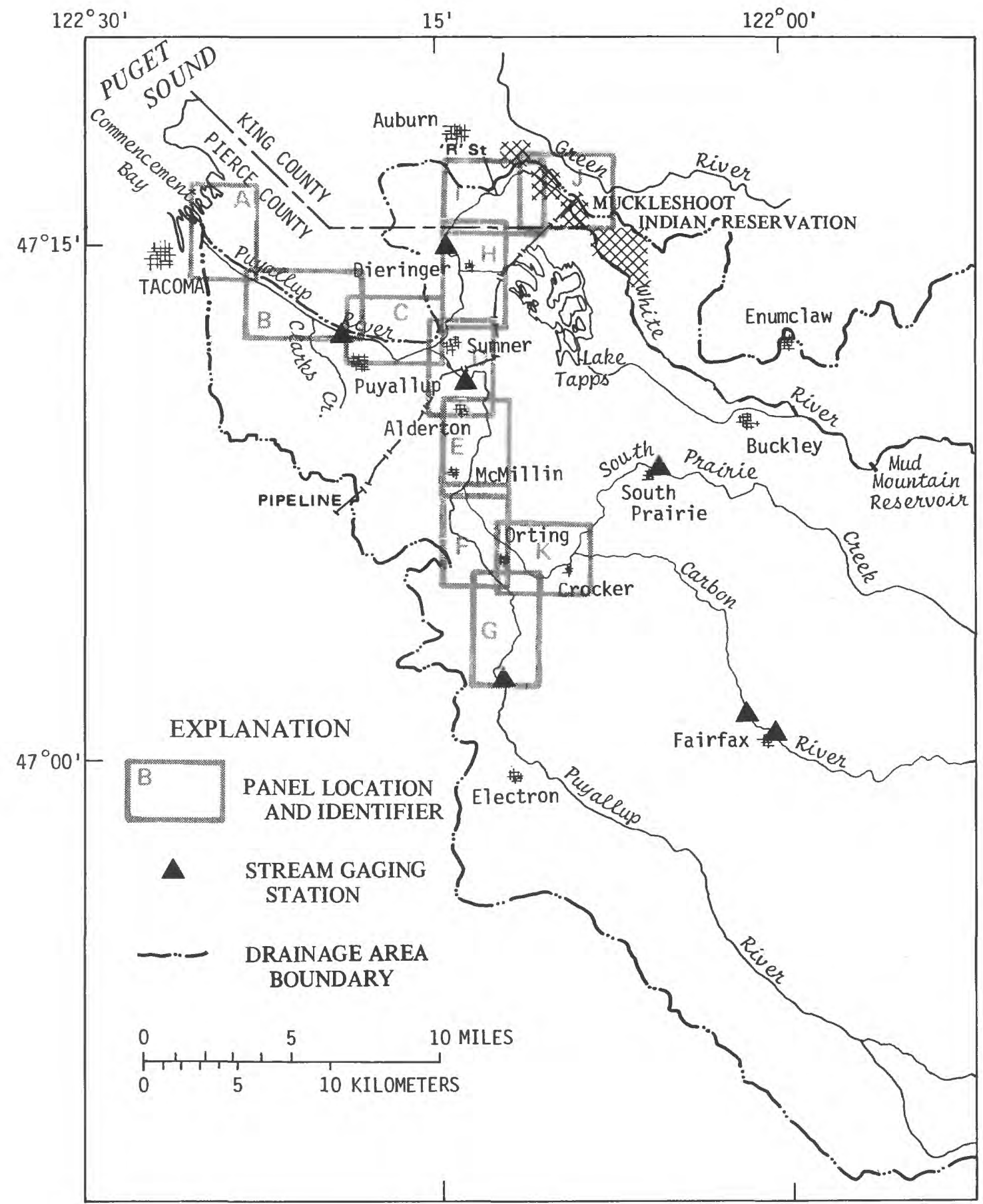

Figure Al.--Puyallup River drainage basin showing areas included in panels of figure A. 


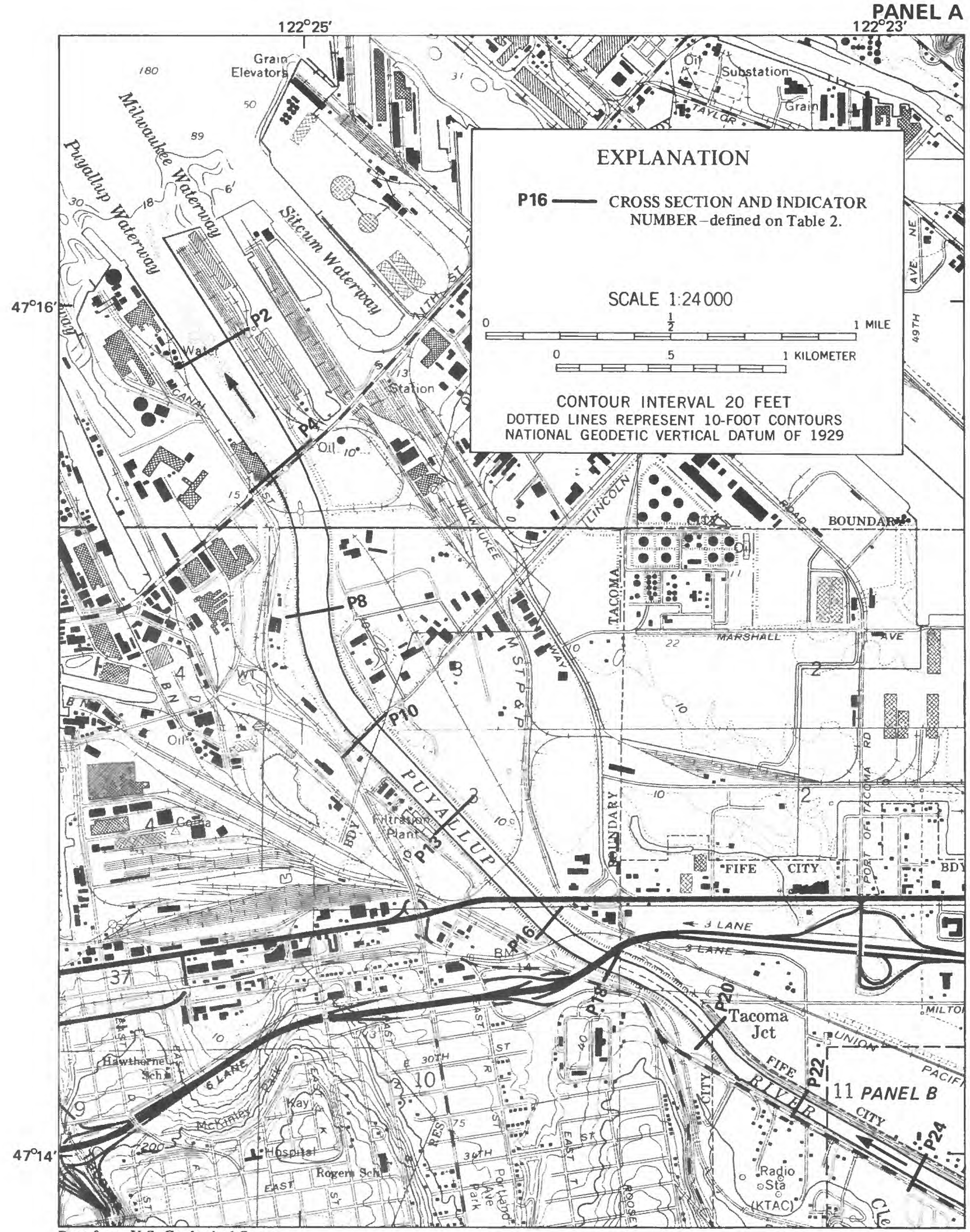

Base from U.S. Geological Survey

Tacoma North, 1961, photorevised 1981 and

Tacoma South, 1961, photorevised 1981

Figure A2.--Panels A through $\mathrm{K}$. Maps of river reaches showing locations of surveyed cross sections. 


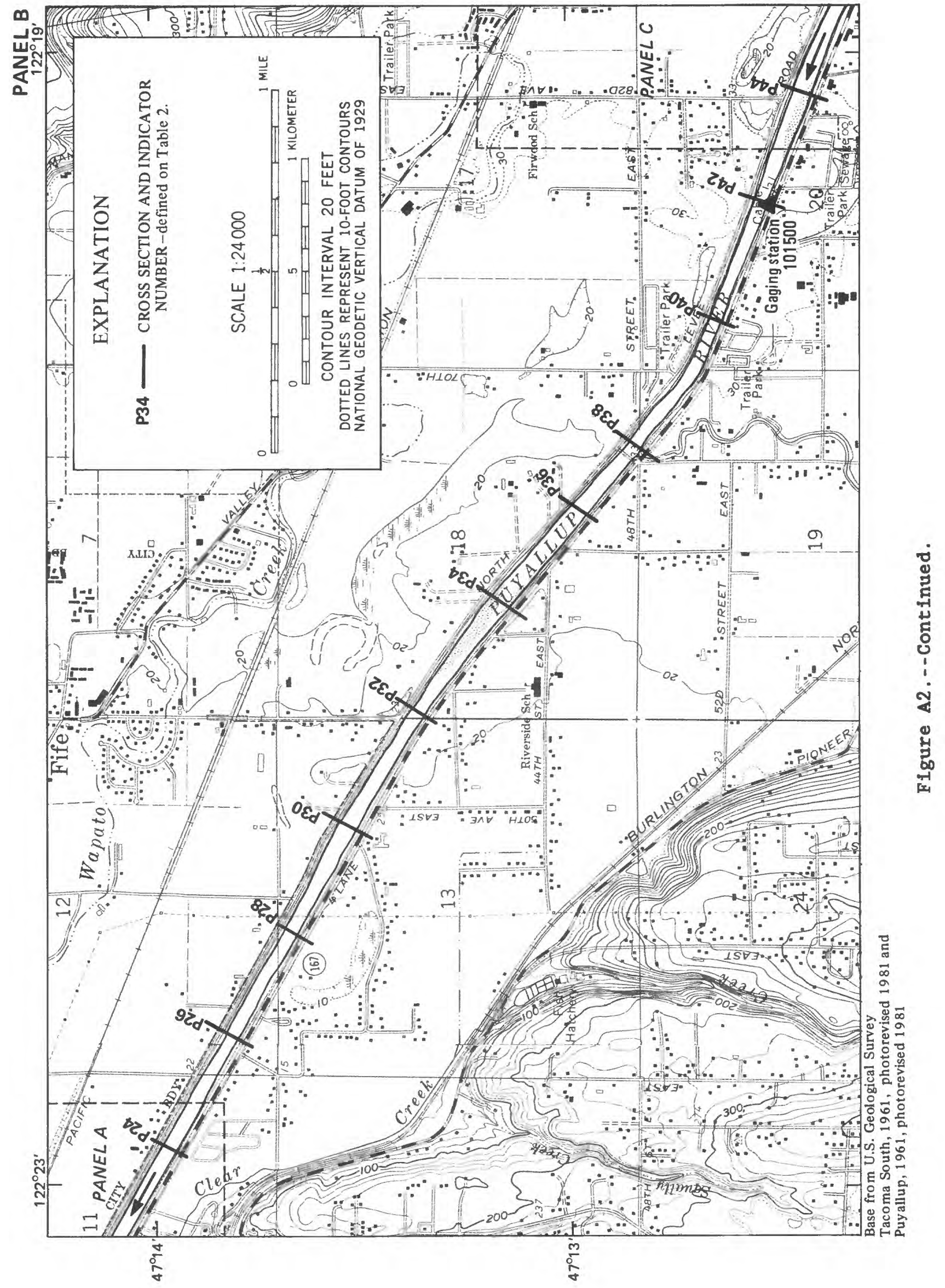



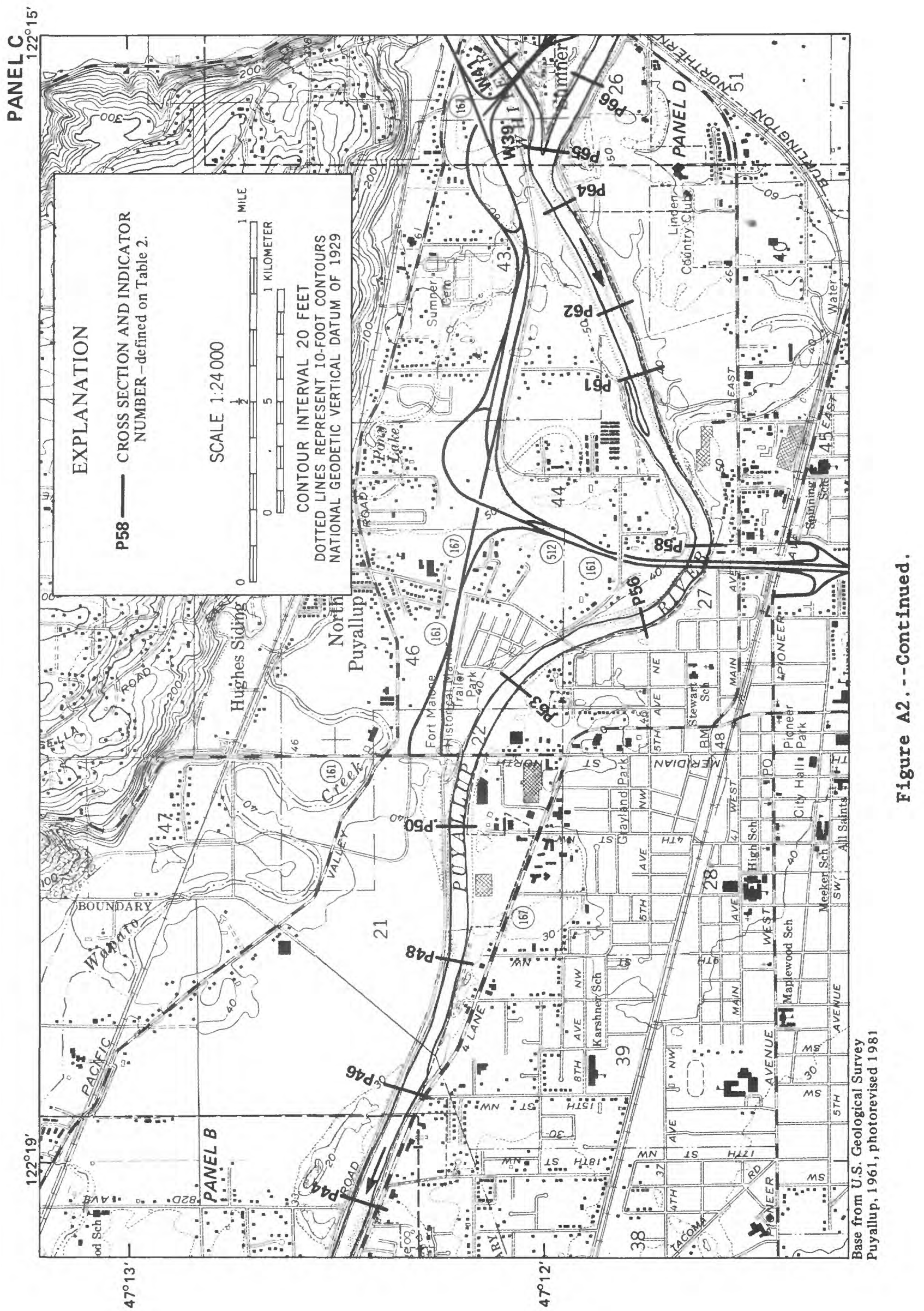


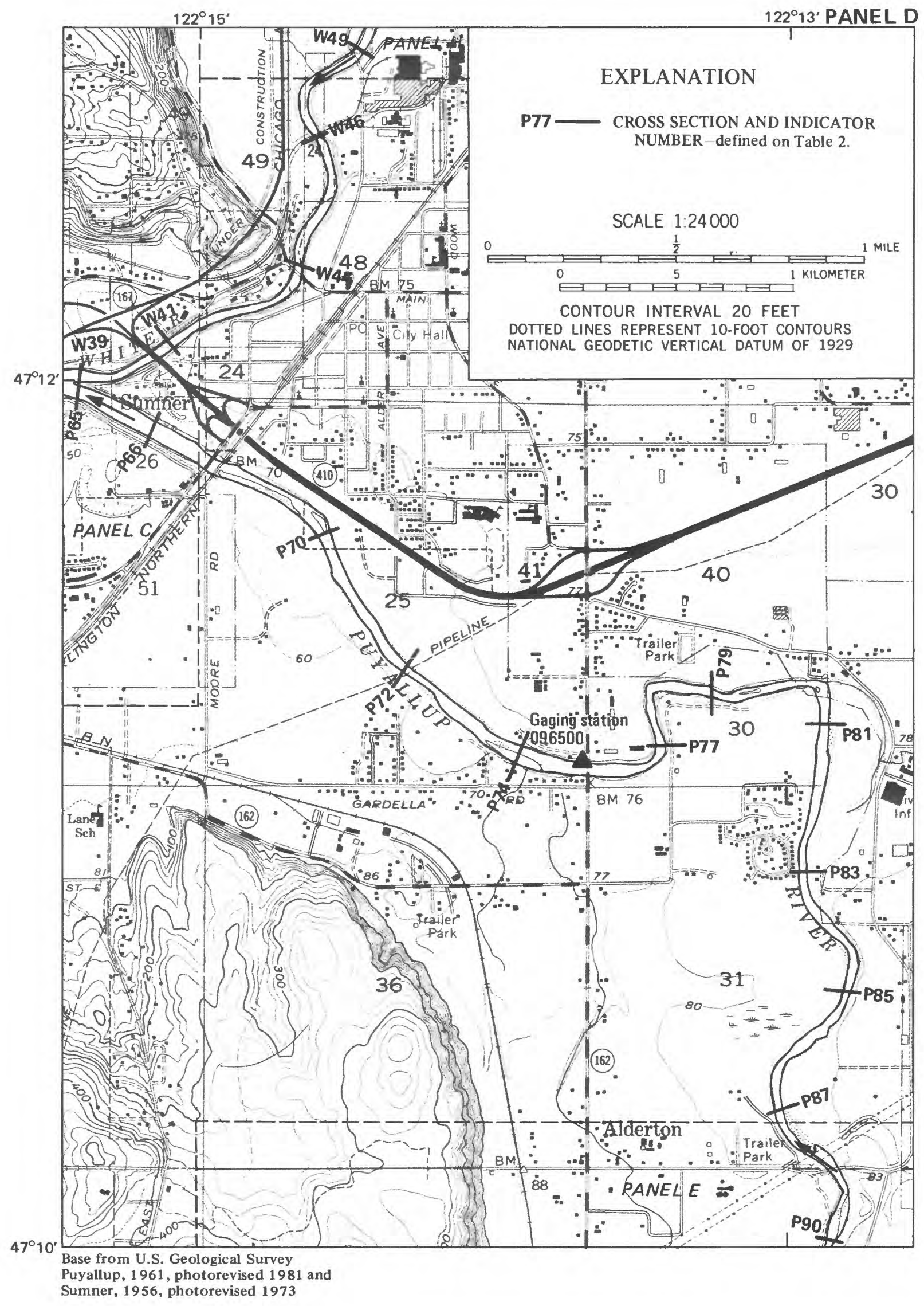

Figure A2.--Continued. 


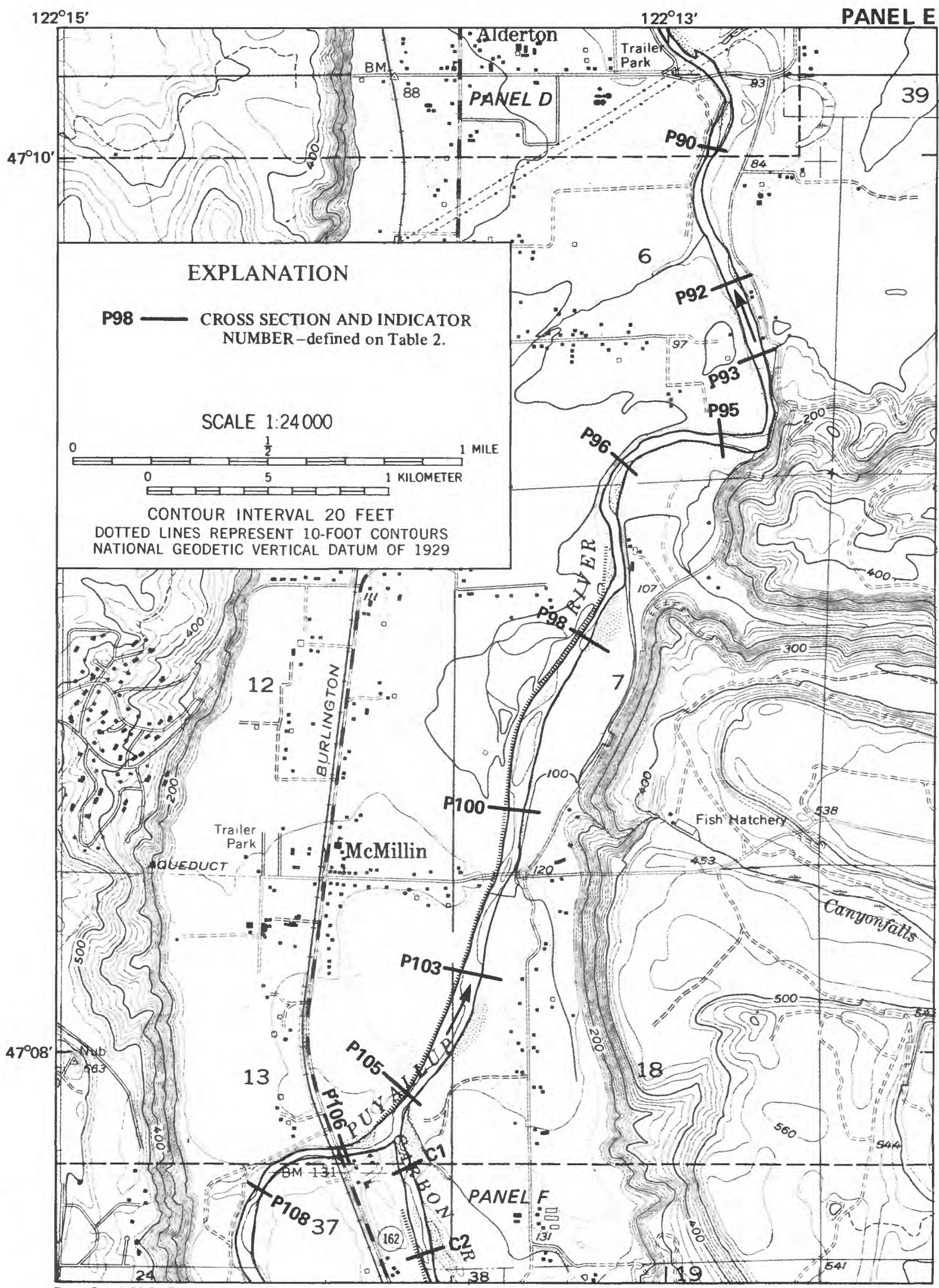

Base from U.S. Geological Survey Sumner, 1956, photorevised 1973

Figure A2.--Continued. 


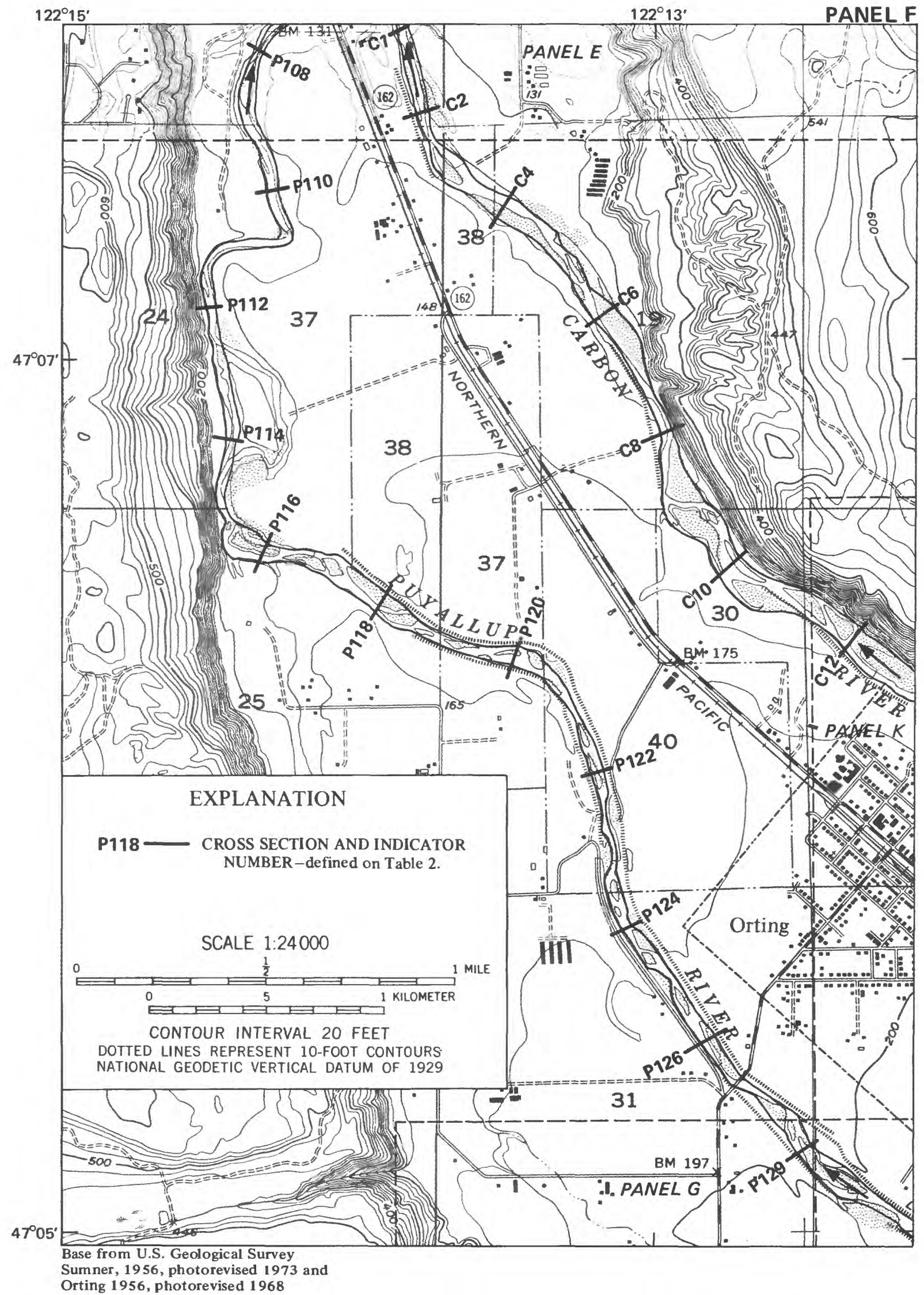

Figure A2.--Continued. 


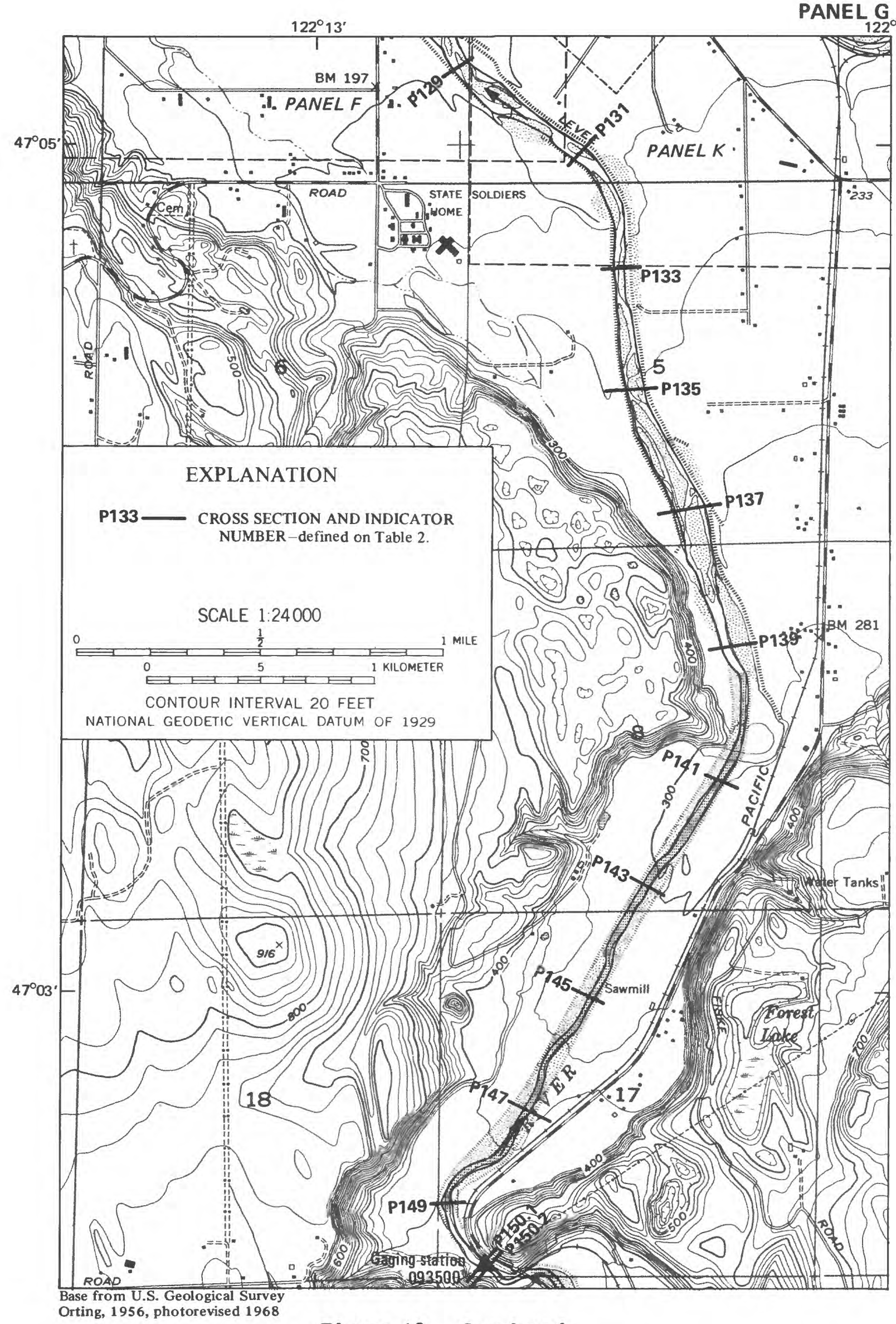

Figure A2.--Continued. 


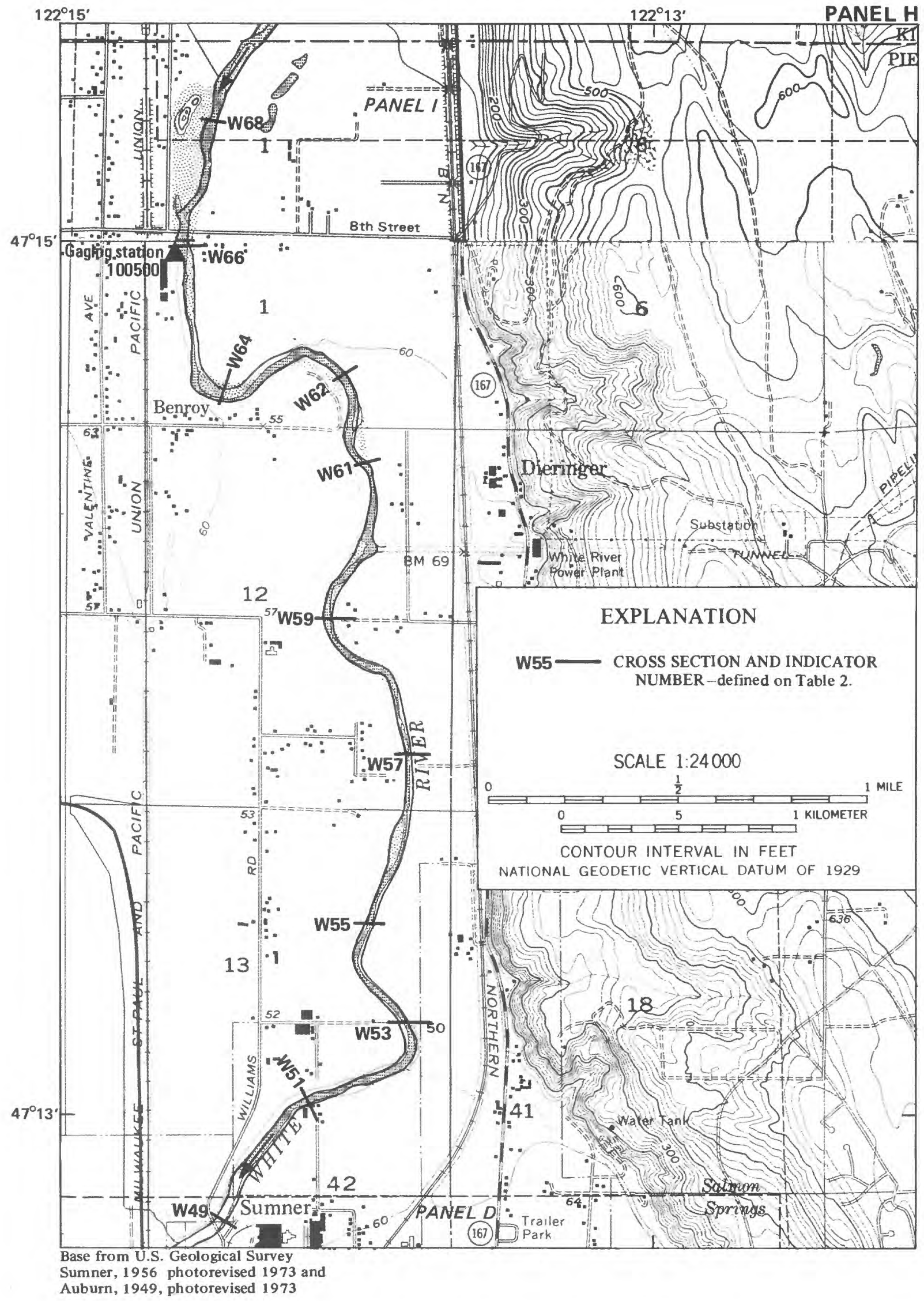

Figure A2,--Continued. 


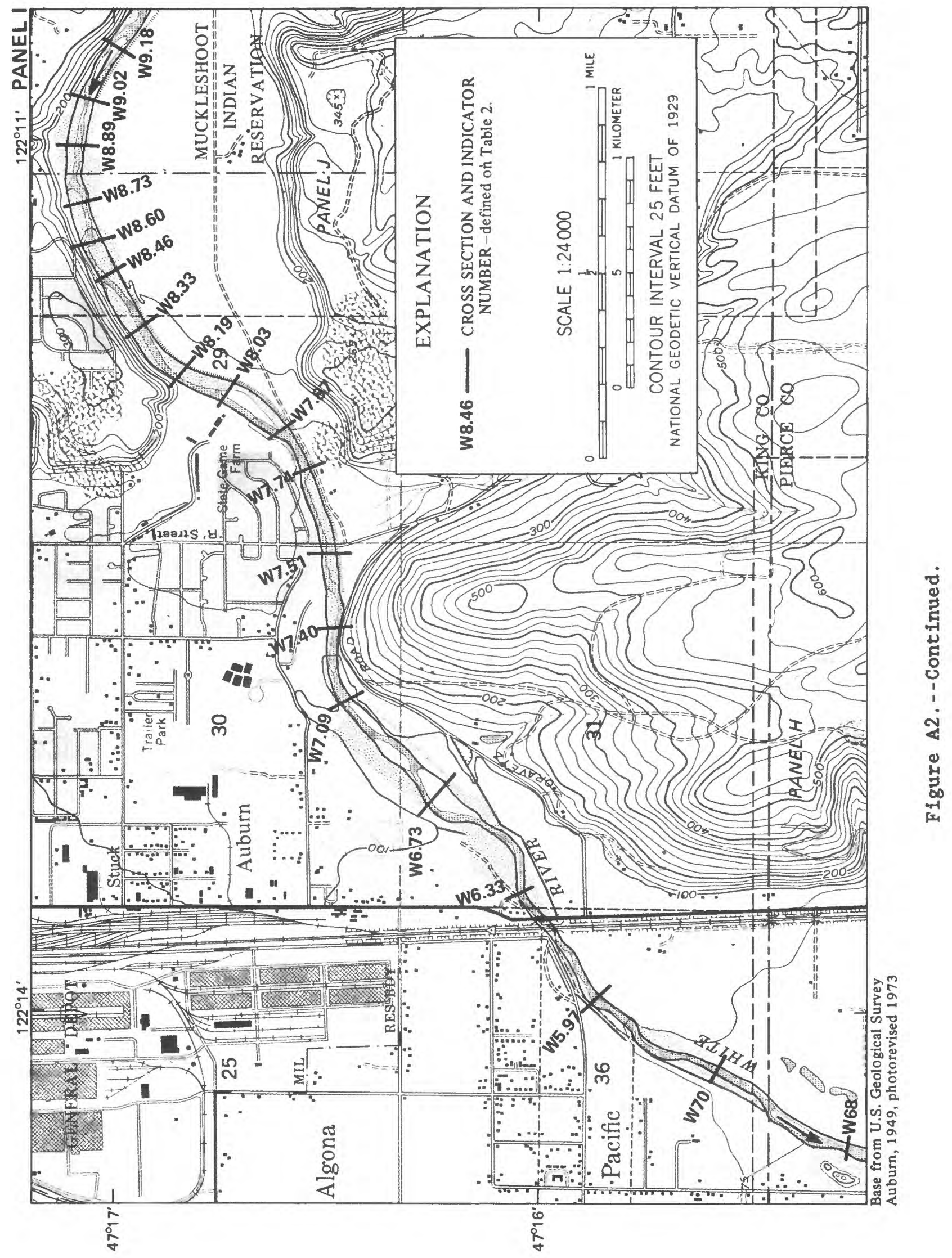




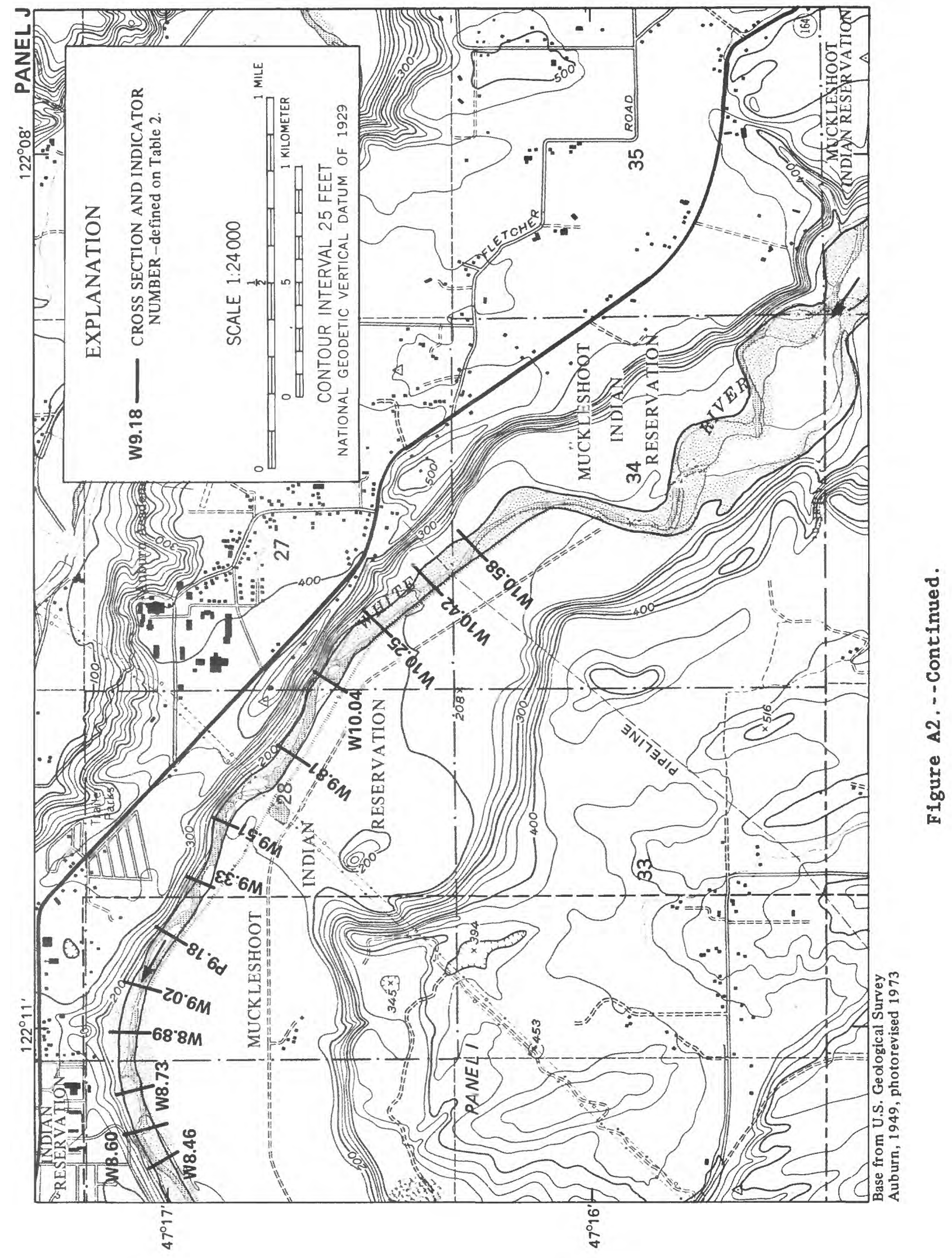




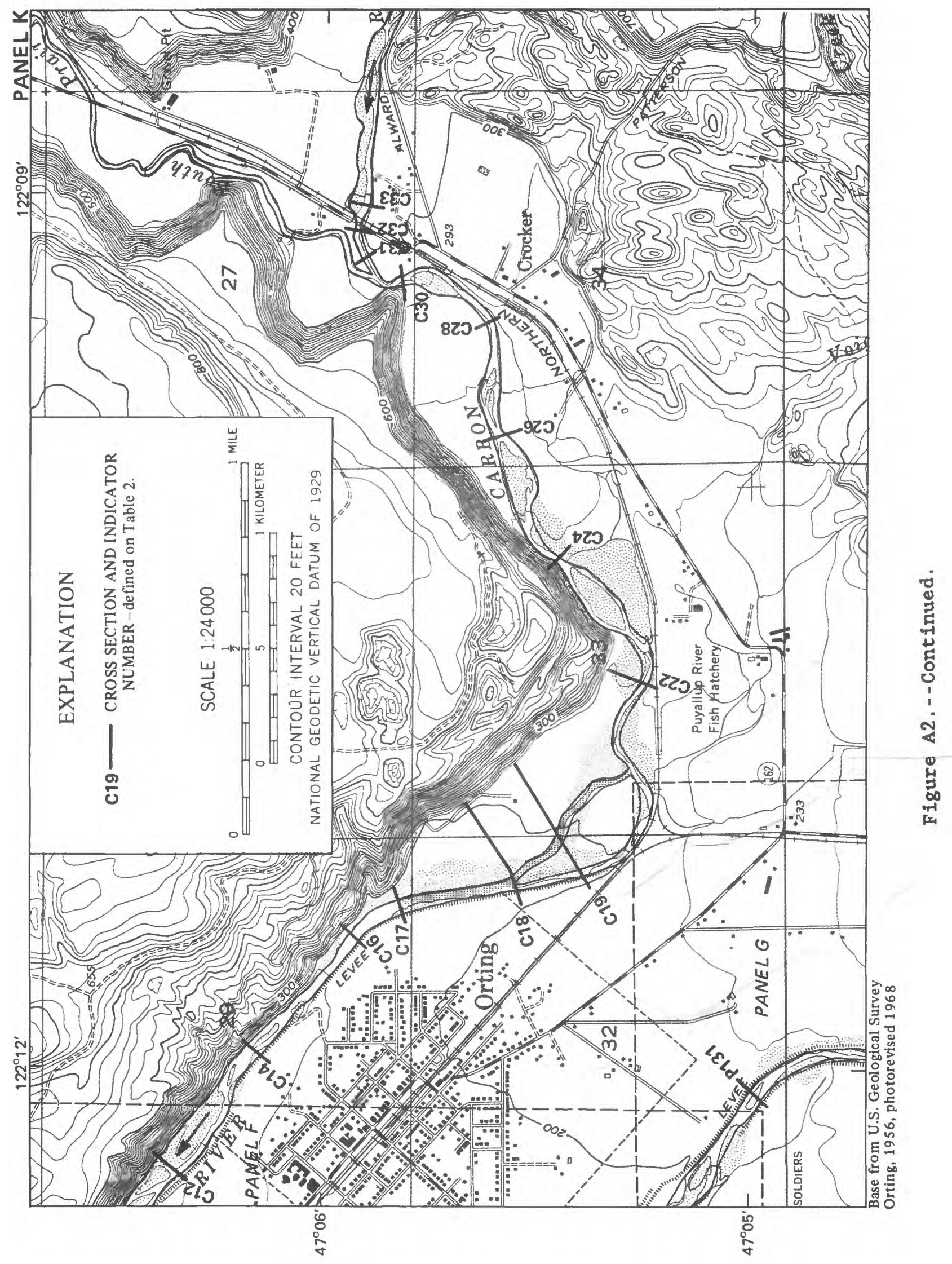



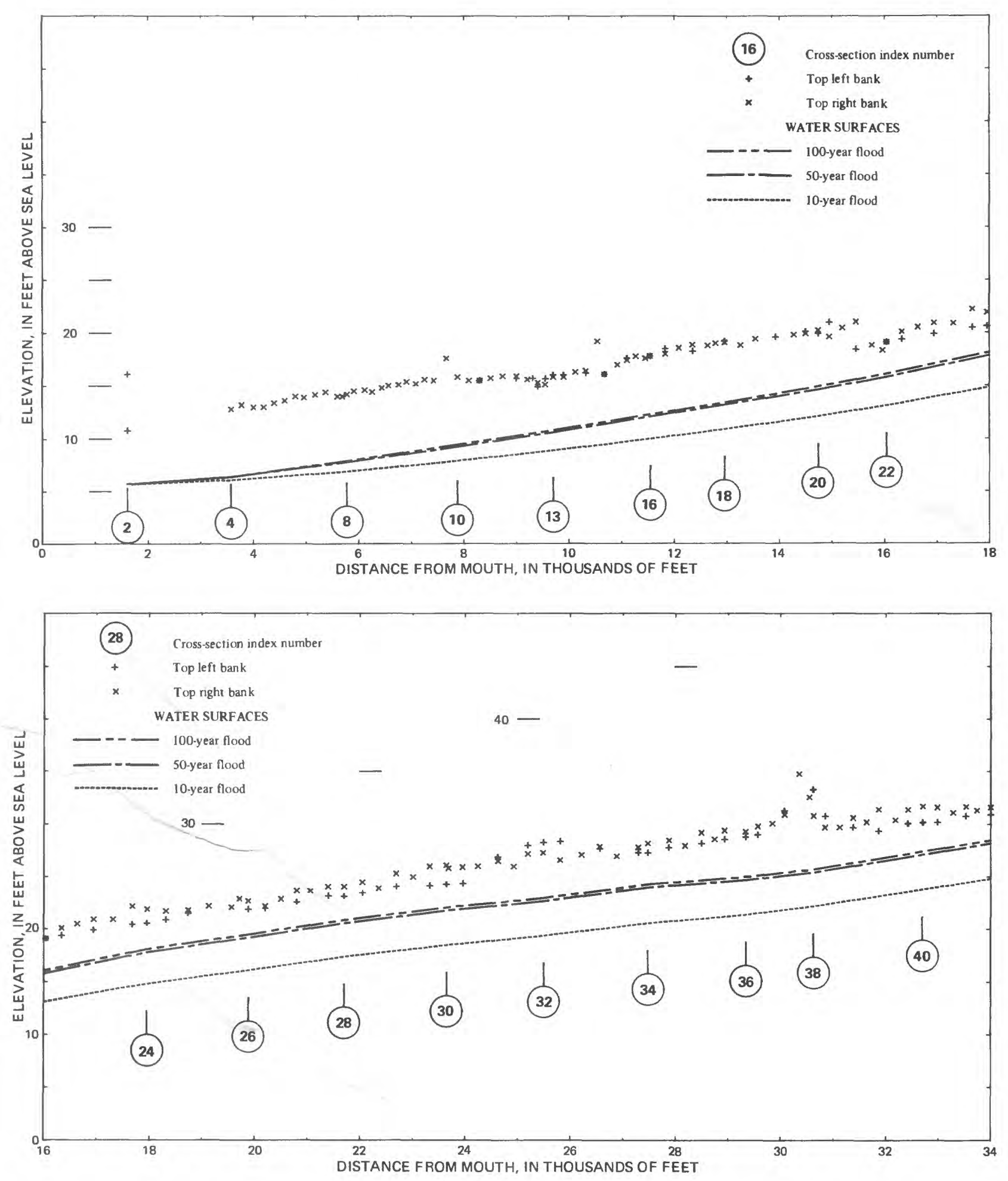

Figure A3.--Profiles of computed water-surface elevations for 10-, 50-, and 100-year floods, and of tops of banks or levees along the 1984 channel of the lower Puyallup River. 

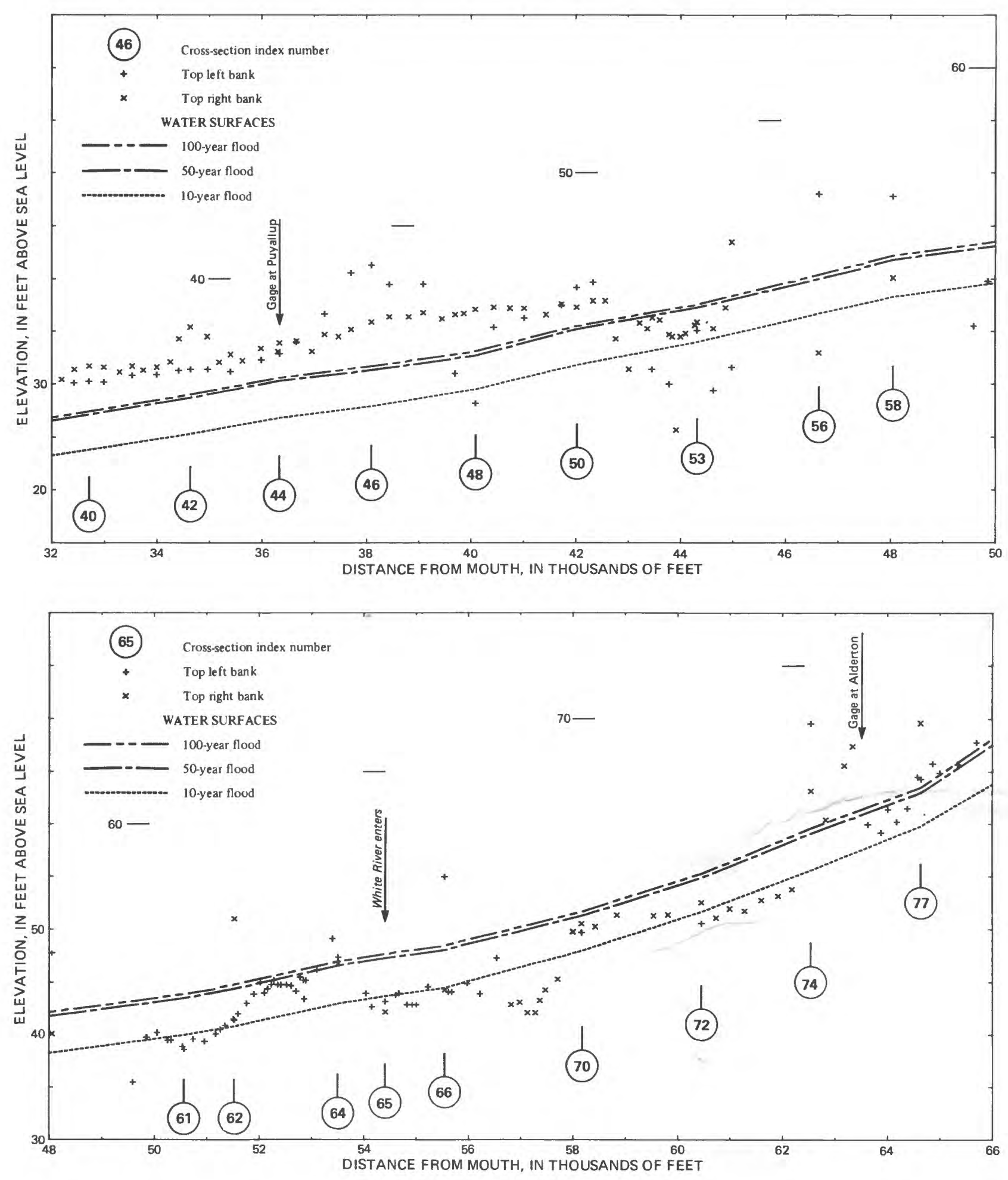

Figure A3,--Continued. 

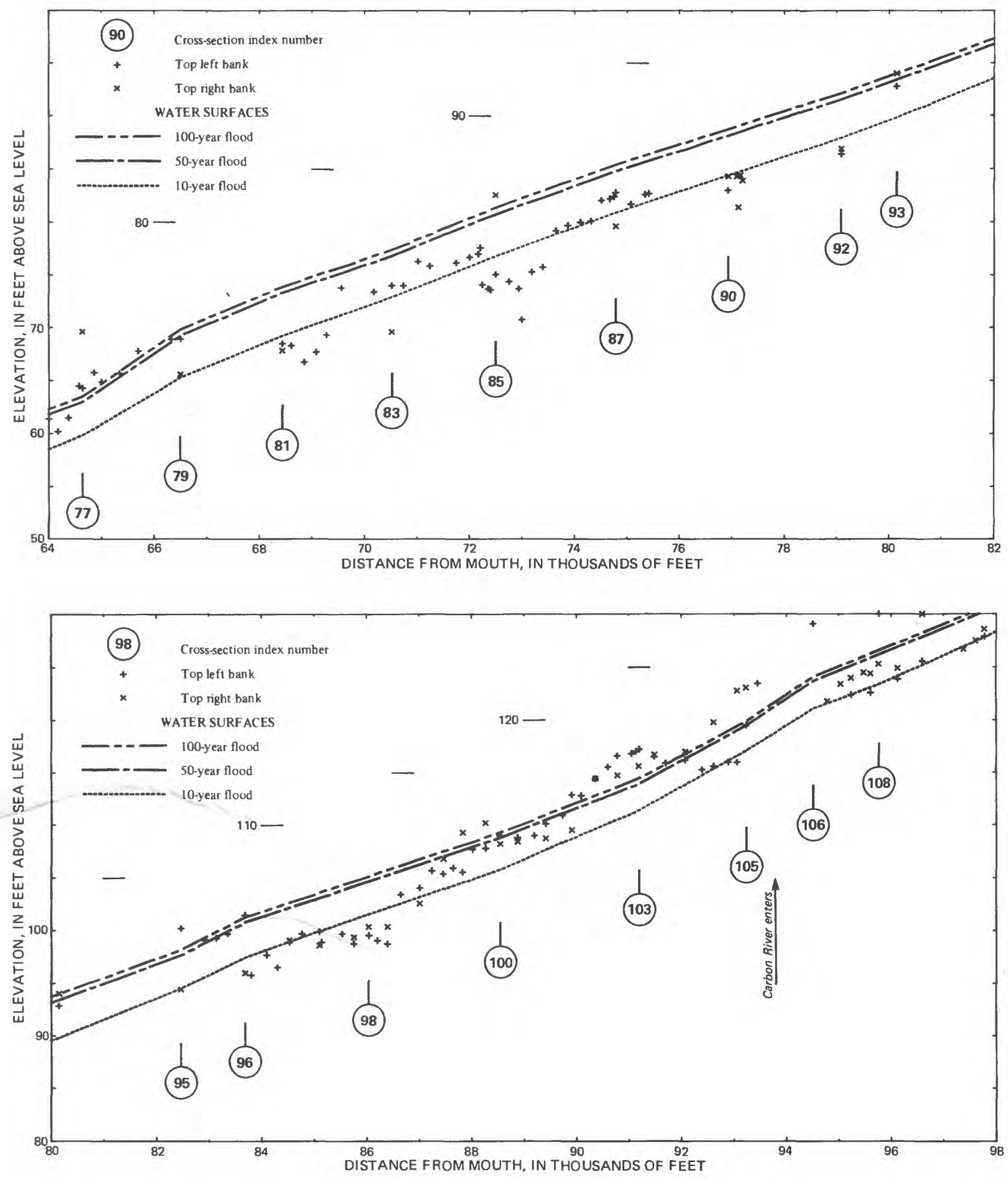

Figure A3.-.-Continued. 

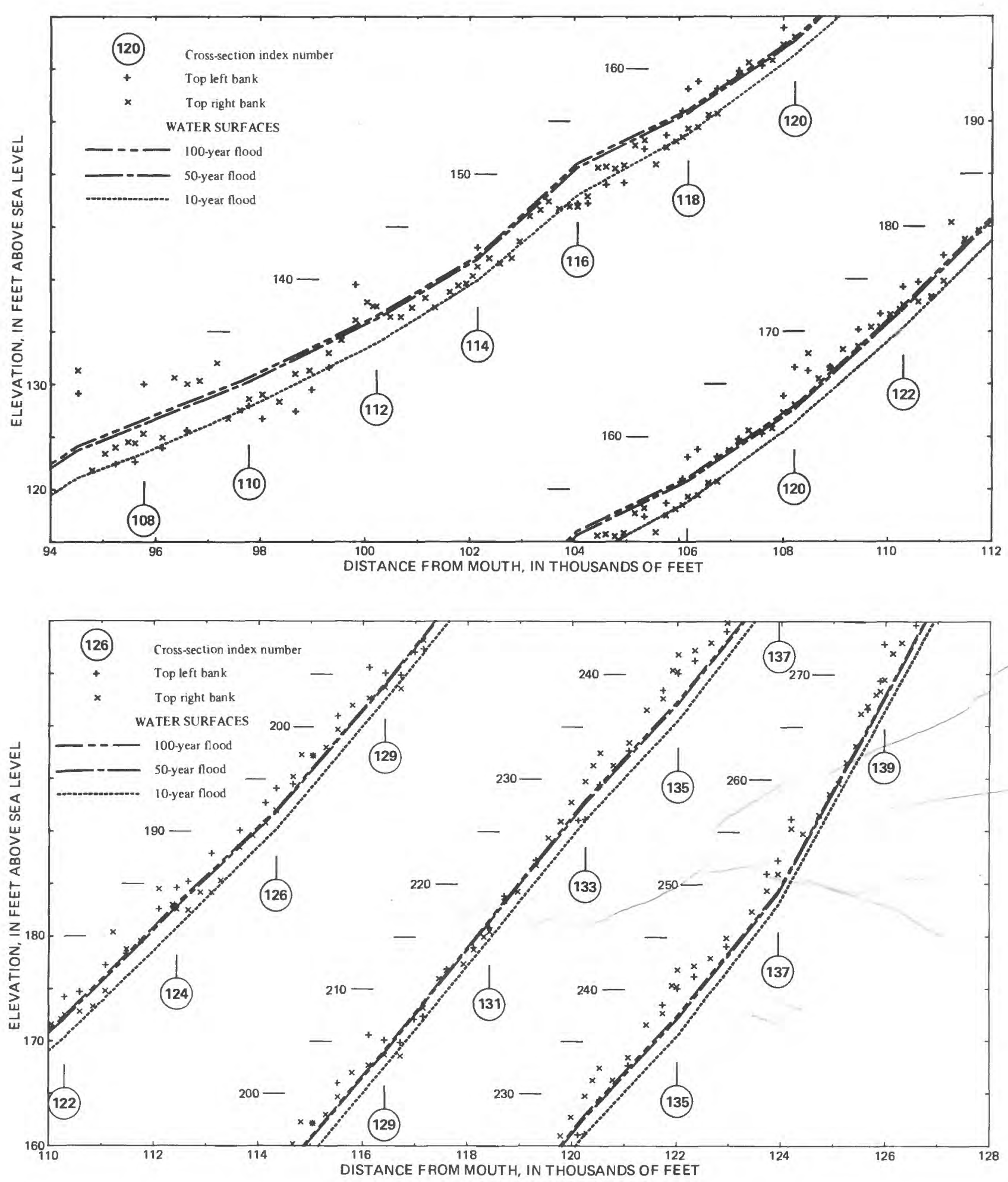

Figure A3.--Continued. 


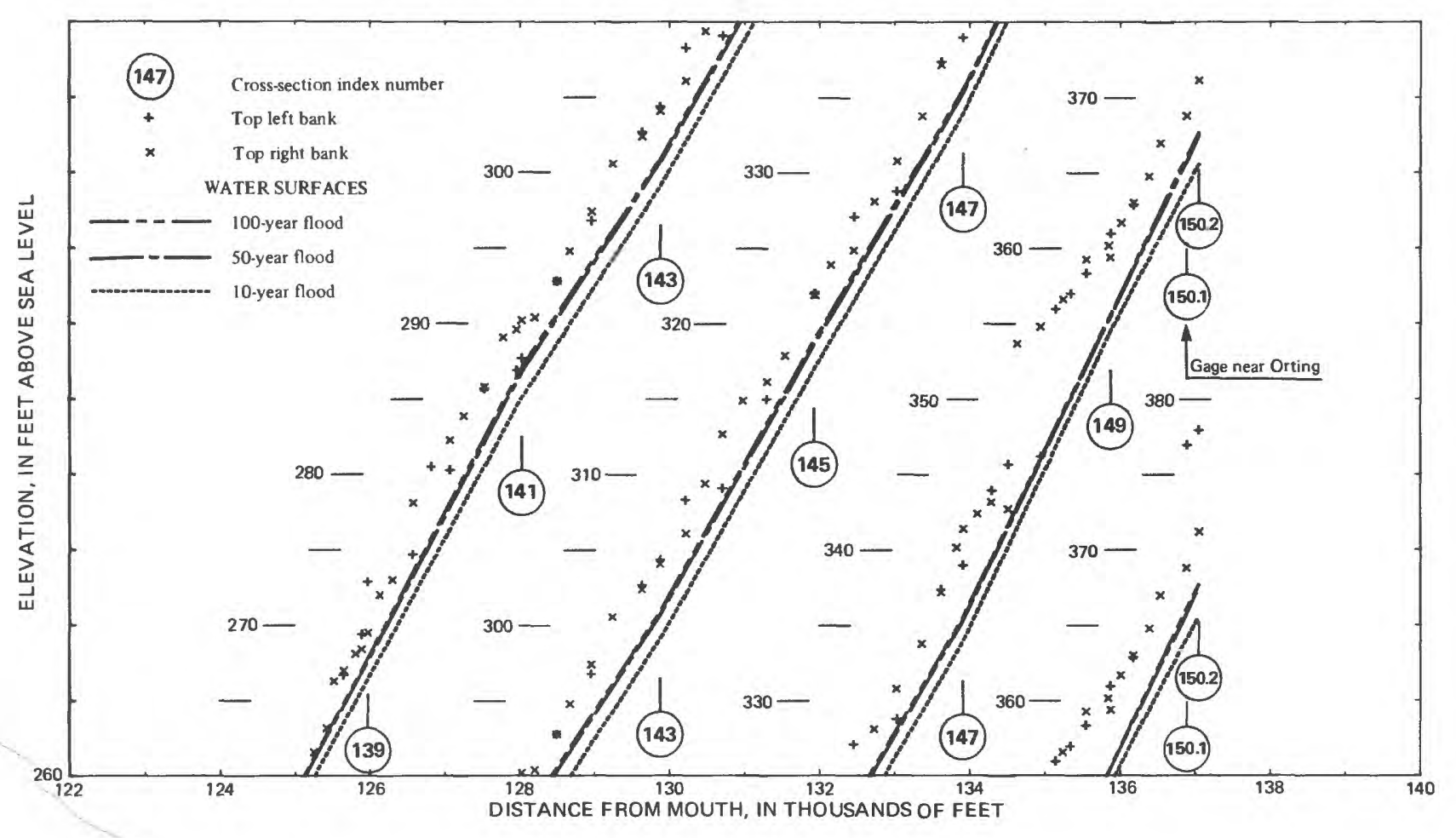

Figure A3.--Continued. 

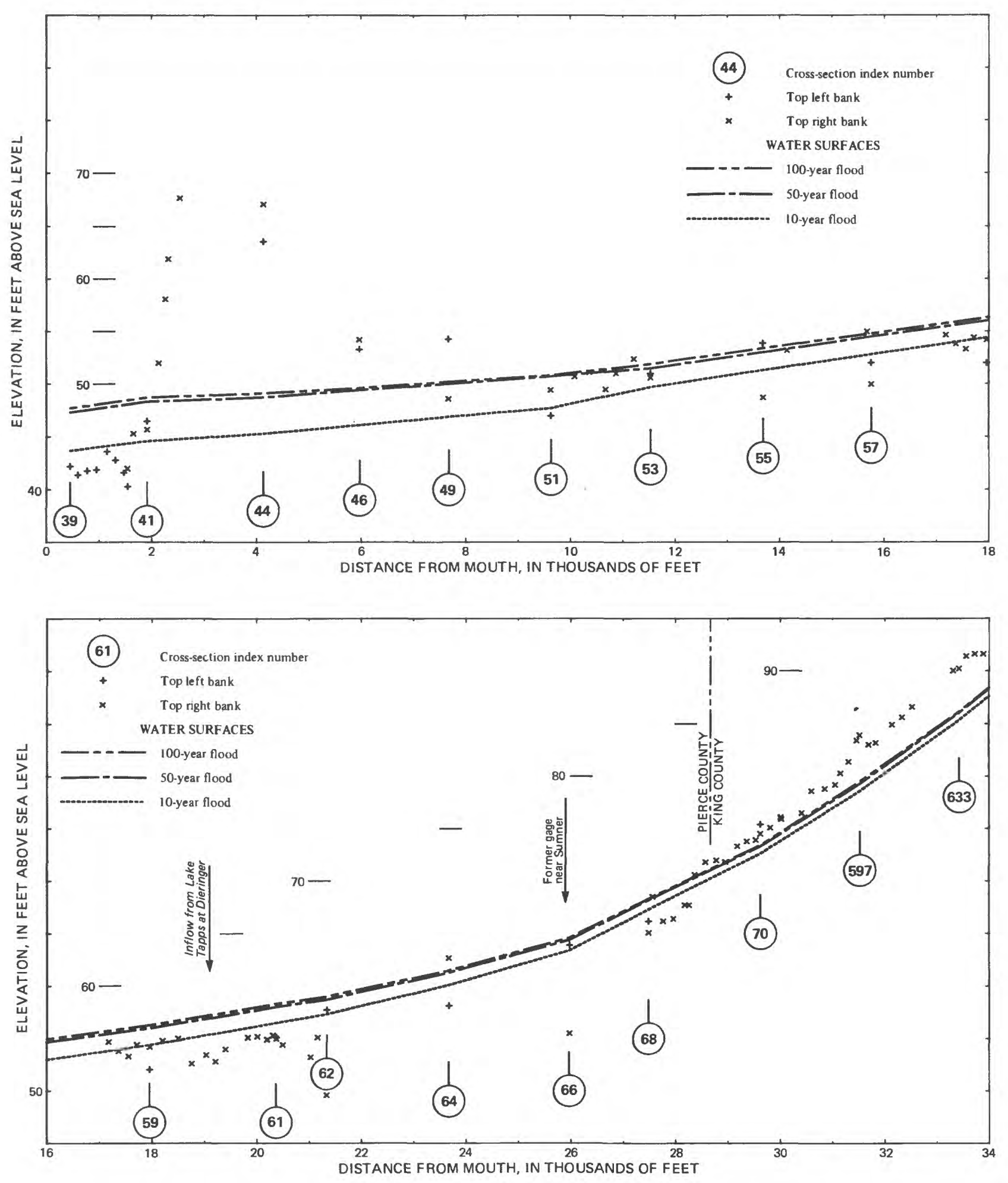

Figure A4.--Profiles of computed water-surface elevations for 10-, 50-, and 100-year floods, and of tops of banks or levees along the 1984 channel of the lower White River. 

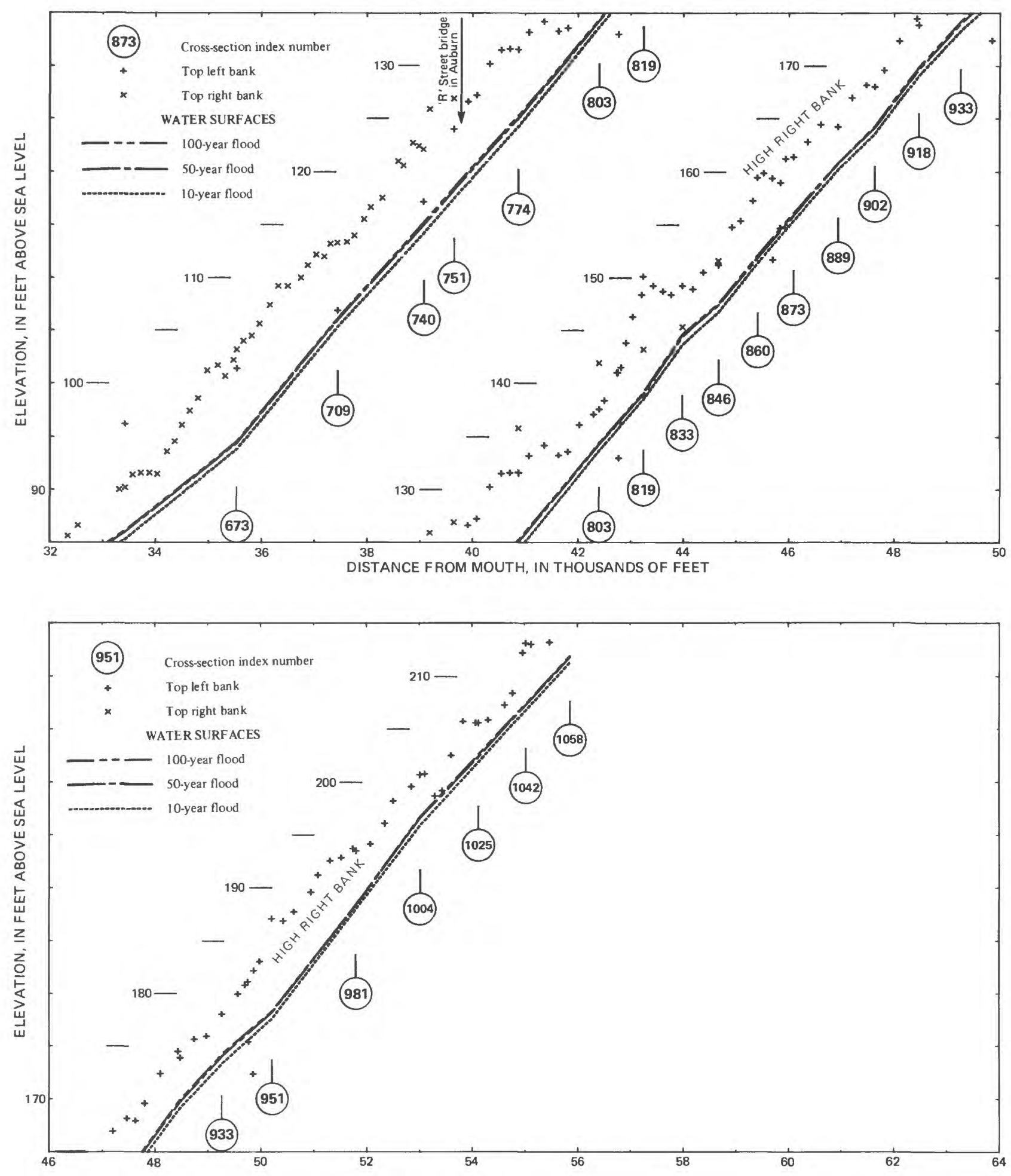

Figure A4.--Continued. 

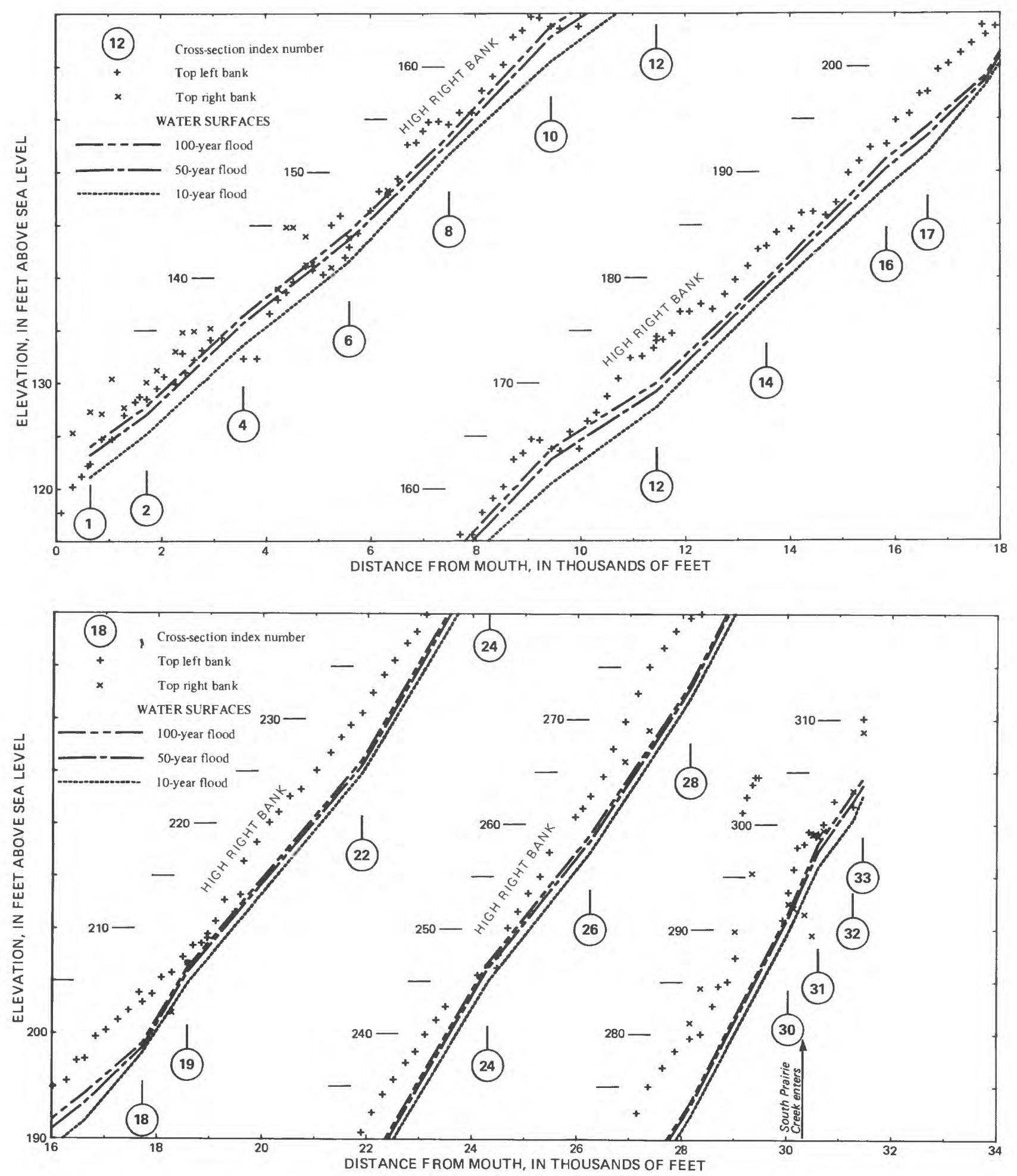

Figure A5.--Profiles of computed water-surface elevations for 10-, 50-, and 100-year floods, and of tops of banks or levees along the 1984 channel of the lower Carbon River. 